\title{
USO, APROPRIAÇÃO E EXPLORAÇÃO DO TERRITÓRIO: O CASO DE ITAÚNAS-ES
}

\author{
JUlia SALVAdOR MARTins \\ Licenciada em Geografia
}

Orientadora: Prof ${ }^{\mathrm{a}}$. Dr ${ }^{\mathrm{a}}$. SILVIA MARIA GUERRA MOLINA

Dissertação apresentada a Escola Superior de Agricultura "Luiz de Queiroz", Universidade de São Paulo, para obtenção do título de Mestre em Ecologia de Agroecossistemas.

P I R A C I C A B A

Estado de São Paulo - Brasil

Abril - 2005 
Dados Internacionais de Catalogação na Publicação (CIP) DIVISĀO DE BIBLIOTECA E DOCUMENTAÇĀO - ESALQ/USP

Martins, Julia Salvador

Uso, apropriaçāo e exploraçāo do território: o caso de Itaúnas - ES / Julia Salvador

Martins. - - Piracicaba, 2005.

136 p. : il.

Dissertaçāo (mestrado) - - Escola Superior de Agricultura Luiz de Queiroz, 2005.

Bibliografia.

1. Áreas de conservaçāo 2. Ecologia humana 3. Itaúnas 4. Proteçāo ambiental 5. Território Uso I. Título

$\operatorname{CDD} 301.31$

Termitida a copia total ou paral deste documento desde que citada a fonte- o autor 
Com saudades, a memória do meu avô Fernando, pelo exemplo de vida, onde buscou a humildade, a honestidade e a tranqüilidade.

Ao querido André, por todo incentivo, carinho, paciência e amor.

Ao meu companheiro e querido filho Pedro.

Dedico. 


\section{Agradecimentos}

À querida Silvia Maria Guerra Molina, pela confiança, carinho e respeito. Pelas suas orientações, por me apresentar os caminhos da Ecologia Humana e por compartilhar todos os momentos do trabalho. E principalmente pelo exemplo de vida, humildade e humanidade.

À professora Maria Elisa P. E. Garavello, que me mostrou os caminhos da Antropologia e a importância da alteridade.

Ao João Hoffel por toda sua atenção e dedicação, em suas sugestões para o trabalho.

À professora Magda Adelaide Lombardo que me incentivou desde a graduação, a trilhar pelos caminhos da pesquisa científica.

Aos colegas de laboratório e grupo de pesquisa em Ecologia Humana, agradeço a todos a oportunidade de trocar idéias e conhecimentos com vocês. Em especial amiga à Márcia, por sua amizade e por compartilhar comigo seus muitos conhecimentos e também àqueles, sobre os povos que vivem à beira mar.

À minha querida família, vó Wilma e ao meu irmão Eduardo, pelo amor e paciência na trama do cotidiano e por toda a ajuda durante o percorrer no curso de pós-graduação.

Às minhas amigas, irmãs, Silvia e Alice Peres, por toda amizade, todo carinho e incentivo a pesquisa. Pelos intensos momentos de conversa sobre o trabalho. E a Silvia por deixar sempre disponível os livros de sua biblioteca.

À Flavia Rossi pela sua amizade e por ter me apresentado a Vila de Itaúnas sob outro olhar.

À minha amiga Juliana, por toda a paciência do mundo em sempre me ouvir, em todos os momentos e por me mostrar o lado mais leve da vida.

À Claudia Rossi pela cordialidade e por dividir comigo importantes e felizes momentos do trabalho de campo.

Aos queridos D. Edith e Sr. João pelo carinho e dedicação. 
À todos da minha família sempre dispostos a me ajudar.

$\grave{A}$ todos meus muitos amigos, que ajudam a vida tornar mais divertida.

À Regina Freitas pela paciência, atenção e carinho.

À Eliana pela simpatia e atenção na correção das normas.

Em especial aos amigos e moradores de Itaúnas com quem aprendi muito sobre a vida e sobre a natureza. 


\section{SUMÁRIO}

Página

RESUMO

viii

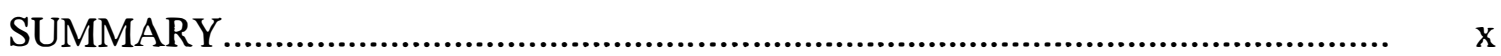

1 INTRODUÇÃO

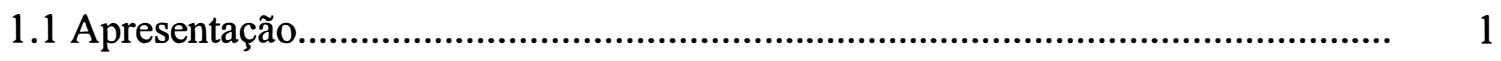

1.2 Contextualização histórico-espacial do problema da pesquisa............................. 3

1.3 Justificativa e importância da pesquisa................................................................. 6

1.4 Objetivos ............................................................................................ 8

2 REVISÃO DE LITERATURA.................................................................. 9

2.1 Populações tradicionais e pescadores artesanais...................................................... 9

2.2 Território: análise sobre os diferentes usos e interesses...................................... 14

2.3 Novas atividades econômicas: comunidades tradicionais e capitalismo............... 25

2.4 Fatores estressores relacionados a populações humanas...................................... 32

2.5 Estratégias adaptativas em populações humanas................................................... 34

2.5.1 Sistemas de parentesco e núcleos residenciais................................................. 39

2.5.2 Do conceito de território à noção de territorialidade.......................................... 42

3 METODOLOGIA.................................................................................. 48

3.1 Abordagem da pesquisa: qualitativa............................................................... 51

3.2 Procedimentos......................................................................................... 52

3.3 Técnicas de pesquisa instrumentais para a coleta de dados................................... 53

3.3.1 Trabalho de campo e observação participante................................................... 53

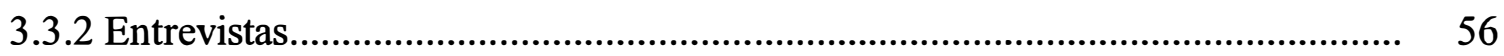

3.4 Análise e interpretação de dados...................................................................... 57 
3.5 Caracterização e discussão geográfica e histórica de Itaúnas................................. 58

3.5.1 Aspectos geográficos.................................................................................... 58

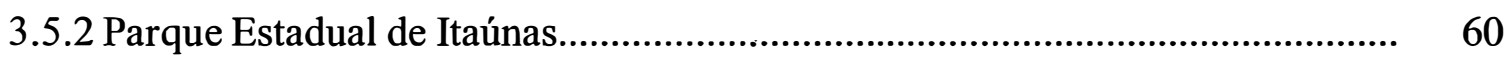

3.5.3 Plantações de eucalipto no município de Conceição da Barra-ES...................... 62

3.5.4 Os primeiros registros de Itaúnas............................................................... 64

3.5.5 Fragmentos de memórias: a Vila de Itaúnas sob a areia..................................... 65

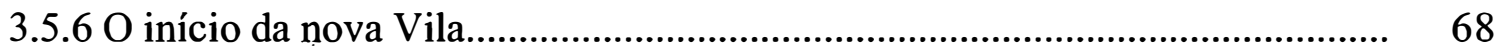

3.5.7 Infra-estrutura da Vila de Itaúnas atualmente.................................................. 69

3.5.8 Breve perfil dos moradores de Itaúnas............................................................. 70

4 RESULTADOS E DISCUSSÃO................................................................... 71

4.1 A fragmentação do território e os diferentes usos e apropriações......................... 71

4.2 Estratégias adaptativas.................................................................................. 86

4.3 A terra e o mar: territórios vividos e apropriados................................................. 95

4.4 Elementos da tradição e simbolismo: pesca extrativismo, festas e rituais............. 103

4.5 A questão do manejo e conservação do ambiente natural..................................... 111

5 CONCLUSÕES................................................................................... 114

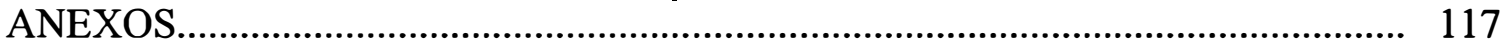

REFERÊNCIAS BIBLIOGRÁFICAS............................................................. 125 


\title{
USO, APROPRIAÇÃO E EXPLORAÇÃO DO TERRITÓRIO: O CASO DE ITAÚNAS-ES
}

\author{
Autora: JULIA SALVADOR MARTINS \\ Orientadora: Prof ${ }^{\mathrm{a}}$ SILVIA MARIA GUERRA MOLINA
}

\section{RESUMO}

A Vila de Itaúnas, distrito rural do município de Conceição da Barra - ES, apresenta um histórico relacionado a processos de sobreposição no uso do território, os quais são responsáveis por gerar interferências no modo de vida da população local e na complexa relação dessa com o ambiente. Isso vem ocorrendo principalmente em aspectos relacionados ao manejo e conservação de recursos naturais. A sobreposição no uso do território foi consubstanciada pela implantação em grande escala da monocultura de eucalipto, por empresas de celulose, pela Unidade de Conservação e pelo turismo. No novo cenário de territórios sobrepostos, os moradores diante da ausência de espaços para obtenção de recursos necessários à sua sobrevivência, passaram a adotar certos comportamentos, como resposta aos problemas impostos pelo ambiente natural e social. Face a esse contexto, essa pesquisa se propôs a analisar as estratégias adaptativas da população de Itaúnas, a partir da década de 70, tomando como base os modos de produção e modelos de subsistência e territorialidade, bem como as relações de parentesco e residência estabelecidas. Nesse estudo adotou-se por uma abordagem qualitativa e como método interpretativo, a complexidade, utilizando-se para coleta de 
dados, técnicas da antropologia, como observação participante e entrevistas. Por meio da realização desta pesquisa pode-se notar que na região de Itaúnas o processo de sobreposição no uso território, causou uma fragmentação do mesmo, interferindo na estrutura agrária da região. A lógica de apropriação do território passou da comunal para diversos interesses, tanto de preservação ambiental como de uso e exploração, causando alguns conflitos de ordem ecológica, social, cultural e econômica. Na ausência de espaço para obtenção de recursos necessários à sua sobrevivência, a população humana se vê forçada a acrescentar novas atividades de subsistência às antigas práticas culturais. Assim, como estratégia adaptativa, a população estudada vem buscando inserir-se em novas atividades econômicas, principalmente naquelas ligadas ao turismo. As mudanças no território vêm propiciando novas formas de relação dos moradores com o ambiente que os cercam. Este processo vem fazendo emergir territorialidades inéditas nesse ambiente. Observou-se em Itaúnas, a coexistência de territorialidades distintas que se concretizam por meio de usos diversos do território: comunal tradicional, empresarial, comercial e governamental. Com isso, a população local passa a criar e a incorporar novas concepções de uso, domínio e apropriação do território. Com relação à Unidade de Conservação, esta ainda está associada a uma relação de conflitos com os moradores locais, fruto do modelo sob o qual foi implantado. Em função disto, constatou-se algumas ameaças à preservação dos ecossistemas e à biodiversidade local. Observou-se também, que mesmo sofrendo interferências no seu modo de vida, a população humana de Itaúnas ainda conserva muitos dos saberes e apresenta algumas características associadas à tradição local, relevantes para sua sobrevivência. 


\title{
USE, APROPRIATION AND TERRITORY EXPLORATION: THE ITAUNAS CASE
}

\author{
Author: JULIA SALVADOR MARTINS \\ Adviser: Prof ${ }^{a} \mathrm{Dr}^{\mathrm{a}}$ SILVIA MARIA GUERRA MOLINA
}

\section{SUMMARY}

The Vila de Itaúnas, a rural district of Conceição da Barra county - ES, presents a historical precedent related to overlapping processes on the use of the territory, which are responsible by generate interferences on the local human population way of life, and on the complex relation of this population with the environment. This is occurring mainly in aspects related to the natural resources management and conservation. The overlapping in territory use was did by in great scale implanting of eucalyptus mono-culture, by the cellulose enterprises, by the Conservation Unit, and by the tourism. At the new overlapped territories scenery, the inhabitants in front of the absence of resources necessaries to their survival, start to adopt same behaviors as answers to the problems imposed by the natural and social environment. In face of this context, this research had as aim of analyses the Itaúnas human population fitting strategies, from the ' 70 , employing as base the stated way of production, and the subsistence models and the territoriality, as well as, the kinships and way of residence. In this study we adopted an qualitative approach, and as method of interpretation, the Complexity, using to the data collect, anthropological techniques, like participating observation and interviews. From this research we could notice that in the Itaúnas region 
the overlapping territory process was the responsible by the fragmentation of the territory, and has interfering on the agrary structure of that region. The logic of territory appropriation change from a communal one to attend on many interests, like that of environmental preservation, as the use and exploration, determining may conflicts of the ecological, social, cultural and economic orders. With the absence of the space to the necessary resources acquisition to their survival, this human population use to see itself forced to adds new subsistence activities on the former cultural practices. So, as fitting strategies, the human population studied has trying insert itself in new economic activities, mainly those associated to the tourism. The territorial changes have propitiating new way of relations between the inhabitants and their rounding environment. The process has doing emerges in this environment unprecedented territorialities. We could observe that in Itaúnas there is the co-existence of distinct realities which render themselves by the diverse uses of the territory: the communal traditional, enterprise, commercial, and the governmental. From this, the local human population stars to rear and incorporate new conceptions of use, control, and appropriation of the territory. In respect to the Conservation Unit, this still remain associated to one conflictive relation with the local inhabitants, which origin is the model on it was stated. From this, we could verify some risks to the local ecosystems and biodiversity. We could observe also, that same under interferences in its way of life, the Itaúnas human population still maintain many of its knowledge and presents some characteristics associated to the local tradition as relevant to its survive. 


\section{INTRODUÇÃO}

\subsection{Apresentação}

\footnotetext{
"Aquilo que os seres humanos têm em comum é a capacidade para se diferenciar-se uns dos outros".

François Laplantine
}

A finalidade dessa apresentação é discorrer sobre os caminhos que trilhei desde o meu primeiro contanto com o cenário da pesquisa, até chegar à idéia de realizar essa dissertação, a qual é fruto de intensos momentos de reflexão, muito se devendo ao entrecruzamento entre a teoria e a prática.

O primeiro contato que tive com a Vila de Itaúnas-ES, foi em janeiro do ano de 1995, em uma viagem de férias a convite de uma amiga. Partir para a viagem, significoume ir ao encontro de um local desconhecido e principalmente entrar em contato com pessoas diferentes.

Conhecer a Vila de Itaúnas, zona rural do município de Conceição da Barra, proporcionou-me apreciar os atrativos de belezas naturais e culturais e estimular minha percepção em relação aos hábitos e comportamentos da população humana local, que de certa forma, eram bem distintos do meu, que pertenço a uma sociedade urbano-industrial. Essas diferenças existentes entre sociedades humanas, que Laplantine (1999), chama de "variabilidade cultural", é responsável por tornar a humanidade plural. Sendo o mais interessante, a capacidade do ser humano mesmo pertencentes à mesma espécie, se expressar por meio de especificidades culturais (Laplantine, 1999).

No ano de 1995, iniciei o curso de graduação em Geografia na Universidade do Estado de São Paulo - UNESP, em Rio Claro. Nas férias do primeiro ano letivo, verão de 
1996, novamente fui visitar Itaúnas. Ainda neste ano, enquanto cursava a faculdade, tive a oportunidade de visitar outras vezes Itaúnas, inclusive em épocas fora de temporada. Ressalto, que ir para Itaúnas fora de temporada turística foi uma experiência diferente, pois possibilitou-me interagir com a população local, observar e participar da vida cotidiana, ouvir histórias sobre a antiga Vila, sobre o soterramento da mesma, perceber um pouco o contato da população com o ambiente etc.

Em Rio Claro, os conhecimentos que iam sendo adquiridos através do curso de Geografia, possibilitaram-me desenvolver uma observação mais crítica da realidade de Itaúnas e a cada visita meu olhar ficava mais focado e menos distraído. No contato mais próximo com a população local, fui percebendo as rápidas transformações no seu modo de vida em função da sobreposição do uso do território e do turismo.

As reflexões sobre o que observara em Itaúnas, despertaram-me inquietações. Dessa forma, pensei em unir minhas reflexões com os conhecimentos acadêmicos e de alguma forma estudar o processo dinâmico que estava presenciando e assim transcender a condição de mera turista e espectadora.

A idéia de estudar a relação da população local com o seu ambiente, foi se fortalecendo com o tempo, até quando pensei em realizar um projeto de mestrado que tratasse desse tema. A idéia se concretizou, quando em contato com a professora Silvia Molina, esta aceitou a minha proposta e então juntas amadurecemos a idéia e a transformamos em um projeto de pesquisa, posteriormente aceita no Programa de Pósgraduação Ecologia de Agroecossistemas da ESALQ-USP.

A realização desse trabalho é bastante significativa para mim, sendo que através deste tive a oportunidade de conhecer um pouco mais os moradores desse lugar e com eles aprender coisas muito significantes, como a fraternidade, a liberdade e a igualdade.

Com os moradores de Itaúnas tive também a oportunidade de aprender muito sobre seu modo de vida e a relação com o ambiente. Dessa forma, só pude pensar neles, sob o ângulo do afeto, do humanismo.

Acredito, que de alguma forma, com esse trabalho, analisando o caso de Itaúnas, estou contribuindo com informações para o entendimento, reflexões e discussões sobre o processo de mudança que a população local vem sofrendo em seu território e no seu 
modo de vida. Do mesmo modo, acredito que as informações deste trabalho, possam contribuir para a discussão acerca da problemática de países em desenvolvimento, que envolve populações locais e a questão do acesso à terra.

\subsection{Contextualização histórico - espacial do problema da pesquisa}

A Vila de Itaúnas, distrito rural do município de Conceição da Barra-ES, apresenta um histórico relacionado a processos de sobreposição no uso do território, os quais são responsáveis por modificarem a configuração espacial da Vila e o modo de vida da população local, incluindo as atividades de subsistência.

Até meados do século $\mathrm{XX}$, os antigos moradores de Itaúnas, viviam em um território cercado por floresta, mar, brejos, lagoas e cursos d'água. Nesse ambiente de alta diversidade de recursos, a população local desenvolvia um modo de vida considerado tradicional, baseado no uso comunal e extrativista do território e dos recursos naturais. Os arranjos de posse do território e o acesso aos recursos eram estruturados através de regras implícitas, estabelecidas de acordo com uma lógica interna do grupo e estendida por uma teia de relação de parentesco, de compadrio, de ajuda mútua, que privilegiavam a solidariedade e a cooperação no grupo (Ferreira, 2002).

No território de uso comum, a população humana local manejava os recursos do ambiente natural e supria grande parte das necessidades de subsistência, obtendo água, peixes, carnes, frutos, madeira, cipó, raízes e ervas medicinais (Ferreira, 2002).

A pesca era uma das atividades de subsistência mais importantes da população da Vila antiga de Itaúnas. Conforme relata Ferreira (2002), esta atividade era realizada em canoas a remo, tanto no rio, como no mar.

As canoas eram esculpidas num único tronco das centenárias árvores nobres da floresta tropical e a tecnologia utilizada para a pesca era simples, o que caraterizava os indivíduos dessa população, como pescadores artesanais. Os moradores também realizavam a produção de farinha de mandioca e segundo Rebello \& Foëger (2002), esta era comercializada num regime de troca, sendo negociada por sal, tecidos, fumo e artigos de armarinho. 
A partir do início século $\mathrm{XX}$, os moradores de Itaúnas passaram a conviver com o processo de perda e transformação do território de uso comum, para outros tipos de propriedade como a estatal (parque estadual) e a privada (agroindústria de celulose) e também a conviver com novos estressores de caráter físico e cultural.

$\mathrm{O}$ primeiro tipo de apropriação se efetua no início do século $\mathrm{XX}$, quando a exuberante Mata Atlântica do Espírito Santo, passa a ser explorada em larga escala por um grupo de madeireiros, em busca de madeira-de-lei. A primeira região a ser explorada no Estado correspondeu à área que circunda a bacia hidrográfica do rio Itaúnas. Esse rio, nesse contexto, passa a ser apropriado e utilizado como via de transporte e escoamento da extração por madeireiras (Ferreira, 2002 e Rebello \& Foëger, 2002).

Um pouco mais tarde, na década de 50, a retirada da vegetação original e a areia levada pelos ventos alísios, sistema de ventos tropicais que sopram do leste em direção ao equador, predominantes na região, propiciam o início do processo de soterramento da antiga Vila de Itaúnas. Toda a antiga organização espacial da população desaparece totalmente na década de 70 , cedendo lugar às dunas móveis. Os moradores então, são forçados a se mudar para o outro lado da margem do rio e a construir neste local uma nova Vila (Petroff, 2003).

O ciclo de exploração da madeira no norte capixaba, iniciado nos anos 20 , se acentua na década de 70, com implantação da monocultura de eucalipto da Empresa Aracruz Celulose, incentivada pelo Estado através do II Plano Nacional de Desenvolvimento. Esse tipo de apropriação e exploração do território, além da desapropriação do território comunal, gera impactos socioambientais em detrimento do ambiente. Ou seja, o desmatamento da floresta, a retirada de matas ciliares, o uso intensivo de agroquímicos, entre outros fatores impactantes, levam à redução da diversidade biológica local o que contribuiu para a desestruturação do modo de vida da população local.

No ano de 1986, as dunas são tombadas pelo Estado como Patrimônio Histórico, Paisagístico e Cultural, por abrigar sítios arqueológicos. As dunas, somadas às outras belezas naturais como praias, rio e alagados, e às características culturais da comunidade, passaram a atrair um incipiente e ainda pacato movimento turístico na década de 80 . 
Uma outra forma de interferência direta do Estado sobre a privatização do território comunal de Itaúnas, se processou no ano de 1991, com a criação do Parque Estadual de Itaúnas (PEI) - Unidade de Proteção Integral efetivada pela Secretaria de Estado para Assuntos do Meio Ambiente (SEAMA-ES). As diretrizes do PEI implicaram na proibição do uso e manejo dos recursos naturais pela população tradicional, na área demarcada pelo Parque. Ou seja, foram proibidos a caça, o roçado, a pesca no rio, a extração de lenha, de ervas e cipós medicinais, a coleta de frutos, entre outras práticas da população local.

Um outro tipo de estressor começa a atuar a partir do final da década de 90, através do crescimento acelerado do turismo de massa e da juventude ${ }^{1}$. Um fato que impulsionou esse último tipo de turismo, foi a divulgação ao nível nacional, pelos meios de comunicação de massa, da tradição do forró local. Este tipo de atividade acarretou alterações na estrutura da Vila e problemas relacionados aos novos valores culturais trazidos pelos turistas e absorvidos principalmente pelos indivíduos mais jovens.

Em Itaúnas existem atualmente mais de 50 pousadas e 63 estabelecimentos comerciais (a maioria não pertence aos habitantes nativos), que passam a absorver grande parte da mão-de-obra local. Em período de férias o número de turistas chega a cerca de 39.000 , sendo que a população local não passa de 1.500 .

Toda a transformação espacial consubstanciada pelo processo de sobreposição no uso do território, bem como os estressores ocorridos em Itaúnas, implicaram em mudanças significativas nas relações de posse, apropriação e uso do território. Com isso foram alterados também importantes aspectos do modo de vida da população local.

No novo cenário de territórios sobrepostos, com a ausência de espaços para obtenção de recursos necessários à sua sobrevivência, os moradores de Itaúnas passaram a adotar certos comportamentos, como resposta aos problemas impostos pelo ambiente natural e social.

\footnotetext{
${ }^{1}$ Definido como turismo praticado por jovens estudantes; trata-se de um público alegre, pouco exigente e com capacidade média de consumo, em geral atraídos por locais que de belezas naturais e que ofereçam divertimentos noturnos. Ao retornar para casa narram com entusiasmo os acontecimentos e acabam motivando outras pessoas a visitarem o local (Giaretta, 2002).
} 
Face a esse contexto, esta pesquisa se propõe a analisar as estratégias adaptativas dos moradores locais nos aspectos que se referem aos modos de produção e modelos de subsistência e à territorialidade bem como, às relações de parentesco e residência associadas àqueles.

Ainda neste trabalho, pretende-se compreender as possíveis interferências de todo esse processo, no modo de vida da população humana e na sua interação com o ambiente.

\subsection{Justificativa e importância da pesquisa}

A complexidade dos problemas socioambientais da Vila de Itaúnas, advindos do processo de sobreposição no uso do território, indicam a necessidade da realização de estudos na área em questão, que contemplem análises interdisciplinares, englobando nas suas discussões, as dimensões ecológica, histórica, cultural e política.

Conforme relata Diegues (1996a), as questões ecológicas, sobretudo aquelas decorrentes das atividades humanas sobre o meio ambiente, estão entre os termos modernos que exigem uma abordagem interdisciplinar. Nesse sentido, esses estudos exigem interfaces com outras ciências, tanto naturais como sociais.

Para Morin (2001), o objetivo da ciência ecológica é estudar cada vez mais os problemas da biosfera no seu conjunto, em função da multiplicação das degradações e poluições em todos os continentes do planeta Terra.

Os estudos de Ecologia Humana segundo Begossi (2004), são apropriados para entender as interações entre a população humana e os recursos vegetais e aquáticos. Sendo o contato direto de populações humanas, a observação diária desses recursos e a dependência econômica com relação a esses, considerados relações ecológicas em seu sentido estrito.

O objetivo principal da Ecologia Humana é analisar o uso dos recursos com o intuito de entender a interação dessas populações com ambiente, além de buscar entender os processo adaptativos, preocupando-se com os meios pelos quais essas populações se mantêm e se reproduzem em seu ambiente. 
Face a este contexto, a presente pesquisa é desenvolvida sob a luz da Ecologia Humana em interfaces com a Antropologia e a Geografia, procurando dessa forma, analisar o comportamento da população local na interação com o ambiente, considerando além das relações sociais, os aspectos relacionados ao manejo e conservação, dentro de uma perspectiva êmica.

De acordo com Begossi (2004), a abordagem êmica das ciências sociais é baseada na percepção dos sujeitos e nos fatos históricos; dessa forma, contribui para uma contextualização sociocultural do comportamento medido, evitando assim conclusões simplistas acerca da relação do ser humano com o ambiente.

No presente trabalho a abordagem êmica será somada à abordagem ética, pois segundo Pezzutti (2004), essas abordagens não são excludentes, mas sim complementares. Nesse sentido, a abordagem ética também será utilizada, uma vez que permite ligar as informações etnográficas colhidas em campo com a teoria estudada e dessa forma realizar a análise proposta pela pesquisa.

Os conceitos de adaptabilidade e territorialidade, advindos do aporte teórico da Ecologia Humana, bem como a análise das relações sociais e o modo de vida da população local, num viés antropológico, foram os suportes teóricos dessa pesquisa, os quais auxiliaram na discussão e no entendimento de diferentes fatores ecológicos e socioculturais.

Para o desenvolvimento desta pesquisa, optou-se pela abordagem qualitativa e como método interpretativo, a complexidade, utilizando-se para coleta de dados, técnicas da antropologia, como observação participativa e entrevistas.

É importante salientar que com os resultados da pesquisa, pretende-se contribuir para a questão de forma a:

- Disponibilizar os dados e sua interpretação para a Prefeitura Municipal de Conceição da Barra, para o Parque Estadual de Itaúnas e para a Sociedade Amigos do Parque de Itaúnas - (SAPI). 


\subsection{Objetivos}

\subsubsection{Objetivo Geral}

Esta pesquisa se propõe a analisar as estratégias adaptativas da população de Itaúnas, a partir da década de 70 , tomando como base os modos de produção e modelos de subsistência e territorialidade, bem como às relações de parentesco e residência associado.

\subsubsection{Objetivos Específicos}

$\checkmark \quad$ Analisar os territórios sobrepostos numa escala temporal e espacial, baseando-se na premissa de registros históricos e do conhecimento da população local;

$\checkmark \quad$ Identificar os conflitos decorrentes da sobreposição no uso de território e os fatores estressores associados, no que se refere às estratégias de subsistência;

$\checkmark \quad$ Analisar as possíveis interferências - causadas pelo processo de implantação da monocultura de eucalipto em grande escala, da Unidade de Conservação e da atividade do turismo no modo de vida da população local e na complexa relação desses com o ambiente natural, em aspectos relacionados ao manejo e conservação de recursos naturais;

$\checkmark \quad$ Estimular o encontro entre universidade e comunidade na gestão do meio ambiente. 


\section{REVISÃO DE LITERATURA}

\subsection{Populações tradicionais e pescadores artesanais: a importância dos saberes empíricos}

O Brasil é um país que apresenta grande variedade de populações humanas que desenvolvem modos de vida e culturas próprios e diferenciados. Dependendo da tecnologia de subsistência que utilizam para garantir as necessidades materiais da vida, podem ser considerados como populações tradicionais.

Referindo-se ao tipo social e cultural do universo das culturas tradicionais do homem do campo no Brasil, Cândido (1998), em seu clássico trabalho, utiliza o termo rústico, que englobaria a cultura camponesa, cabloca ou caipira, definidas pelas características do isolamento, da posse de terras, do trabalho doméstico e da disponibilidade de terra. Sendo que estas resultaram do ajustamento do colonizador português ao Novo Mundo, seja por transferência e modificação dos traços da cultura original, seja em virtude do contato com o aborígene.

Outro importante autor que discute o conceito de populações tradicionais é Antonio Carlos Diegues. Ao longo de sua carreira, este pesquisador vem desenvolvendo trabalhos e pesquisas teóricas e práticas referentes às populações tradicionais existentes principalmente nas áreas úmidas costeiras do Brasil.

Para Diegues (2002 e 1996b), as populações tradicionais, na maioria dos casos, encontram-se isoladas, vivendo em ecossistemas ainda considerados marginais, em geral de difícil acesso e próximos a áreas rurais ou litorâneas como mangues, restingas, 
florestas tropicais etc. Essas populações resultam de intensa miscigenação entre o branco colonizador português, a população indígena nativa e o escravo negro. Elas incluem os caiçaras que habitam o litoral de São Paulo, Rio de Janeiro e Paraná; os caipiras dos estados do Sul; os habitantes de rios e várzeas do Norte e Nordeste; as comunidades pantaneiras e ribeirinhas do Pantanal Mato-grossense e os pescadores artesanais de quaisquer outras regiões.

Nas comunidades tradicionais, os sistemas de manejo não são somente formas de exploração econômica dos recursos naturais, mas revelam a existência de um complexo conhecimento empírico, adquirido pela tradição oral, herdada dos mais velhos, de mitos e símbolos que levam à manutenção e ao uso sustentado dos ecossistemas naturais (Diegues, 1994).

Empregando o conceito de populações tradicionais Diegues (1996b), define-as de acordo com as seguintes características:

"dependência e até simbiose com a natureza, os ciclos naturais e os recursos naturais renováveis a partir do qual se constrói um 'modo de vida'; conhecimento aprofundado da natureza e de seus ciclos que se reflete na elaboração de estratégias de uso e de manejo dos recursos naturais (esse conhecimento é transferido de geração em geração por via oral); noção de território ou espaço onde o grupo se reproduz econômica e socialmente; (...) importância das atividades de subsistência, ainda que a produção de mercadorias possa estar mais ou menos desenvolvida, o que implica numa relação com o mercado; reduzida acumulação de capital; importância dada à unidade familiar, doméstica ou comunal e às relações de parentesco ou de compadrio (...); importância de mitos e rituais associados à caça, à pesca e a atividades exurativistas; a tecnologia utilizada é relativamente simples (...)" (Diegues, 1996a, p. 87).

O modo de produção que caracteriza as sociedades de populações tradicionais, segundo Diegues (1996b), é o da pequena produção mercantil; isto é, ainda que produzam mercadoria para venda, são sociedades que garantem parte da subsistência por meio de atividades como agricultura de subsistência, pesca artesanal e do extrativismo. 
É importante ressaltar que as culturas tradicionais na concepção de Diegues (2000), não são estáticas, estão em constante mudanças seja por fatores endógenos ou exógenos, sem que por isso deixem de ser inseridas dentro de um modo de produção que denominamos de pequena produção mercantil.

Dentro das populações tradicionais têm-se a categoria dos pescadores. Estes estão espalhados pelo litoral, pelos rios e lagos e têm um modo de vida baseado principalmente na pesca, ainda que exerçam outras atividades econômicas complementares, como o extrativismo vegetal, o artesanato e a agricultura (Diegues, 2002).

Por pescadores, a Organização Internacional do Trabalho (OIT), considera os trabalhadores que se dedicam à captura de pescado e exercem as funções de membros das tripulações de barcos pesqueiros, executando diversas tarefas de pesca de altura, em mar aberto, - no caso dos pescadores marítimos - ou de tarefas específicas da pesca de água doce e águas costeiras. Ainda fazem parte dessa definição os coletores de esponjas e pérolas, algas e sargaços, moluscos e crustáceos, os ostricultores, baleeiros e caçadores de focas (Maldonado, 1986).

Já a pesca é definida como as técnicas desenvolvidas e empregadas na captura de animais marinhos e aquáticos, desde os crustáceos até as focas e baleias, ocupando importante ramo da atividade (Maldonado, 1986). Esta se caracteriza como uma das mais antigas atividades exercidas pelo homem, e embora ela tenha se expandido e diversificado com o passar do tempo, sob certos aspectos foram mantidas as formas básicas utilizadas pelos homens primitivos. Esse fato se deve aos métodos de pesca que embora sejam variados e muitos deles empreguem recursos modernos, todos são oriundos de sistemas que seguem as mesmas normas.

Quanto ao tipo de produção, de acordo com Maldonado (1986), os pescadores podem ser classificados em: pescadores-agricultores, pescadores industriais e pescadores artesanais. Cabe aqui destacar os pecadores artesanais, que caracterizam-se pela simplicidade da tecnologia e pelo baixo custo da produção. Este tipo de pescador tem na pesca a sua principal fonte de renda e a produção volta-se para o mercado, sem perder, contudo o seu caráter alternativo, podendo destinar-se tanto ao consumo doméstico como à comercialização. 
Cardoso (2001), afirma que a questão conceitual acerca da chamada pesca artesanal é ampla. Tal atividade envolve uma diversidade de modalidades técnicas, modos de apropriação dos recursos pesqueiros, formas de organização da produção e distribuição dos rendimentos. Sua definição não está associada apenas à questão do instrumental tecnológico empregado nas capturas, mas também às formas de organização social das pescarias.

Conforme discutido em Diegues (2002), os pescadores, sobretudo os artesanais, praticam a pequena pesca, cuja produção em parte é consumida pela família e em parte é comercializada. A unidade de produção é geralmente familiar, incluindo também conhecidos e parentes longínquos.

Para Costa (1999), as condições de realização da pesca artesanal implicam num certo modo de ordenação do tempo através do conhecimento profundo dos processos e fenômenos da natureza. Além disso, na pesca artesanal, os atores envolvidos utilizam-se do conhecimento do ecossistema marinho e das habilidades no uso dos instrumentos de produção por parte de cada pescador.

Os saberes empíricos que as populações tradicionais, incluindo os pescadores artesanais possuem, são evidentes, principalmente no manejo dos recursos naturais. No entanto, estes saberes tradicionais continuam sendo ignorados e desperdiçados pelo atual paradigma científico e econômico dominante, os quais estabelecem e incentivam ações que geram um processo de desestruturação e alteração de um grande número de modos de vida tradicionais.

As imposições do sistema econômico vigente, sobre o modo de vida tradicional, referem-se principalmente à expulsão dessas populações humanas de seus territórios ancestrais, que muitas vezes são de uso comunal, ou impedindo que continuem desenvolvendo suas atividades tradicionais para obtenção de recursos para subsistência. As práticas de exclusão e marginalização dessas populações são consubstanciadas pela expansão da grande propriedade privada e da propriedade estatal, o que tem gerado inúmeros conflitos de caráter ambiental e sócioeconômico.

Segundo a CMMAD - Comissão Mundial sobre Meio Ambiente e Desenvolvimento (1991), as forças do desenvolvimento econômico vigente conturbam os 
estilos tradicionais de vida dos povos tradicionais e indígenas. Esse desenvolvimento insensível é responsável pela extinção de seus modos de vida tradicionais. A discriminação social, as barreias culturais e a exclusão desses povos dos processos políticos nacionais deixam-nos vulneráveis e sujeitos à exploração. Muitos grupos perdem suas terras e ficam marginalizados, e suas práticas tradicionais desaparecem, tornando-se vítimas do que poderia ser chamado de extinção cultural.

Santos (2003), referindo-se aos saberes tradicionais, definido por Diegues \& Arruda (2001), como um conjunto de saberes e saber-fazer a respeito do mundo natural e sobrenatural, transmitido oralmente de geração em geração, afirma ser necessário que tais conhecimentos, produzidos por grupos sociais de indígenas e camponeses, devam ser cada vez mais reconhecidos e credibilizados. Esses conhecimentos, quando são empregados nos dias atuais, como por exemplo, a respeito das plantas e ervas medicinais, são considerados de alto valor e buscados para o desenvolvimento da biotecnologia. Nas palavras de Santos (2003), é então preciso fazer "justiça cognitiva", ou seja, reconhecer a importância desses povos e protegê-los, assim como aos seus conhecimentos.

Segundo Leff (2001), para não se perder tais conhecimentos empíricos sobre o mundo natural, deve-se promover o diálogo entre o saber tradicional e a ciência moderna para que se possa orientar os processos de re-apropriação da natureza e as práticas do ecodesenvolvimento.

Nessa direção, uma parte da comunidade acadêmica, atualmente, está valorizando e resgatando os saberes e conhecimentos empíricos de grupos humanos, que eram considerados "senso comum". Essa valorização está sendo efetuada através das Etnociências, as quais procuram estudar o conhecimento e percepções de comunidades tradicionais sobre o meio ambiente. Além disso, vem se conduzindo estudos no campo da sociolinguística que tratam das classificações, percepções e ações sobre o ambiente, praticadas por diversas culturas humanas (Guimarães, 2003; Begossi, 1993 e Morán, 1994).

O estudo em etnociências, traz informações também a respeito da diversidade biológica e o uso e manutenção de recursos naturais. Além disso, a etnociência constitui- 
se numa forma resgatar e não perder a sabedoria e conhecimento de populações tradicionais.

Nesse sentido, as etnociências vêm contribuir com a ciência moderna, propondo novos paradigmas e alternativas de vida humana, uma vez que têm como objetivo resgatar o conhecimento tradicional, através do estudo do papel da natureza no sistema de crenças e na adaptação do homem a determinados ambientes.

\subsection{Território: uma análise têmporo-espacial sobre os diferentes usos e interesses}

O tema relacionado aos sistemas comunais de apropriação de territórios e recursos é encontrado na literatura sob diferentes formas de classificação, dependendo da formação dos autores considerados e do enfoque da pesquisa. No trabalho de Freire (2001), por exemplo a classificação encontrada é a de propriedade comum. Já nos trabalhos de Ferreira (2002), Diegues (2001) e Campos (2000), encontra-se o termo terras de uso comum.

No presente trabalho para a discussão sobre sistemas de apropriação de territórios e recursos, decidiu-se adotar a classificação de terras de uso comum, devido ao caráter da pesquisa e à conotação ǵeográficá do termo.

No Brasil, grandes extensões do território podem ser consideradas imensas áreas úmidas. Entre as principais áreas úmidas litorâneas estão os sistemas costeiros, que se encontram na interface da terra com o mar. Essas, apresentam ecossistemas de manguezais, restingas e lagunas, estuários e florestas litorâneas, como partes da Mata Atlântica e são responsáveis por parte dos recursos alimentares, áreas de criação e refúgio permanente ou temporário para inúmeras espécies. Elas também funcionam como habitat para populações humanas que vivem em grande medida ou mesmo exclusivamente dos recursos naturais aí existentes (Diegues, 2001).

Nessas áreas úmidas costeiras, ainda subsistem alguns sistemas tradicionais de acesso a terras e recursos de uso comum, embora muitos tenham sido desestruturados frente à expansão capitalista. Geralmente se encontram em regiões com ecossistemas considerados marginais e em comunidades tradicionais não-urbanas. 
"As terras de uso comum, são terras de constituição natural relativamente pobres para a produção agrícola. Grande parte delas ocorrem em regiões planas, de formação geológica recente, em que dominam as restingas, mangues, dunas, vegetação de praias ou florestas de planícies quaternárias, com presença de brejos pantanosos, juncos, tiriricais" (Campos, 2000, p.71).

Juridicamente, as terras de uso comum no Brasil são enquadradas dentro de uma categoria mais ampla, a das terras públicas; isto até meados do século XIX. A partir de 1850, com a Lei de Terras, as terras de uso comum passaram a ser praticamente ignoradas, sendo inseridas dentro da categoria das chamadas terras devolutas, as quais são passíveis de apropriação individual (Campos, 2000).

Campos (2000), afirma que a categoria mais evidente de terra de uso comum é a ligada aos interesses da comunidade, ocorrendo em diferentes espaços brasileiros. Segundo esse autor:

"existem as propriedades individuais e, margeando estas, a presença de terras abertas, livres, sem dono. Por isso a comunidade acha-se no direito de utilizá-la coletivamente, sem restrições e preocupação com qualquer regime jurídico de propriedade. Esse direito é predominantemente baseado na tradição cujos usuários consideram que tais áreas eram coletivamente utilizadas desde tempos muito antigos (...)" (Campos, 2000, p.81).

As terras de uso comum apresentam características associadas a uma terra do povo - uma terra que é de todos. No entanto, não se constitui numa terra pertencente ao povo, no sentido de haver propriedade coletiva de um grupo, uma comunidade ou várias comunidades em conjunto. Trata-se do uso comum de determinados espaços por inúmeros proprietários individuais independentes, servindo-lhes como um suplemento, sendo do mesmo modo, utilizados por indivíduos ou grupos não proprietários (Campos, 2000).

Segundo Diegues (2001), nessas terras de uso comum, as populações tradicionais utilizam determinados recursos, como os peixes, plantas medicinais da mata, produtos de 
extrativismo vegetal e áreas para cultivo agrícola itinerante, sendo essenciais para a subsistência.

Nos sistemas tradicionais de acesso à terra e aos recursos de uso comum, os recursos são manejados por uma comunidade identificável de usuários interdependentes que excluem a ação de indivíduos externos, ao mesmo tempo em que regulam o uso por membros da comunidade local. Embora geralmente a ação de indivíduos externos seja excluída, esses podem ter acesso aos recursos desde que de alguma forma se identifiquem com o grupo de usuários. Estes arranjos no uso comunal são associados por uma extensa teia de relações de parentesco, de compadrio, de ajuda mútua, de normas e valores internos que privilegiam a solidariedade do grupo (Diegues, 2001).

As formas comunitárias de acesso a espaços e recursos tem, na maioria das vezes, assegurado o modo de vida das populações tradicionais. Estas por dependerem de recursos naturais para sobrevivência, acabam beneficiando um uso mais adequado dos recursos naturais. Porém, tornou-se comum a expulsão dessas populações tradicionais de seus territórios. Diegues (2001), afirma que o que tem ocorrido com maior freqüência é a "tragédia dos comunitários". Uma vez que as populações tradicionais são expulsas de seus territórios tradicionais pela expansão da grande propriedade privada, da propriedade pública e dos grandes projetos.

Os sistemas de produção baseado na posse coletiva do solo, ou outras atividades coletivamente realizadas, são bastante antigos, tanto em relação a diversas áreas do planeta, como em relação ao Brasil. E tiveram um papel significativo para diversas comunidades tradicionais brasileiras, incluindo-se nessas a população humana de Itaúnas, sujeitos colaboradores dessa pesquisa.

Freire (2001) e Campos (2000), afirmam que as terras de uso comum foram ou ainda são essenciais para a subsistência de inúmeras comunidades rurais, possibilitando principalmente, locais para a comunidade desenvolver atividades de extrativismo vegetal (cipós, fibras, ervas medicinais das florestas), extrativismo animal (caça e pesca) e a pequena agricultura. No entanto, têm-se observado a sobreposição no uso dessas terras por meio da ação de propriedades estatais e privadas. 
Essa temática relacionada às terras e recursos de uso comum, nos últimos 20 anos, está sendo bastante pesquisada e discutida, principalmente com a finalidade de revisar o estudo de Garret Hardin (1968), intitulado "A tragédia dos comuns".

Neste estudo, Hardin enfoca a relação da população humana com os recursos naturais e na propriedade de uso comum. A idéia principal é de que tais recursos de posse coletiva, como oceanos, rios, atmosfera e áreas de parque, são sujeitos à maciça degradação. O mesmo autor af̣irma que num regime de propriedade comum, necessariamente, cada comunitário tentaria aumentar seus rendimentos, aumentando a pressão sobre os recursos ocorrendo a sobrepastagem ou a sobrepesca.

Hardin (1968), argumentou que se o acesso aos bens comuns for aberto aos vários usuários, a tendência é a exploração excessiva e como consequência, a degradação de recursos é inevitável. Isso ocorreria a não ser que a propriedade comum fosse convertida em privada ou que normas governamentais sobre usos e usuários sejam instituídas.

Em outros trabalhos publicados posteriormente, Hardin, afirmou existir somente duas soluções: privatização e(ou) controle governamental. Esse autor argumentou ainda, que na medida em que não agirmos de acordo com um desses dois caminhos, “consentiremos na destruição dos recursos comuns" (Feeny et. al., 2001). Hardin estaria convencido, portanto, de que as propriedades privadas e aquelas administradas pelo Estado, podem e com muita freqüência conseguem lograr êxito no manejo dos recursos.

No entanto, a teoria proposta por Hardin tem sido revista criticamente na literatura que analisa as formas de propriedade e acesso aos recursos naturais, porque ela pressupõe uma racionalidade individual dos atores sociais envolvidos no manejo de recursos comuns. Esta racionalidade individual orientaria, segundo Hardin, uma inevitável sobreexploração desses recursos comuns.

Contradizendo o estudo de Hardin, a literatura recente tem registrado e analisado, no mundo inteiro, um número considerável de formas comunitárias de acesso a espaços e recursos que têm assegurado um uso adequado dos recursos naturais, conservando os ecossistemas e gerando modos de vida socialmente mais eqüitativos (Diegues, 2001).

Ostrom (2002), enfatiza que existem muitas comunidades locais que possuem um alto grau de autonomia para administrar seus recursos. A teoria defendida pelo referido 
autor é que não existe uma variação no desempenho dos grupos auto-organizados. Teoricamente, nem existem grupos auto-organizados. Contudo, evidências empíricas mostram que o desempenho das comunidades varia de maneira considerável, e um número cada vez maior de usuários locais têm se auto-organizado e obtido mais sucesso do que a teoria convencional propõe.

Mesmo diante das comprovações empíricas realizadas por diversos trabalhos, de que algumas populações através de suas práticas tradicionais e modos de vida ajudam na manutenção da biodiversidade, a dinâmica do sistema capitalista age de forma a fazer com que diferentes agentes favoreçam as transformações em territórios, os quais suscitam novos interesses, o que leva ao enfraquecimento da posse comunitária e à expropriação das terras de uso comum.

Cabe destacar que a expropriação não se desenvolve apenas em termos sócioeconômicos, com a perda da terra ou de bens comuns. Ela também ocorre no sentido ideológico, seja através da apropriação das idéias, ou mesmo na imposição culturalideológica sobre um determinado grupo ou um povo (Campos, 2000).

Trabalhos de Diegues (1997, 1996b, 1994 e 1993) apontam que muitas das populações tradicionais sofreram e ainda sofrem interferências no modo de vida, causadas pelas imposições do Governo no estabelecimento da propriedade estatal em seus territórios tradicionais. Essa forma de apropriação é efetuada através da implantação das Unidades de Conservação.

A implantação de Unidades de Conservação no Brasil é um dos principais elementos de estratégia para a conservação da natureza e deriva da concepção de áreas protegidas, construída no século XIX, nos Estados Unidos. Cujo objetivo é proteger a vida selvagem (wilderness) ameaçada pelo avanço da civilização urbano-industrial. Esse modelo americano de conservação expandiu-se em seguida para o Canadá e países europeus, consolidando-se como um padrão mundial, principalmente a partir da década de 60 (Arruda, 1997).

O objetivo geral dessas áreas protegidas é preservar espaços com atributos ecológicos importantes, como ecossistemas naturais, em geral de grande beleza cênica. Segundo Arruda (1997) e Diegues (1996), algumas dessas áreas, como por exemplo os 
parques - unidades de proteção integral, são estabelecidos para que sua riqueza natural e estética seja apreciada pelos visitantes, beneficiando o turismo ecológico, as gerações futuras, o equilíbrio ecossistêmico, a pesquisa científica, não permitindo a moradia de populações humanas em seu interior.

Ressalta-se que na presente discussão, não se questiona a importância das áreas naturais protegidas, mesmo porque são formas de preservar os ecossistemas, mas sim, propõe-se discutir a maneira como as Unidades de Conservação são geridas em relação à participação e à inserção da população local nas discussões de implantação e manejo dos recursos, bem como, com relação a questão da permanência de populações humanas em seu interior.

Essa última questão, relacionada a presença de populações humanas no interior de áreas protegidas, tem sido amplamente debatida e polemizada por organismos governamentais, não governamentais e de pesquisa científica nacional e internacional e constitui-se como problema central na gestão de Unidades de Conservação. Arruda (1997), afirma que uma das dificuldades permanentes na gestão e manutenção das Unidades de Conservação que adquire importância e visibilidade crescente tem sido a relação com as populações humanas que ali vivem ou viviam antes da apropriação da área pelo Estado.

$\mathrm{Na}$ discussão que envolve essa temática, existem duas linhas opostas de pensamento. De um lado os que defendem uma conciliação entre as necessidades humanas e as da natureza, propondo o uso sustentado, ao invés da preservação estrita. Dentro dessa perspectiva de conservação, as populações locais são respeitadas pelo seus saberes e podem através da proposta do co-manejo, participar das discussões, decisões e implementação das estratégias de manejo a serem adotadas pela Unidade de Conservação. Propostas desse tipo tem sido implantadas recentemente no Brasil, como no caso da Reserva de Desenvolvimento Sustentável de Mamirauá, Amazonas (Begossi et. al., 2004).

Do outro lado, há os mais radicais, que defendem a preservação no sentido mais rigoroso. Argumentando ser a ação antrópica a principal forma de degradação e não conservação da biodiversidade. Seguidores dessa linha, ainda argumentam que áreas 
estritamente protegidas serão num futuro próximo, os últimos bastiões da natureza. Por esse motivo, a proteção rigorosa dos parques deve se tornar a maior prioridade dos esforços para a conservação da natureza (Rocha, 1997).

Nessa dicotomia, percebe-se a existência de visões diferenciadas da relação ser humano - natureza, cada qual apoiada em paradigmas distintos de conservação.

Ferreira (2003), afirma que no Brasil, existem duas grandes linhas que debatem o assunto e se divergem. De acordo com a autora, o principal expoente da linha de pesquisa que defende a presença de moradores tradicionais dentro das áreas de preservação é Antonio Carlos Diegues.

Segundo esse autor a implantação de Unidades de Conservação seguindo o modelo de conservação norte-americano, entrou em conflito com a realidade dos países tropicais, cujas florestas já eram habitadas por populações indígenas e outros grupos tradicionais, que desenvolveram formas de apropriação comunal dos espaços e recursos naturais necessários a sua sobrevivência (Diegues, 1997).

Diegues (1996a), ainda argumenta que as populações tradicionais de nosso país não podem comportar em seus territórios a criação de áreas naturais protegidas semelhantes às dos países desenvolvidos, uma vez que estas possuem uma representação simbólica desses espaços, que lhes fornece os meios de subsistência, os meios de trabalho, de produção e os meios de produzir os aspectos materiais das relações sociais. A expulsão de suas terras, implica na impossibilidade de continuar existindo como um grupo portador de determinada cultura, de uma relação específica com o mundo natural domesticado.

Opondo-se à linha de pesquisa citada acima, Ferreira (2003), afirma existir os cientistas sociais que discordam da abordagem estritamente estática e limitada da cultura, e de outro lado a dos cientistas naturais como Mauro Galetti e colaboradores, que apontam que existem evidências empíricas importantes de que a caça, a alteração de habitats, especialmente pelo fogo, são os grandes responsáveis pela extinção da megafauna na pré-história da humanidade (Ferreira, 2003).

Face ao embate entre as duas concepções, concorda-se com Primack \& Rodrigues (2001), quando afirmam que atualmente existe um reconhecimento crescente de que o 
envolvimento da população local é o elemento principal que está faltando nas estratégias de manejo e conservação.

Ressalta-se, que no presente trabalho de cunho socioambiental, a discussão em torno do tema populações tradicionais em áreas de preservação, está consubstanciada de acordo com as proposições da linha de pesquisa de Diegues e seguidores. Segundo Lúcia Ferreira (2003), com a publicação de seu livro "O mito moderno da natureza intocada", Diegues, adquiriu status paradigmático para toda a pesquisa sobre manejo comunitário de recursos naturais por populações humanas.

Neste contexto, essa linha de pesquisa favorável à presença de populações humanas dentro de áreas protegidas, procura demonstrar que a melhor estratégia para a conservação da biodiversidade, é investir no envolvimento das populações tradicionais no plano de manejo e planejamento das Unidades de Conservação. Ao contrário disto a imposição autoritária de uma propriedade pública sobre comunidades tradicionais atinge sobretudo o modo de vida e sua relação com a natureza. Nesse contexto, a implantação de áreas protegidas não alcança total êxito e acaba gerando inúmeros conflitos de ordem social, econômica e ambiental.

Em países em desenvolvimento, a conservação de áreas naturais protegidas poderá ser alcançada de modo mais eficaz com a real integração e participação das populações tradicionais nas tomadas de decisão. Ao contrário, a implantação de forma autoritária, a expulsão dos moradores e não participação destes no plano de manejo tem contribuído ainda mais para a degradação dessas áreas.

De acordo com Rebello \& Foëger (2002), a política de formação de parques no Brasil, deveria ter como pressuposto a participação da sociedade, representada pela comunidade local. Ou seja, esses autores assumem que a gestão desses parques deve incluir a comunidade. Ou ainda que esta, em conjunto com os subsídios dos órgãos responsáveis e de técnicos especializados, pode desenvolver ações de manejo dessas áreas. É possível portanto, incorporar com vantagens a participação popular nessas ações de manejo, em vez de se conceber a própria estrutura do parque seguindo um modelo excludente com relação a essas populações. 
Outra forma de apropriação das terras de uso comum se dá através do estabelecimento de propriedades privadas.

$\mathrm{Na}$ propriedade privada, os direitos de exclusão de terceiros na exploração de recursos, são delegados a indivíduos (ou a grupos de indivíduos, como as empresas). Direitos de propriedade privada geralmente são reconhecidos e impostos pelo Estado. Ao contrário dos direitos em um regime de livre acesso, direitos de propriedade privada geralmente são exclusivos e transferíveis (Feeny et. al., 2001).

No Brasil, são inúmeras as grandes empresas que atuam formalmente no mercado, com ramos de atividades diversas. Estas, na maioria das vezes, extinguiram os territórios comunais, deixando as comunidades tradicionais à margem da sociedade. A extinção e ameaça sobre os territórios e modo de vida comunais, ocorre por exemplo, na expansão da grande propriedade rural voltada para a agropecuária, das grande empresas mineradoras e da agroindústria.

Referindo-se à esta última, Diegues (2002), em seu inventário brasileiro sobre as áreas úmidas costeiras, afirma que hoje a produção de celulose na Zona Costeira, vinculada à área de reflorestamento, está concentrada no norte do Espírito Santo e sul da Bahia, onde operam a Aracruz e a Bahia Sul, subsidiárias da Companhia Vale do Rio Doce (CVRD). Investimentos em reflorestamento também estão sendo realizados no Amapá pela Indústria e Comércio de Minérios S/A (ICOMI), que pretende substituir suas atividades de exploração do manganês na Serra do Navio por produção de celulose, o que já vem fazendo na Jari Florestal.

Como exemplo prático de expropriação de terras comunais por empresas privadas, Ferreira (2002), evidenciou que no início da década de 70, a agroindústria de celulose, com suas monoculturas de eucalipto, implantou-se no extremo Norte do estado do Espírito Santo. Nessa região, a instalação de empresas de celulose levou à transformação no modo de uso da terra, incentivada e legitimada pelo Estado, através de legislações específicas. Desta forma, foi imposta uma nova lógica de apropriação do espaço, ditada pela propriedade privada, pelo uso restrito, pela acumulação de capital e pelo lucro.

Segundo Ferreira (2002), 
"essa nova escala e forma de utilização do recurso natural terra, trazida pela agroindústria produziu o fim das terras de uso comum - matas, cursos d'água, lagoas e brejos que supriam grande parte das necessidades de alimentação, medicamentos, lenha e outras. A nova interferência no meio natural consuma a destruição das matas, o assoreamento, a contaminação dos rios, a perda de solos, da proteína animal da caça e do peixe, dos frutos e da madeira, produzindo a imediata alteração no modo de vida das comunidades locais que habitam essa região" (Ferreira, 2002, p.01).

O novo território da agroindústria implanta-se sobre o território das comunidades tradicionais através de um modelo de exploração econômica de elevados impactos socioambientais.

Ainda com relação à agroindústria de papel e celulose, cabe acrescentar que as empresas que atuam no Norte do estado do Espírito Santo, beneficiando-se dos incentivos fiscais que o regime militar prontamente criou para o setor florestal, beneficiaram-se também da vulnerabilidade daquele campesinato negro que não possuía registros de sua posse, tornando-se dona de uma extensa área das terras do Sapê do Norte.

A região do Sapê do Norte, como era conhecida a região nordeste do estado do Espírito Santo, englobava os municípios de Conceição da Barra e São Mateus. Ali viviam até a década de 1970, cerca de 10.000 famílias rurais negras distribuídas em torno de 100 comunidades. O Sapê do Norte é o local onde se estabeleceram historicamente, boa parte das comunidades remanescentes de Quilombos da região. O résultado do processo de expropriação das terras pelas empresas privadas que se estabeleceram no local, foi a expulsão de milhares de famílias para a periferia das cidades vizinhas e para capital do estado (Arruti \& De'Nadai, 1998).

Algumas dessas comunidades, mesmo tendo suas terras reduzidas a minúsculas propriedades isoladas entre si pelos talhões de eucalipto, resistiram ao processo de expropriação, mas vêm sofrendo as conseqüências do processo de degradação ambiental. Uma vez que a produtividade do solo vem sendo reduzida, os lençóis freáticos estão se 
esgotando, muitos córregos e rios já secaram inteiramente e a exposição aos agrotóxicos tem levado as pessoas à morte, à cegueira e a uma série de problemas de saúde.

Outro exemplo prático é evidenciado em Diegues (2002), este afirma que no final da década de 60, com o incentivo do Governo à indústria da pesca moderna, as empresas pesqueiras então, se voltaram para a exportação de alguns produtos nobres, como por exemplo, o camarão. Nesse sentido, era de grande interesse que o mar estivesse livre das marcas características dos sistemas de apropriação tradicional. Como conseqüência dessas atividades industriais, seus grandes barcos passaram a entrar em conflito com as embarcações dos pescadores artesanais e seus sistemas de manejo, acarretando na dificuldade dessas populações de exercerem suas atividades de pesca.

Com os exemplos citados pela literatura, se torna evidente $o$ fato do estabelecimento da propriedade privada ou de grandes corporações, não necessariamente leva à proteção dessas propriedades. Tem-se constatado entre outros problemas ambientais, erosão do solo, poluição dos corpos d'água, além dos danos sociais, econômicos e culturais para as populações tradicionais.

Outro ponto relevante para essa discussão é o fato de que ocorreu e ainda ocorre nos territórios tradicionais, forte expansão do turismo e da especulação imobiliária, levando rapidamente à expropriação de muitos territórios de uso comum e à desorganização das culturas tradicionais. Nesse processo, muitas comunidades tradicionais foram retiradas de seus territórios para dar lugar a redes de hotéis, pousadas e complexos turísticos. Diegues (2001), exemplifica essa problemática citando o conflito gerado em uma comunidade tradicional em motivo da compra da Praia de Trindade, no litoral sul do Rio de Janeiro por uma empresa canadense, a Brascan, para implantação de um complexo turístico.

As populações que sofreram os impactos advindos da compra de terrenos bem próximos da praia, apesar de seu grande conhecimento dos ecossistemas que contribuíram para a preservação do local, foram ignoradas no processo desapropriação e os grandes proprietários apossaram-se de seus territórios ancestrais.

Campos (2000), relata que as terras litorâneas têm sido desde a Colônia, o espaço tradicionalmente mais valorizado. A partir da década de 70 , inicia-se por toda a fachada 
litorânea uma sobrevalorização desse espaço, em decorrência do setor turístico. Muitos pequenos proprietários, sem a total noção de valor comercial, acabaram por vender suas terras por preços irrisórios para os padrões do mercado. Muitos deles, com o tempo, tornaram-se caseiros dos novos proprietários, nas terras que antes lhes pertenciam e de onde extraíam boa parte de sua subsistência.

Através da consulta das pesquisas e estudos empíricos realizados no Brasil, e da reflexão sobre os mesmos, aqui desenvolvidas, ficaram claras as implicações e consequências da adoção da propriedade privada e estatal, em detrimento da posse comunitária.

\subsection{A introdução de novas atividades econômicas e a relação das comunidades tradicionais com o sistema capitalista}

Um elemento de extrema importância na discussão desse trabalho, é o turismo. Este, da maneira que vem se consolidando, pode ser considerado um estressor que age alterando a estrutura do local receptor, desestruturando o modo de vida das populações nativas, além de gerar impactos ambientais e sócioculturais.

Neste sentido, serão apresentados, neste tópico alguns conceitos importantes para estabelecer uma discussão sobre esse fenômeno que cresce cada vez mais no cenário brasileiro.

De acordo com Silva (2003) e Ignarra (2000), um dos aspectos mais importantes para o início do turismo foi o homem deixar de ser sedentário e começar a viajar motivado pela necessidade de estabelecer comércio com outros povos.

O hábito de realizar viagens para outras localidades é um fenômeno antigo na humanidade. Ignarra (2000), cita que na antigüidade, as pessoas viajavam por vários motivos, tais como: curiosidade, interesses econômicos, sentimento religioso, esportivo e também, por motivos de saúde.

A origem desta atividade ocorreu motivada pela descoberta da humanidade, da sua capacidade de locomoção, abrindo caminhos pelos quais encontrou novas formas de satisfação de suas necessidades. Essa forma de satisfação que o homem tem buscado de 
maneira incidental ou intencional, estabeleceu-se a partir do conhecimento de novas culturas, da busca do lazer, do descanso, das situações, dos atrativos ou eventos que viessem a lhe proporcionar emoções (Silva, 2003).

Com relação ao Brasil, Silva (2003), afirma que desde os tempos de D. João VI, registraram-se notícias sobre movimentos turísticos. Nessa época, inúmeros cientistas e comerciantes, entre eles, o francês Saint-Hilaire, estiveram em nosso país, fascinados por suas belezas naturais.

No início do século XIX, com a mudança da corte portuguesa para o Brasil, cresce a demanda por hospedagem na cidade do Rio de Janeiro. Já na metade do século XIX, existiam no Rio de Janeiro entre hotéis, hospedarias e restaurantes, cerca de 200 estabelecimentos. Em 1908, era inaugurado o Hotel Avenida na cidade do Rio de Janeiro, com 220 quartos, o maior do Brasil, marcando o início da hotelaria moderna do país (Ignarra, 2000).

Silva (2003) e Ignarra (2000), salientam também, que em 1927, a empresa aérea Lufthansa cria no Brasil a Condor Sindicat que mais tarde daria origem à VARIG. Estas empresas posteriormente dão impulso para o desenvolvimento do turismo interno $\mathrm{e}$ externo.

É importante ressaltar que apenas em 1968, o governo brasileiro criou os primeiros instrumentos de regulamentação da atividade com a criação do Conselho Nacional do Turismo (CNTUR), o Fundo Geral de Turismo (FUNGETUR) e a Empresa Brasileira de Turismo (Ignarra, 2000).

Hoje, o turismo é definido pela Organização Mundial do Trabalho (OMT), como “o deslocamento para fora do local de residência, por período superior a 24 horas e inferior a 60 dias, motivados por razões não-econômicas".

Tal definição explicitada acima, auxilia a padronizar o conceito de turismo, mas não indica a real magnitude desse fenômeno. Desde 1910, vários autores procuram conceituar o fenômeno, sendo este considerado de enorme dimensão e complexidade (Ignarra, 2000).

Santana (1996), comenta que não existe uma definição de turismo universalmente aceita. As várias ciências que possuem interesse em estudá-lo, vêm se propondo defini-lo 
de acordo com suas especificidades. Dessa forma, faz-se necessário analisar os diversos aspectos do turismo, com a finalidade de reuni-los em uma definição abrangente e interdisciplinar.

Muitos autores como por exemplo Santana (1996), afirmam que o turismo caracteriza-se como uma forma especial de utilização do tempo livre e de recreação, sendo um dos seus aspectos fundamentais, o lazer. Sendo então o turismo considerado como uma manifestação do lazer, se constitui como uma atividade especial ou excepcional, uma vez que nem sempre o tempo livre é utilizado para realizar o turismo.

Para complementar, Santana (1996), afirma que o turismo representa uma forma especial de aproveitamento do tempo livre e de recreação. Acrescenta ainda, que uma definição de turismo que seja suficientemente abrangente não pode centrar sua atenção unicamente nos aspecto funcional ou em seu agente ativo: o turista. Afinal, o turismo é um fenômeno social que envolve o surgimento e desenvolvimento de instituições, relações interpessoais e situações peculiares.

O turismo, na literatura, aparece também como uma atividade econômica, no momento de seu surgimento, ou seja, a partir da organização da viagem, com pacotes turísticos, excursões, guias, hotéis etc, concretizando-se como uma prática de grande complexidade. Além disso, a principal função do turismo é proporcionar ao turista a recuperação da fadiga, do estresse que o trabalho proporciona na nossa sociedade moderna, bem como a oportunidade de conhecer e apreciar ambientes e culturas diferentes.

Como atividade econômica, o turismo apresenta uma série de elementos dispersos que tentam ser articulados na formação de uma verdadeira "indústria". Um dos elementos principais que vem a ser a matéria-prima dessa indústria é constituído pelos assim denominados "atrativos turísticos" (Silva, 2003).

O atrativo turístico é o elemento que chama a atenção das pessoas sobre aquele lugar e é capaz de atrair os visitantes para determinado local. Podem ser aspectos naturais como as paisagens e o clima ameno, ou culturais, como os prédios históricos, os museus, as festas tradicionais, além dos próprios hábitos, usos e costumes relacionados à origem étnica da população humana local (Silva, 2003). 
Quaisquer que sejam as motivações dos viajantes, estes consomem serviços de turismo. Esses consumidores, de acordo com a OMT, podem ser classificados como turistas, excursionistas e visitantes.

Segundo Ignarra (2000), a Organização das Nações Unidas (ONU), em 1954, adotou o conceito de turista como: "toda pessoa, sem distinção de raça, sexo, língua e religião, que ingresse no território de uma localidade diversa daquela em que têm residência habitual e nele permaneça pelo prazo mínimo de 24 horas e máximo de seis meses, no transcorrer de um período de 12 meses, com a finalidade de turismo, recreio, esporte, saúde, motivos familiares, estudos, peregrinações religiosas ou negócios, mas sem propósito de imigração".

Já o indivíduo que não pernoita em uma localidade turística é considerado excursionista ou turista de um dia. E como visitantes, costuma-se designar os participantes de cruzeiros marítimos ou fluviais que visitam uma localidade, mas que pernoitam nas embarcações (Ignarra, 2000).

Ressalta-se que na literatura que abarca estudos sobre a atividade do turismo, são evidenciados muitos aspectos negativos relacionados a esse fenômeno. Um desses aspectos é destacado em Santana (1996), e refere-se aos impactos do turismo de massa. Esse tipo de atividade caracteriza-se pelo grande número de pessoas que o realizam, acarretando grandes concentrações de turistas nos locais de destino. Além disso, esse tipo de turismo promove a exploração destrutiva do meio ambiente e a diluição dos costumes e das tradições das comunidades receptoras.

No ambiente físico, o impacto do turismo se consolida por meio de muitos fatores. Alguns deles são: construção de infra-estrutura turística, visitação massiva a microambientes frágeis, excesso de resíduos sólidos gerados pelos turistas, exceder a capacidade de carga, isto é, o número máximo de visitantes por período de tempo que uma determinada área pode suportar, sem que ocorram alterações nos meios natural e cultural etc.

Quanto aos impactos do turismo na cultura e no modo de vida das populações receptoras, Ignarra (2000), chama atenção para o processo de aculturação. Ressalta a existência de um comportamento psicossocial, onde as comunidades mais tradicionais, ao 
terem contatos com povos de países mais desenvolvidos tentam imitá-los, o que leva à alteração de valores culturais tradicionais.

Outro aspecto citado por Ignarra (2000), refere-se à arquitetura tradicional e ao artesanato, que são transformados a partir da demanda turística.

Observa-se em muitos casos, que o desenvolvimento da atividade turística não tem sido acompanhado de um planejamento adequado, não propiciando condições para uma maior participação da população local, nem o entrosamento entre os vários segmentos sociais envolvidos. Esse fato cria inúmeros conflitos e entraves a uma proposta de desenvolvimento ambientalmente compatível, economicamente viável e socialmente justa, tendo como suporte a dinâmica local e o planejamento participativo.

Percebe-se que os povos nativos têm sido muitas vezes descartados do processo de implantação do turismo, propiciando o aumento dos índices de pobreza e marginalidade. $\mathrm{O}$ desenvolvimento do turismo sem planejamento, freqüentemente tem provocado a degradação do meio ambiente e a desestruturação da economia e do modo de vida das populações locais.

Nesse sentido, é necessário o redirecionamento desta atividade, desenvolvendo estratégias válidas para buscar a integração entre uso turístico, preservação do meio ambiente e melhoria das condições de vida das comunidades locais.

De acordo com Silva (2003), a atividade turística pode gerar benefícios para as comunidades nos locais onde se desenvolve, se estiver inserida dentro de um planejamento adequado, considerando-se as características da região em que se localiza o pólo turístico, bem como o desenvolvimento sócioeconômico e a cultura de seu povo, sendo esses fatores imprescindíveis para o sucesso dessa atividade.

Outro aspecto a ser considerado para se evitar um crescimento caótico e desordenado das instalações da estrutura turística, é a criação e o desenvolvimento de um plano diretor fundamentado na concepção do planejamento como um processo dinâmico no qual planos, tomadas de decisões, implementação e revisão, sejam organizados com a participação efetiva de todos os interessados.

No caso em que o turismo é implantado sem um planejamento adequado, e é desenvolvido em locais onde existem populações tradicionais, este desempenha um papel 
de transformador do modo de produção local. Ou seja, a população passa a atuar como mão-de-obra barata e a se relacionar com outro tipo de produção, a capitalista, abandonando seus modos de produção tradicionais e perdendo o conhecimento relativo aos mesmos.

De fato, conforme citam Ignarra (2000) e Rodrigues (1997), as comunidades tradicionais, com o advento do turismo, vão abandonando suas próprias atividades para se dedicar a atividades tais como as de caseiros, empregadas domésticas, de barqueiros para passeios turísticos, pedreiros etc.

Para Diegues \& Nogara (1994), o modo de produção que caracteriza as formas sociais de produção das comunidades tradicionais é o da pequena produção mercantil. São sistemas em que o trabalho assalariado é ocasional e o que prevalece é o trabalho autônomo e familiar. Porém, percebe-se que as populações tradicionais já não se encontram mais dentro dessa lógica, mas sim dentro da lógica do mercado. Devido a rápidos processos dinâmicos em seus territórios, algumas populações passaram a estabelecer de alguma forma, relações com o modo de produção capitalista.

De acordo com Diegues (1996a), as culturas tidas como tradicionais, decorrentes da pequena produção mercantil, no Brasil de hoje, não se encontram mais isoladas, mas articuladas ao modo de produção capitalista. Diegues (1996b), também salienta que as culturas tradicionais estão articuladas de forma diferenciada com a sociedade dominante e encontram-se transformadas em maior ou menor grau. Além disso, afirma que um dos processos desorganizativos reside na uniformização cultural produzida pelo capitalismo e pela sociedade de massas.

Carvalho (2001), estudando o caso da população local de São Sebastião-SP, afïrma que o processo de perda de seus territórios, constituiu-se no início da desorganização das relações sociais, econômicas e culturais dessa população. Com a perda das terras, os moradores locais perderam também suas fontes de sobrevivência, trabalho e consequentemente, sua cultura, fortemente arraigada ao ambiente litorâneo.

O processo de perda de território, verificado em muitos locais do Brasil, somado à impossibilidade de acesso aos recursos naturais, significou para as populações tradicionais, a ausência de espaço para a manutenção de seu modo de vida. 
Face a esse contexto, aumentaram as necessidades das populações tradicionais possuírem produtos que já não produzem mais. Assim, essas populações passaram a desenvolver com maior intensidade, outras atividades ligadas ao modo de produção capitalista. Essas atividades consolidaram transformações nas suas relações sociais, nas relações de trabalho e nos valores da população.

Cândido (1998), assinala que um dos fatores principais da mudança na vida dos caipiras do interior de São Paulo, está no fato de estes perderem suas terras, passarem a viver do trabalho agrícola assalariado, criando uma dependência maior para com o mercado urbano e perdendo as algumas afinidades positivas para com o meio natural.

$\mathrm{Na}$ literatura referente ao tema, encontram-se vários elementos que contribuíram para o processo de desestruturação do modo de vida tradicional e o acentuaram. Entre eles destacam-se: a perda e venda do território, a adoção de novos padrões de usos dos recursos naturais e a entrada do turismo.

Esses fatos mencionados acima, acabaram por afastar em alguns casos, as populações tradicionais da floresta e dos recursos naturais. Nesse contexto, as populações passaram então a ter outras necessidades, criando dependência cada vez maior do mercado e se afastando das atividades de subsistência.

Carvalho (2001), referindo-se a essa problemática, relata que o caiçara de São Sebastião, pescador, artesão, canoeiro ou lavrador, se encontra marginalizado social e economicamente e destituído de seus direitos ancestrais de uso dos recursos naturais. Neste contexto, busca formas de inserir-se economicamente no mercado e garantir sua sobrevivência.

Um outro exemplo disto, é relatado no trabalho de Ferreira (2002), onde as comunidades rurais do extremo norte do Espírito Santo, através da implantação da monocultura de eucalipto no norte desse estado, perderam suas terras da roça e da floresta. Essa perda representou um golpe fatal na subsistência destas comunidades, construídas através do uso extensivo do meio natural.

Ainda referindo-se às comunidade do Espírito Santo, mais precisamente aos habitantes de Itaúnas, Rebello \& Foëger (2002), afirmam que com a implantação do Parque Estadual, somada às atividades da monocultura de eucalipto, os moradores aos 
poucos foram perdendo literalmente seu território. Nesse processo, a população passouse a lançar-se em novas atividades econômicas, associadas ao turismo.

Carvalho (2001), comenta que o turismo pode transformar os modos de produção e de subsistência da população receptora, por meio da consolidação da passagem de uma economia onde a maior parte das necessidades são atendidas pela produção da própria comunidade, para uma economia onde o salário prevalece.

A partir da consulta aos trabalhos de Ferreira (2002), Rebello \& Foëger (2002), Carvalho (2001), Diegues (1996b e 1994), pode-se concluir que a maior parte das populações residentes nas regiões costeiras brasileiras, expropriadas de seus territórios e não tendo acesso ao recursos naturais, passaram a se inserir em outras atividades $\mathrm{e}$ também em atividades ligadas ao turismo. Essa transição pode ser analisada como estratégia adaptativa para garantir sua sobrevivência dentro da lógica do capitalismo.

\subsection{Fatores estressores relacionados a população humana}

As transformações no espaço físico (território), as interferências no modo de vida causados pela atividade turística e o processo de modernização, podem ser considerados como estressores que atuaram ou estão atuando na área de estudo desta pesquisa. Nesse, sentido busca-se aqui entender e ampliar a discussão em torno do assunto.

No glossário de ecologia Academia de Letras do estado de São Paulo (1987), estresse é conceituado como o conjunto de reações de um sistema a um agente que perturba sua homeostase. Estressor para Morán (1994), pode ser considerado como o fator de limitação claramente definido, ou seja, um problema que induz respostas na população ou indivíduo.

Para Kormondy \& Brown (2002), todos os organismos, inclusive os humanos devem enfrentar os problemas apresentados pelo meio ambiente, tanto para sobreviver como para se reproduzir. Esses ajustes estão associados ao processo de adaptação dos organismos frente aos estressores. 
Ainda referindo-se ao conceito de estresse, na concepção de Morán (1994), este é considerado como uma força ou situação extrema em um ambiente onde está um organismo ou uma população, que produz um desvio da homeostase.

$\mathrm{O}$ conceito de homeostase é entendido aqui como uma tendência apresentada pelos sistemas biológicos de resistirem às mudanças ambientais e permanecerem em um estado de equilíbrio.

Na concepção de Kormondy \& Brown (2002), o estresse é tanto uma variável ambiental à qual os organismos precisam se adaptar, quanto uma reação corpórea ao ambiente (a reação de alarme), como também, uma variável que medeia o estímulo e a resposta dependendo das percepções a um dado estímulo.

Ecólogos estudando a capacidade dos organismos de se adaptarem ao ambiente, impressionaram-se ao verificarem a presença de adaptações ocultas, ou seja, a existência de organismos que são capazes de se adaptar a condições mais extremas do que aquelas a que estão de fato expostos, mostrando-se capazes de suportarem condições altamente estressoras (Kormondy \& Brown, 2002).

Kormondy \& Brown (2002), apresentam também o conceito de estresse ambiental, este visto como uma condição externa (a um organismo), que causa uma alteração potencial prejudicial em sistemas biológicos. Esses mesmos autores defendem a idéia de que existem mais de um estressor ambiental, e esses podem ser divididos entre os que derivam de fontes físicas ou de fontes biológicas. Acrescentam ainda, que alguns organismos, particularmente os humanos, devem também lidar com outras fontes de estresse, as sociais.

Os fatores estressores sociais para Kormondy \& Brown (2002), são mais difíceis de caracterizar, mas incluem questões relacionadas com casamento e reprodução, assim como competição dentro de famílias de grupos e entre grupos por recursos considerados importantes.

Os estressores com que as populações humanas vêm se confrontando são de fontes bióticas, dentre as quais incluem-se a má-nutrição e as doenças infecciosas e as abióticas, que englobam os extremos de temperatura, perigos naturais e diversos tipos de poluição 
ambiental. Um outro tipo, também considerado como fator estressor, ocorre por meio do processo de modernização das sociedades (Kormondy \& Brown, 2002).

Kormondy \& Brown (2002), afirmam ainda existir evidências de que em várias populações, os níveis de estresse aumentam durante o processo de modernização. Porém, estes declinam uma vez que os indivíduos se adaptam às suas novas circunstâncias. Em todos os casos, são estimulados pela percepção de ameaça.

Conforme completam Kormondy \& Brown (2002), muitos dos estressores com os quais temos que lidar são criações da própria humanidade. Ressaltam ainda, que a permanência da espécie humana no planeta a longo prazo, depende de nossa habilidade de lidar com esses desafios ambientais auto-induzidos.

Morán (1994), acrescenta ainda que formas constantes e extremas de estresse podem ser enfrentadas por meio de ajustes de desenvolvimento, de aclimação e pelos ajustes reguladores. Porém, este mesmo autor afirma que as formas mais comuns de ajustamento talvez sejam as comportamentais, sociais e culturais, sendo essas formas mais flexíveis, visto que dependem menos de ajustes do organismo físico em si, e mais da plasticidade comportamental que este permite.

\subsection{Estratégias adaptativas em populações humanas}

Sendo o objetivo principal deste trabalho, analisar as estratégias adaptativas dos moradores locais da área em estudo, faz-se necessário revisar os conceitos relacionados ao tema adaptação em populações humanas. Assim, neste tópico do trabalho, os conceitos de adaptação, adaptabilidade e outros termos relacionados, serão discutidos, com o objetivo de fundamentar teoricamente a discussão em torno dessa temática.

Segundo Adams (2002) e Foley (1993), os conceitos de adaptação e adaptabilidade, são amplamente utilizados principalmente em pesquisas de Ecologia Humana. Entretanto, deve-se considerar que existem na literatura diferentes definições e sentidos acerca desses, os quais ora diferem entre si, ora se complementam. Nesse sentido, adaptação é um termo de uso freqüente em ecologia, mas tem diversos significados ou nuanças, dependendo da abordagem que os autores estão empregando. 
Neste trabalho, os conceitos de adaptação e adaptabilidade serão explicitados de acordo com as referências de alguns autores selecionados, com a finalidade de obter uma concepção integrada e holística desses conceitos.

Para Adams (2002), adaptação pode ser definida como a sobrevivência de um grupo em um dado ambiente ou seu ajuste para sobreviver em um novo ambiente, tanto físico, como sócio-cultural.

Por sua vez, Migliano (2000), afirma que a adaptação refere-se tanto ao processo pelo qual os organismos aumentam a sua capacidade de explorar os recursos dentro de um dado nicho, quanto às características que lhes permitem fazê-lo e que o processo adaptativo é mediado pelo nível de competição intra e interespecífica e pela seleção natural.

No sentido não evolucionista e mais comum, Morán (1994), assume que adaptação pode se referir às mudanças fisiológicas e comportamentais provocadas por alterações ambientais. Acrescenta ainda, que este conceito tem considerável poder explicativo quando empregado de modo abrangente, com o objetivo de estudar processos pelos quais uma população interage com seu ambiente. Segundo esse autor, o termo adaptação é a essência da abordagem ecológica, sendo decorrente da exposição a fatores físicos e químicos existentes no ambiente, da interação com outras espécies e da interação com outros indivíduos da mesma espécie (Morán, 1990).

$\mathrm{Na}$ tese apresentada por Adams (2002), é possível distinguir quatro tipo diferentes de adaptação, que não existem isoladamente uns dos outros, mas são conectados' através do tempo e de mecanismos de feedback (retro-alimentação):

1- filogenética/ genética: envolvendo adaptação trans-gerações de um genótipo através da seleção natural;

2- fisiológica: modifícação no fenótipo durante o ciclo de vida do indivíduo, dentro das possibilidades genotípicas;

3- comportamental/ aprendizado: aquisição de comportamentos adaptativos ao longo do ciclo de vida;

4- cultural: modificação através da combinação de aprendizado e informação culturalmente transmitida. 
Com relação ao conceito de adaptabilidade, na literatura este é visto por autores como Adams (2002), Kormondy \& Brown (2002) e Morán (1994), como tendo um significado diferente do conceito de adaptação.

Apesar de haver uma sobreposição entre as definições de adaptação e adaptabilidade humana, esta última não se sobrepõe à adaptação no sentido genético. A adaptabilidade pode ser definida como a capacidade de se adaptar e deve ser usada para se referir ao tipo de respostas que os indivíduos apresentam frente a mudanças em seu ambiente, que facilitam sua sobrevivência e reprodução, devendo ser considerada uma propriedade potencial de determinado grupo (Adams, 2002).

Para Morán (1994), a abordagem dos estudos sobre adaptabilidade humana está centrada em como as populações humanas, ao interagirem umas com as outras e com seus ambientes, procuram se acomodar a estes problemas ambientais extremamente específicos. Os diversos níveis de ajustamento possíveis têm por fim aumentar a adaptabilidade. Assim, adaptabilidade humana inclui processos fisiológicos $\mathrm{e}$ comportamentais, bem como adoção de fatores culturais originários de outras populações.

Para Kormondy \& Brown (2002) e Morán (1994), o estudo da adaptabilidade humana enfatiza a plasticidade das respostas humanas ao ambiente. Esta plasticidade manifesta-se tanto em termos socioculturais como fisiológicos. Neste sentido, a abordagem dos estudos sobre a adaptabilidade humana trata mais de problemas específicos enfrentados pelos habitantes de diversos ambientes do que do ambiente propriamente dito. Ou seja, nessas abordagens não se considera o ambiente como "algo" estático que limita as possibilidades humanas.

Ainda, segundo Morán (1994), os indivíduos podem responder às alterações de seu ambiente por meio de ajustes, sendo estes: reguladores, de aclimação e desenvolvimento.

Os ajustes reguladores ocorrem de forma rápida e refletem a flexibilidade fisiológica e comportamental de um organismo. Quase todo comportamento é uma forma de resposta reguladora que serve para manter uma relação estável com o ambiente ou que permite um ajuste a mudanças ocorridas no mesmo. Os ajustes de aclimação levam mais tempo para entrar em operação, pois exigem uma mudança na estrutura do organismo. 
Para que ocorram, é preciso que haja um estímulo externo por um período de tempo suficiente. Estes geralmente são revertidos quando cessa a situação que produziu a alteração orgânica. Já os ajustes de desenvolvimento são irreversíveis e ocorrem durante o crescimento e desenvolvimento do indivíduo. Suas respostas são ajustamentos do organismo às condições ambientais que predominam durante o período de desenvolvimento. É durante esse período que o organismo é capaz de se moldar às condições ambientais predominantes, o que pode ser compreendido como plasticidade genética (Morán, 1994).

Além desses tipos de ajustes, Morán (1994), acrescenta a esta discussão, mais uma categoria, definida por ele como ajustes culturais e sociais. Os culturais incluem um vasto repertório de conhecimentos adquiridos pelos membros de uma sociedade sobre a natureza. Essa categoria abrange também o conhecimento sobre a construção das habitações, estilos de vestuário, tecnologia de subsistência e rituais, permitindo que a espécie humana reaja rapidamente às mudanças ambientais. Os ajustes sociais por sua vez, incluem sobretudo formas de organização social e econômica. Em conjunto, ambos se caracterizam como ajustes flexíveis, infinitamente variáveis, as alterações no habitat e nas relações com outros grupos humanos.

Weiss ${ }^{2}$, citado por Adams (2002) assegura que para muitos organismos a adaptação é um processo quase inteiramente biológico. Já na espécie humana, a cultura é um fator adicional de suma importância no estabelecimento de estratégias adaptativas.

Neste sentido, a adaptação cultural pode ser muito rápida, já que ela possibilita, às vezes, que o indivíduo ultrapasse a etapa de tentativas e erro, utilizando a experiência adquirida por outros indivíduos (Adams, 2002).

A maneira mais comum de adaptação cultural, segundo Adams (2002), é através dos mecanismos de problemas percebidos e respostas conscientes, onde os indivíduos e populações podem modificar ativamente seu comportamento para manter ou alterar

\footnotetext{
${ }^{2}$ WEISS, B. Nutritional adaptation and cultural e maladaptation: an evolutionary view. In: NORGE, R.F.K.; JEROME, W., PELTO, G.H. Nutritional antropology: contemporary approach, 1980. p.147179.
} 
certas condições, melhorar as existentes e lidar com os problemas ambientais e(ou) com estressores.

Indivíduos vivendo em sociedades pré-industriais são capazes de sobreviver graças a um extenso conhecimento do habitat quanto à localização de alimento e matéria-prima, fabricação de instrumentos e manipulação dos alimentos, proteção contra predadores, além de inúmeros fatores como o conhecimento da organização do parentesco e dos comportamentos rituais (Adams, 2002).

Porém, uma vez que a organização social e o modo de produção dessas populações humanas sejam modernizados, passando a se desenvolver dentro de uma outra lógica, a do capitalismo, a população passa a desenvolver estratégias adaptativas para a sobrevivência face às novas condições. Segundo Morán (1990), essas estratégias referem-se ao ajuste da população ao novo ambiente e às novas condições sociais, podendo envolver modificações fisiológicas ou comportamentais. Constituem-se em planos de ação, conscientes e inconscientes, explícitos ou implícitos, empregados por uma população em respostas às condições externas ou internas.

Discutindo as estratégias de sobrevivência numa dimensão de cunho sócioeconômico, estas correspondem à maneira como as unidades domésticas vêm se adaptando ao meio econômico, cultural e geográfico, que tem constituído seu entorno e sua rede de relações sociais (Cristiani \& Félix, 1999).

Ribeiro (1989), também considera as estratégias de sobrevivência como arranjos, "truques" adaptativos que se realizam no agregado familiar, nos grupos e nas comunidades, visando maximizar a renda e o consumo, assegurando dessa forma a manutenção da família. Esses "truques" adaptativos podem se fundamentar na combinação de diversas atividades, através da formação de uma rede de relações sociais que geralmente não se limita à família.

É importante recordar que, quanto mais adaptada uma espécie estiver ao seu ambiente, maiores serão as chances dos indivíduos desta população sobreviverem, reproduzirem-se e, consequentemente, ocuparem seu território (Morán, 1994).

Em suma, nos estudos de ecologia humana, os conceitos ora apresentados, estão inter-relacionados, podendo ser úteis na compreensão da relação ser humano e ambiente 
como um todo. Ou seja, fornecem subsídios para entender a capacidade do ser humano de responder aos problemas que podem ser de caráter ambiental, sócio-econômico ou cultural.

\subsubsection{Sistemas de parentesco e núcleos residenciais}

Visto que o sistema de parentesco é um aspecto importante para a compreensão das relações sociais, este se faz presente nesta discussão com o objetivo de melhor compreender como as sociedades humanas organizam sua estrutura social. Além disso, os sistemas de parentesco podem estar associados tanto à posse como à defesa do território, e ainda à organização dos núcleos residências.

Segundo Service (1966), em cada sociedade existe um sistema de parentesco, ou seja, um conjunto de princípios e regras que governam o comportamento dos parentes uns com os outros, as reciprocidades nas quais eles se engajam, os direitos e deveres que eles têm uns para com os outros, os termos pelos quais eles se dirigem uns aos outros e os tipos de agrupamentos dentro dos quais eles estão organizados. Ressalta-se que os elementos de um sistema de parentesco, constituem-se em um importante aspecto dos ajustamentos culturais do grupo.

Para Lévi-Strauss (1973), uma estrutura de parentesco, por mais simples que seja, nunca poderá ser construída a partir da família biológica composta pelo pai, pela mãe e pelos filhos, mas ela implica, desde o início, uma relação de aliança. Esta aliança está relacionada à família que cedeu a mulher para se casar.

Uma estrutura de parentesco então, consiste em um marido, uma mulher, um filho e um representante do grupo do qual o primeiro recebeu a segunda. Esta estrutura de parentesco que Lévi-Strauss (1973), chama de átomo de parentesco, ou seja, o sistema quadrangular de relações entre irmã e irmão, marido e mulher, pai e filho, tio materno e sobrinho, é designada por este autor como sendo a estrutura mais simples para se entender e às vezes até observar.

Nas comunidades de pescadores, camponeses, grupos indígenas, entre outros grupos tradicionais, as relações de parentesco se efetuam de diferentes maneiras. Cada 
grupo estabelece seu sistema de parentesco de acordo com as lógicas internas do grupo. É uma forma de se organizarem e de estabelecerem direitos e deveres.

Nas sociedades tradicionais, como é o caso da sociedade caiçara de São Sebastião, Carvalho (2001), relata que a unidade familiar sempre foi importante e representa uma unidade de produção e consumo de bens, onde pais e filhos são responsáveis pela produção de alimento, construção da casa e elaboração dos utensílios, pela pesca e pela vida social e cultural da comunidade em que estão inseridos.

Entre os índios Pirahã, do município de Humaitá - Amazonas, Gonsalves (1997), observou que através das noções de consangüinidade e afinidade, criam-se duas formas de classificação distintas: os parentes distantes e os parentes próximos. A partir destas classificações, tais índios engendram-se formas distintas de reciprocidade $\mathrm{e}$ consequentemente, diferenças que reproduzem níveis de inclusão e exclusão dos núcleos residenciais ou dos conjuntos maiores.

Os arranjos matrimoniais são também responsáveis pela maneira como o grupo se organiza no espaço. Gonsalves (1997), relata que os casamentos entre os indivíduos podem ocorrer no interior de um mesmo núcleo residencial, entre núcleos, ou até mesmo se dar entre os conjuntos mais distantes.

Dentro dos sistemas de parentesco existem também outros laços entre os indivíduos da sociedade que não são sangüíneos, são os de sistemas de compadrio. Para Morán (1990), esses mecanismos de compadrio são efetuados para ampliar o grupo cooperativo ao qual os indivíduos têm acesso. Evidencia-se nesse sistema, a visitação, a ajuda mútua, a partilha de recursos padronizados, o casamento entre membros de diferentes grupos e o comércio estabelecido entre os grupos.

Neste contexto, a solidariedade é vista por Ferreira (2002), como um princípio organizativo, sendo um dos traços característicos da comunidade tradicional. O mutirão testemunha práticas de cooperação e pode ser solicitado por quem está precisando ou mesmo ser oferecido pelos vizinhos. Neste tipo de trabalho, mutirão, não existe remuneração, mas relação de solidariedade e compromisso moral em corresponder aos pedidos de auxílio por parte daqueles que ajudaram. 
Cândido (1998), reportando-se às formas de solidariedade, faz referência ao bairro e não somente à família, no sentido restrito. Um bairro, dentro deste contexto, é definido por esse autor, como o agrupamento territorial, mais ou menos denso, cujos limites são traçados pela participação dos moradores em trabalhos de ajuda mútua. Um dos elementos que o caracterizam, é o trabalho coletivo.

Na sociedade caipira, a manifestação característica mais importante é também o mutirão, sendo considerado por Cândido (1998), uma prática tradicional, que soluciona o problema de mão-de-obra nos grupos de vizinhança, suprimindo as limitações da atividade individual ou familiar. Geralmente os vizinhos são convocados e o beneficiário lhes oferece alimento e uma festa que encerra o trabalho.

Um outro elemento importante na presente discussão, refere-se aos padrões de povoamento e de residências. Para Morán (1994), os padrões de povoamento da população humana refletem ajustes à distribuição de recursos e aos fatores sociais e culturais.

Gonsalves (1997), observou que na sociedade dos Pirahã, as localidades são herdadas em linha agnática (entre os que descendem de um mesmo tronco masculino; linhagem patrilinear), assegurando aos parentes lineares o controle sobre um território. A ênfase na linearidade é responsável por relacionar indivíduos a espaços, ao mesmo tempo, que define seus direitos no uso e na ocupação. A herança do território passa de pai para filhos.

Os locais são identificados com os seus controladores. $\mathrm{O}$ filho mais velho tem $\mathrm{o}$ controle sobre todos os locais que pertenceram a seu pai. Posteriormente, divide o controle com seu grupo masculino. Controlar um lugar significa, antes de tudo, estar vinculado a uma área e ter um território reconhecido para habitação, perambulação e exploração de seus recursos; os locais são pontos em que as pessoas se fixam e organizam seu raio de movimentação. Há, em um nível, uma identidade reconhecida por se compartilhar um mesmo espaço territorial e os mesmos parentes paternos, fato que, por sua vez, engendra uma diferença entre pessoas que não conseguem se ligar pela proximidade geográfica e por relações genealógicas (Gonsalves, 1997). 
Quanto aos núcleos residenciais, temos o exemplo dos Pirahã. Gonsalves (1997), afirma que a conformação dos seus conjuntos e sua manutenção no tempo devem-se a três fatores: a "herança do território", a classificação dos parentes em "próximos" e "distantes" e os casamentos, preferencialmente contraídos no interior dos conjuntos. Os núcleos que fazem parte de um conjunto mantêm relações pautadas pela contigüidade espacial e pelos laços de consangüinidade e afinidade.

Nos núcleos residenciais dos Pirahã, Gonsalves (1997), relata que se torna difícil precisar o grupo doméstico ou a família elementar como unidade de produção e consumo. $\mathrm{O}$ casal é a unidade mais perceptível; por meio desta unidade a fragmentação da vida social ganha amarração e sistematicidade. A autonomia do casal é evidenciada nas expedições de pesca e de coleta. Por um lado, o casal produz a fragmentação, estimula o estilo de vida autônomo, não gregário, marcado por uma forma provisória de viver (mudanças constantes, abrigos frágeis, bens escassos). Por outro lado, o casal aparece como unidade fundamental, opera como um ordenador das relações sociais, costurando, mesmo que de forma tortuosa, o tecido social do grupo.

Diante dos exemplos citados, pode-se afirmar que em cada soçiedade existe um sistema de parentesco regido por regras e lógicas internas que favoreçam o grupo. Através desses exemplos, pode-se também perceber a forma com que os grupos se organizam no território, na obtenção de recursos com relação aos deveres e obrigações de cada indivíduo.

\subsubsection{Do conceito de território à noção de territorialidade}

De acordo com Haesbaert (2002), território e territorialidade são conceitos bastantes difundidos, principalmente na ciência geográfica. Este autor, ressalta ser de fundamental importância compreendê-los, uma vez que contribuem para um debate mais amplo, no que refere às novas e cada vez mais complexas problemáticas envolvidas nas formas com que a sociedade modela e organiza o espaço no qual se reproduz.

Assim, buscando o sentido etimológico da palavra território, Corrêa (2002) e Mesquita (1995), declaram que esta deriva do latim "terra" (terra) e "pertencente a" 
(torium), significando terra pertencente a alguém. Porém, Corrêa (2002), salienta que a expressão pertencente, não se vincula à propriedade da terra, mas à sua apropriação e esta por sua vez tem um duplo significado. De um lado está associada ao controle de fato efetivo, por vezes legitimado, por instituições ou grupos sobre um determinado segmento do espaço. Por outro lado, apropriação pode assumir uma dimensão afetiva, derivada das práticas espacializadas por parte de grupo distintos. Os dois significados podem, contudo, interagir-se, definindo territórios plenamente apropriados, de direito, de fato e afetivamente.

Referindo-se à história da concepção de território, Haesbaert (2002), afirma existir duas vertentes interpretativas que se opuseram, mas em sua concepção, jamais podem ser vistas separadamente.

A primeira concepção de território é a de caráter naturalista, a qual vê o território num sentido físico, material, como algo inerente ao próprio ser humano, quase como se ele fosse uma continuidade do seu ser. Como se o ser humano tivesse uma raiz na terra. Essa tal concepção seria justificada sobretudo, pela necessidade de território e de seus recursos para a sobrevivência biológica. A outra concepção, envolve o campo dos sentidos e da sensibilidade humana, que seriam moldados pela natureza e pela paisagem ao seu redor. Esta visão sobrevaloriza e praticamente naturaliza uma ligação afetiva, emocional, do ser humano com seu espaço.

Raffestin (1993), afirma que o território se forma a partir do espaço. É o resultado de uma ação conduzida por um ator sintagmático (ator que realiza um programa) em qualquer nível. Ao se apropriar de um espaço, concreta ou abstratamente, o ator territorializa o espaço. O sentido do agir e da apropriação são expressos pelo autor claramente, quando afirma que o território é um espaço onde se projetou um trabalho, seja energia e informação, e que, por conseqüência, revela relações de poder.

Neste presente trabalho, concorda-se com Milton Santos (2002), quando este afirma que o território não é apenas o conjunto dos sistemas naturais e sistemas de coisas superpostas, mas tem que ser entendido como o território usado, não o território em si. $\mathrm{O}$ território usado é o chão somado à identidade. A identidade é o sentimento de pertencer 
àquilo que nos pertence. Então, o território é o fundamento do trabalho, o lugar da residência, das trocas materiais e espirituais, do exercício da vida.

Somando-se à idéia citada acima, Oliveira (1991), assegura que o trabalho legitima a posse da terra, é nele que reside o direito de propriedade. Segundo esse autor, quando o trabalhador se apossa da terra, esta se transforma em terra de trabalho. Diferentemente da terra de negócio, que se refere a terra apropriada pelo capital em detrimento da expropriação e exploração do trabalho alheio.

O território é também para Haesbaert (2002), visto antes de tudo, como o espaço concreto em que se produzem ou se fixam os processos sociais. Mas, visto dentro de uma dimensão simbólica, o território pode ser considerado fruto de uma apropriação simbólica, especialmente através das identidades territoriais, ou seja, da identificação que determinados grupos sociais desenvolvem para com seus espaços vividos.

Faria (2001), esclarece que a concepção de território está ligada à idéia de domínio ou gestão de uma determinada área. Esta área recebe uma função, dependendo da forma de apropriação. A apropriação pode ser tanto de grupos sociais, do poder público estatal e(ou) do poder das grandes empresas capitalistas que lançam seus tentáculos por grandes áreas territoriais. Neste contexto, assume-se um duplo sentido, seja pelo controle de fato efetivo, legitimado pelo poder, ou por outro lado, vinculando-se à dimensão afetiva e associando-se à identidade de grupos sociais e à afetividade espacial (uma relação até certo ponto cosmológica).

Haesbaert (2002), em sua obra, remete-nos à uma outra discussão que se refere à noção da desterritorialização culturalista, ou seja, os "não-territórios" culturalmente falando. Assim, os territórios por sofrerem modificações, perdem o sentido/o valor de espaços aglutinadores de identidades, na medida em que as pessoas não mais se identificam simbólica e afetivamente com estes, ou se identificam com vários deles ao mesmo tempo, podendo mudar de referência espacial-identitária com relativa facilidade.

A idéia de ligação afetiva e também a defesa por parte do ser humano, do território que habita, nos faz ampliar esta discussão e acrescentar um outro elemento, ou seja, o conceito de territorialidade. No entanto, destaca-se aqui que no presente trabalho o conceito de territorialidade será empregado procurando respeitar a sua 
multidimensionalidade, ou seja, suas várias dimensões. Assim, este conceito será compreendido tanto do ponto de vista biológico, como também do ponto de vista das ciências humanas.

Neste sentido, concorda-se com Raffestin (1993), quando este assume que a territorialidade adquire um valor bem particular, uma vez que assume a multidimensionalidade do vivido territorial, pelas sociedades em geral. $\mathrm{O}$ autor ainda afirma que os homens vivem ao mesmo tempo um processo territorial e uma produção territorial por intermédio de um sistema de relações existenciais e(ou) produtivistas.

Concorda-se também com Andrade (2002), quando este afirma que a territorialidade é encarada como:

"um processo subjetivo de conscientização da população de fazer parte de um território, ou seja, a ligação ou a inter-relação entre ambos, sendo o conjunto das práticas e suas expressões materiais, capazes de garantir a apropriação e permanência de um dado território por um determinado agente social, tendo muitas características com o espaço vivido, marcado por trocas de experiências entre o território e o indivíduo por serem ambos dinâmicos, interagindo reciprocamente" (Andrade, 2002, p. 214).

Segundo Faria (2001), a territorialidade está também relacionada com as raízes que o indivíduo cria com o lugar vivido, ao longo de sua vida e(ou) permanência nesse lugar, o que faz valorizar sua cultura. A valorização da vida simples, do cotidiano (ato de caminhar pela manhã em ruas arborizadas, pescar nos rios, dormir embaixo de árvores em redes, conversar à noite sob o luar etc.), todos esses pequenos atos, podem provocar um sentimento de confraternização das pessoas com o lugar.

Chávez (2002), discutindo a territorialidade dentro de uma dimensão cultural, afirma que esta pode ser definida como a construção do espaço, a dotação de sentido ao lugar que se habita, ao qual se pertence através de práticas cotidianas. Essas práticas referem-se aos modos pelos quais um determinado grupo social consegue reproduzir sua 
cultura. Além disso, a territorialidade é o sentimento que emana da consciência de pertencer a um território.

Uma outra visão importante do conceito de territorialidade está apoiada na vertente das ciências biológicas. Neste contexto, assume-se que o conceito de territorialidade está relacionado com a conduta característica adotada por um organismo para tomar posse de um território e defendê-lo contra os membros de sua própria espécie (Raffestin, 1993).

Assumindo-se que a territorialidade também está ligada à idéia de riqueza e distribuição espacial dos recursos mais vitais dentro da área de domínio e ao processo pelo qual um ou mais indivíduos delimitam uma certa área e a defendem de invasão por outros indivíduos da mesma espécie, a territorialidade poderá estar ligada à defesa do território e às estratégias de uso e exploração dos espaços coletivos e individuais, dos quais vão ser extraídos os recursos naturais para subsistência e os materiais necessários para o desenvolvimento da tecnologia característica desta sociedade.

Segundo Wilson (1981), cada cultura desenvolve suas próprias regras particulares para salvaguardar a propriedade e o espaço individual. Este mesmo autor afirma que na espécie humana há um maior controle conservacionista sobre o ambiente, quando há uma demarcação territorial definida sobre uma região.

Entendendo a territorialidade numa relação dialética entre as duas dimensões, material e simbólica, e remetendo este conceito ao estudo sobre populações humanas que habitam áreas naturais, temos abaixo exemplos práticos, extraídos de estudos realizados por alguns pesquisadores e comentados a seguir.

Luchiari (2001), referindo-se às formas de instalação de infra-estrutura do turismo no Brasil, salienta existirem contradições entre o lugar e as territorialidades impostas por esta atividade. Assim afirma que:

"não é justo, nem ético que nossas populações locais sejam varridas de suas territorialidades para dar lugar a formas-conteúdo exógenas, que vão tomando de assalto extensas áreas transformando a natureza em um bem de acesso seletivo, e excluindo as populações autóctones da nova organização sócio-espacial" (Luchiari, 2001, p. 21). 
Essa autora ainda afirma que a atividade turística com sua infra-estrutura, impõe novas territorialidades. Salienta que sua implantação, rouba do lugar, parcelas do seu território, para construir ali um conteúdo social estrangeiro (Luchiari, 2001).

Chávez (2002), comenta que em estudos sobre seringueiros da Reserva Extrativista Chico Mendes, percebe-se territorialidades distintas, frutos, por um lado, da permanência e de compenetração para com o território e da diversidade de recursos naturais da floresta, da exigência produtivista e da sujeição do trabalhador ao patrão seringalista patente no modelo monoextrativista da borracha e por outro lado territorialidade da reserva, que emerge do caldo moderno da revaloração do tradicional, do comunitário ecológico.

Em Itaúnas, conforme discutido em Ferreira (2002), existem territorialidades distintas que se concretizam por meio do uso comunal tradicional e do uso empresarial, comercial e também governamental.

Através dos exemplos práticos, pode-se perceber que com a introdução de novas formas de apropriação do território, tanto estatal, como particular e por empresas privadas, as populações humanas envolvidas nestes processos passam a criar novas e distintas territorialidades, ou seja, novas formas de concepção de uso e do processo de domínio e apropriação do território, que estão ligados aos seus interesses.

Em síntese, afirma-se que as populações humanas podem manter relações estreitas com o território, sendo isto expresso, por meio da territorialidade, ou seja, através do sentimento de pertencer ao território vivido, da sua defesa etc.

Cabe mencionar que de acordo com Andrade (2002), é necessário encarar o território e também a territorialidade como categorias temporárias, uma vez que no espaço e no tempo nada é permanente, mas se acha em constante transformação.

Em última instância, cabe citar que "a vida é tecida por relações, dai a territorialidade pode ser definida como um conjunto de relações que se originam num sistema tridimensional, sociedade, espaço e tempo" (Raffestin, 1993, p.160). 


\section{METODOLOGIA}

"O pensamento complexo, tenta dar conta do
que significa originalmente o termo
complexus, 'o que tece em conjunto' e
responde ao apelo do verbo latino
complexere: 'abraçar'. O pensamento
complexo é um pensamento que pratica o
abraço" (Edgar Morin, 2002).

Face as discussões e questionamentos sobre a ciência e o fazer ciência, Thomas Kuhn, na década de 70 com sua obra clássica "A estrutura das revoluções científicas" trouxe contribuições importantes à história do fazer científico, por meio da discussão do conceito de paradigma e da questão das revoluções científicas.

Segundo Kuhn (1975), nos diversos momentos históricos e nos diferentes ramos da ciência há um conjunto de crenças, visões de mundo e formas de trabalhar reconhecidos pela comunidade científica, configurando o que ele chama de paradigma. Sendo este o responsável por determinar para uma comunidade científica quais as questões importantes e a melhor maneira de respondê-las.

Kuhn (1975), acrescenta ainda a idéia de que um paradigma aceito em uma determinada época, é muito aprofundado, até que este entra em crise, pois surgem problemas que ele não consegue resolver, então uma nova teoria é apresentada, predominando a antiga. A essa questão ele chama de revoluções científicas. Afirmando que o progresso da ciência se faz pela quebra de paradigmas, ou seja, pela colocação em discussão das teorias e dos métodos.

A partir dos estudos de Thomas Kuhn, pensadores contemporâneos como Fritjof Capra, Edgar Morin, Leonardo Boff e Boaventura de Sousa Santos, tem se posto à tarefa de discutir essa temática, ou seja, o período de revolução científica, os sinais da crise 
paradigmática e as especulações sobre o paradigma emergente. Uma vez que hoje, são muitos os indícios de que o modelo de racionalidade científica, pautado no paradigma cartesiano, atravessa uma profunda crise. Nessa direção, temos visto com muita freqüência enunciados que denotam a insuficiência das explicações científicas, explicações estas, inadequadas ao mundo contemporâneo e aos problemas ambientais, sociais, econômicos e culturais, como a fome, a miséria e a degradação ambiental (Santos, 2003 e Almeida, 2002).

Boff (1999), delineando sobre paradigma, afirma este ser um conjunto de princípios, valores e idéias compartilhados por um determinado grupo, que serve como referência e também de orientação. Esse conjunto de idéias forma uma determinada visão da realidade e projeta o método científico correspondente.

Já Morin (2002), afirma que "o paradigma instaura relações primordiais que constituem axiomas, determinam conceitos, comandam discursos e(ou) teorias. Organiza a organização deles e gera a geração ou regeneração".

Nos dias atuais, o paradigma científico que mais influencia os pensamentos, as idéias e os valores em nossa civilização, foi sendo construído progressivamente desde o século XVII. Os cientistas mais influentes na estruturação deste pensamento, foram Francis Bacon, Isaac Newton e René Descartes. Esse paradigma, passou primeiro a orientar a observação científica, a formulação de todas as teorias dos fenômenos naturais e mais tarde abarcou também os estudos das sociedades humanas (Santos, 2003 e Capra, 1982).

Dentro desse paradigma dominante, o Universo é visto como um sistema mecânico, sendo analisado a partir da fragmentação de seus elementos. A natureza é também vista por metáforas de maneira análoga às máquinas. Partindo dessas idéias, o antigo conceito da natureza como mãe nutriente que imperava na Idade Média, foi drasticamente transformado, dando lugar à concepção de natureza fragmentada. Assim, dentro dessa visão mecanicista e sob o patriarcado, a natureza passa a ser controlada e dominada pelo ser humano, sendo tida como valor de uso e exploração (Capra, 1982).

Ainda em relação ao domínio do ser humano sobre a natureza, Almeida (2002), em um esforço anticartesiano, reflete sobre os frágeis fundamentos de que o ser humano 
seria um ser ímpar, superior em tudo e a todos os outros seres vivos. Para a autora, esses tipos de fundamentos legitimaram durante muito tempo a relação perversa e suicida da dominação da natureza pelo ser humano.

Concordo com Capra (1982), quando este afirma que devido à excessiva ênfase apenas no método científico e no pensamento linear disseminados pelo paradigma cartesiano, podemos hoje observar atitudes antiecológicas, onde o ambiente natural é visto como se fosse formado de peças separadas e exploradas por diferentes grupos de interesse. A compreensão sistêmica da vida ainda é dificultada pela própria mente racional, que segue um pensamento linear e fragmentado.

Este tipo de pensamento que está dentro da concepção mecanicista, compartimenta, isola e percebe a realidade viva e social através do olhar objetivo, ignorando o subjetivo, sendo incapaz de conceber a complexidade dos problemas da humanidade. É um pensamento reducionista, que estilhaça a complexidade, pois analisa o mundo em fragmentos desunidos e fraciona os problemas. Este pensamento é um tipo de inteligência míope, que às vezes chega a ser cega (Morin, 2001).

Nesse sentido, Morin (2001), ressalta que o mundo está precisando realizar uma reforma do pensamento epistemológico. Uma vez que vivemos hoje no quinto século da era planetária, de um mundo interligado, no qual os fenômenos, biológicos, psicológicos, sociais e ambientais são todos interdependentes. Os desenvolvimentos da era planetária nos confrontam cada vez mais e de maneira cada vez mais inelutável com os desafios e problemas da humanidade (Morin, 2002).

Face aos enunciados da crise paradigmática, há emergência de novas buscas para se fazer ciência. Uma ciência que permita trabalhar as idéias de forma menos fracionada e mais interligada e com uma racionalidade mais plural. Nessa direção, Morin (2002), nos instiga a pensar os problemas atuais de acordo com a complexidade. $\mathrm{O}$ mesmo autor ainda afirma que há complexidade quando elementos diferentes do todo são inseparáveis, como o econômico, o político, o sociológico, o psicológico, o afetivo e o mitológico, e há um tecido interdependente interativo e inter-retroativo entre o objeto de conhecimento e seu contexto, as partes e o todo, o todo e as partes, as partes entre si. 
Entretanto, Morin (1996), adverte-nos para não conceber a complexidade como receita ou resposta e sim considerá-la como desafio e como motivação para pensar.

Em suma, pode-se dizer que a complexidade tende para o conhecimento multidimensional, ou seja, ela não quer dar todas as informações sobre um fenômeno estudado, mas respeitar suas diversas dimensões. Dessa forma, é preciso sempre lembrar que o ser humano é um ser biológico e sociocultural e que os fenômenos sociais são ao mesmo tempo econômicos, culturais, psicológicos etc (Morin, 1996).

Diante do exposto, cabe ressaltar que a presente pesquisa se conduziu sob o prisma desse paradigma que emerge, na intenção de buscar conhecimentos multidimensionais e respostas para os problemas socioambientais da atualidade, frutos de processes dinâmicos da relação ser humano e ambiente.

\subsection{Abordagem da pesquisa: qualitativa}

Devido ao universo subjetivo e complexo desta pesquisa, optei pela abordagem qualitativa com a finalidade de examinar aspectos mais profundos e subjetivos do tema em estudo. Além disso, a abordagem qualitativa propiciou criar um relacionamento mais longo e flexível entre o pesquisador e os indivíduos envolvidos na pesquisa, lidando com informações intrínsecas, amplas e com maior riqueza de detalhes.

A abordagem qualitativa é apropriada numa pesquisa quando um fenômeno é complexo, de natureza social e não tende à quantificação. Normalmente essa abordagem é utilizada quando o entendimento do contexto histórico, social e cultural é um elemento importante para a pesquisa (Dias, 2000a).

Segundo Minayo (1994), a pesquisa qualitativa se preocupa com um nível de realidade que não pode ser quantificado, ou seja, ela trabalha com o universo de significados, motivos, aspirações, crenças, valores e atitudes, o que corresponde a um espaço mais profundo das relações, dos processos e dos fenômenos que não podem ser reduzidos a operacionalização de variáveis.

A abordagem qualitativa empregada nesta pesquisa, buscou dados qualitativos e uma análise do problema investigado, interpretativa. Dessa maneira, procurou 
compreender o fenômeno estudado a partir dos dados coletados em campo, das referências fornecidas pela população estudada em seu mundo vivido e dos significados atribuídos ao fenômeno pela população.

$\mathrm{Na}$ presente pesquisa, buscou-se dados históricos e atuais a respeito das experiências dos sujeitos da pesquisa, em situações concretas, dentro de seu mundo vivido. Este, entendido aqui, como aquele mundo de ambigüidades, comprometimentos e significações no qual estamos inextricavelmente envolvidos em nossas vidas diárias e está inter-relacionado a três fenômenos da experiência, que constituem seus pólos, o espaço como experienciado, paisagem como a superfície limitante do espaço e lugar como centros de significado no espaço e paisagem (Relph, 1979).

Como a pesquisa se propõe analisar o comportamento dos moradores frente aos problemas socioambientais da Vila de Itaúnas-ES, optei pelo estudo de caso, um dos tipos de pesquisa qualitativa.

De acordo com Dias (2000b), o estudo de casỏ por utilizar várias técnicas de coleta de dados, permite que os fenômenos sejam observados em seu ambiente natural, onde uma ou mais entidades (pessoa, grupo, organização) são examinadas, sendo que os resultados dependem fortemente da integração do pesquisador a esse ambiente.

Para Santos (2002), no estudo de caso, não há manipulação ou controle dos sujeitos pelo pesquisador. Além disso, o estudo de caso se constitui numa metodologia que permite estudar tanto os fenômenos que estão em curso como os que já aconteceram.

Assim, além dos aspectos históricos, o estudo de caso foi útil na captura de aspectos mais recentes, emergentes na vida da população humana estudada, do fluxo de atividades da mesma, especialmente em fases de grandes e rápidas mudanças.

\subsection{Procedimentos}

Essa pesquisa desenvolveu-se entre dois caminhos, o teórico e o empírico, possibilitando desdobramentos que contribuíram para o entendimento do tema abordado, bem como para o desenvolvimento da própria investigação. 
Para o desenvolvimento da pesquisa não se utilizou apenas uma técnica isolada, mas um conjunto dessas, todas pertinentes e(ou) apropriados, conforme as proposições de Marconi \& Lakatos (1999), os quais afirmam que para determinados casos, pode-se utilizar um conjunto de técnicas, ou seja, as que forem necessárias e apropriadas, para um melhor aprofundamento do problema investigado. Sendo que na maioria das vezes há combinação de duas ou mais delas usadas concomitantemente.

Para observar e interpretar os fenômenos e comportamentos da população humana estudada, utilizei a perspectiva êmica. Desse modo, trabalhei com os moradores de Itaúnas, numa relação on'de eles foram vistos como colaboradores na coleta dos dados necessários para a pesquisa, sendo a experiência vivida por eles em seu ambiente, uma das principais fontes desta pesquisa.

Em suma, dentre os procedimentos para a coleta de dados de uma pesquisa qualitativa, utilizei um conjunto de técnicas instrumentais, as quais auxiliaram a busca de dados e informações a respeito do tema estudado na presente pesquisa e abaixo estarão comentadas.

\subsection{Técnicás de pesquisa instrumentais para a coleta de dados}

\subsubsection{Trabalho de campo e observação participante}

Para coletar dados necessários, realizei trabalho de campo no cenário da pesquisa, efetuado em duas etapas. A primeira, com duração de 15 dias e a segunda com duração de 58 dias.

Os termos "trabalho de campo" e "pesquisa de campo", segundo Haguette (1992), eram usados por antropólogos e sociólogos para contrapor aos trabalhos de "antropólogos de gabinete". Tanto os sociólogos que faziam trabalho de campo concentrado nos estudos de comunidades ou pequenos grupos, como os interacionistas simbólicos que estavam preocupados em descobrir os sentidos que as coisas tem para a ação humana, utilizavam a observação participante como técnica de pesquisa para a coleta de dados. Esses 
pesquisadores julgavam que as técnicas convencionais não eram capazes de captar este "sentido", acreditando ser a observação participante a mais apropriada para fazê-lo.

A observação participante, constitui-se em uma técnica de pesquisa, utilizada desde os trabalhos de campo e estudos realizados por Malinowski. Sendo Florence Kluckhohn, a primeira a ter utilizado o termo e definido a regra de que, o observador participante deve compartilhar nas atividades de vida e sentimento das pessoas em termos de relações face a face. Dessa forma o observador participando com os observados em seu ambiente natural de vida, coleta os dados (Haguette, 1992).

Kluckhohn ${ }^{3}$ citada por Haguette (1992), descreve a observação participante como sendo um compartilhar consciente e sistemático, conforme as circunstâncias o permitam, nas atividades de vida, e eventualmente nos interesses e afetos de um grupo de pessoas.

Seguindo essas proposições, a técnica da observação participante foi utilizada na presente pesquisa, sendo direcionada de acordo com os objetivos propostos pela pesquisa. Através de um roteiro, procurei registrar as observações feitas em várias situações, contemplando assim elementos significativos da dinâmica dos indivíduos envolvidos na pesquisa, no que se refere aos aspectos ecológicos, socioculturais e econômicos.

Na primeira etapa do trabalho de campo, efetuada no mês de abril do ano de 2003, três anos após o meu último contanto e visita à Vila de Itaúnas, foi possível estabelecer os contatos iniciais com os moradores de Itaúnas, localizar os informantes e coletar dados. Estar em campo nesse período, foi essencial, pois pude realizar observações sobre a dinâmica dos moradores em dois momentos distintos do seu cotidiano, ou seja, em período com movimento turístico e sem movimento turístico.

No período em campo, quando havia um fluxo considerável de turistas, pude então realizar observações no momento em que os moradores estavam em uma dinâmica voltada às atividades de.turismo. Em seguida, com minha permanência no campo, tive a oportunidade de observar outra realidade, onde as atividades desenvolvidos pelos

\footnotetext{
${ }^{3}$ KLUCKHOHN, F. The participant - observer technique in small communities. Journal of Sociology, v.46, p.331, 1940 .
} 
nativos, ligadas ao turismo, tinham diminuído drasticamente; como eles próprios afirmam era "o fim da temporada de verão".

É importante ressaltar aqui, que neste primeiro contanto como pesquisadora na Vila de Itaúnas, houve da minha parte uma adaptação ao ritmo e aos costumes do local e um processo de retomada da interação com alguns membros da comunidade local, o que foi fundamental para obter os dados necessários para a pesquisa.

$\mathrm{Na}$ outra etapa do trabalho de campo, em 2004, minha permanência se estendeu durante os meses de junho, julho e agosto, totalizando 58 dias. Ressalto, que nessa segunda etapa do trabalho de campo, meu olhar sobre a unidade empírica da pesquisa se dava de forma mais crítica e procurei dentro do possível, transformar o confronto entre os dois mundos distintos, o meu e o de Itaúnas, em um encontro de troca, estabelecendo acima de tudo uma relação dialógica com os moradores.

Além disso, o período de tempo que permaneci em Itaúnas, que considero longo, foi fundamental e permitiu estabelecer um contato maior com a população local, cultivando com os mesmos um envolvimento de respeito.

Em campo, participei das atividades diárias dos moradores, em seu ambiente natural de vida. Esta convivência com os moradores, propiciou criar uma relação de confiança com os mesmos. Dessa forma, muitos dados e informações importantes foram revelados. Sendo que isso não havia acontecido em momento anterior, quando fiquei um curto período de tempo em campo e utilizei como técnica de coleta de dados, entrevistas utilizando-se um gravador.

Nos dois meses de imersão e observação participativa em campo, pude observar as mudanças que ocorrem em Itaúnas, participar, compartilhar e vivenciar a trama do cotidiano dos moradores. Ouvir suas estórias, seus desabafos. De acordo com Ferreira (2002), no cotidiano, as conversas e desabafos passam a ser testemunho, depoimento e memória.

Destaco aqui, que em todo esse trabalho utilizei uma caderneta de campo, onde registrei diariamente os fatos e acontecimentos observados e também as entrevistas informais realizadas nos trabalhos de campo. A caderneta de campo foi de extrema 
importância para não serem perdidos os insights ao longo das observações realizadas, ou seja, as reflexões a respeito do que eu havia observado.

Em campo, tudo o que achei importante foi anotado na caderneta, ou seja, falas e fatos relevantes para a pesquisa. Nesse sentido, a caderneta de campo foi onde depositei todas as observações, reflexões e memórias.

Nas pesquisas qualitativas, torna-se indispensável a utilização de um diário de campo, em que são anotadas desde as observações feitas até as impressões subjetivas tidas pelo pesquisador com relação a fatos ocorridos na comunidade em que se desenvolve o seu trabalho (Viertler, 2002).

\subsubsection{Entrevistas}

A técnica da entrevista permite suprir a ausência de informações em documentos, com relação à área estudada e entender a dinâmica do local, sendo bastante adequada para a obtenção de informações acerca do que as pessoas sabem, crêem, esperam, sentem ou desejam, pretendem fazer, fazem ou fizeram, bem como acerca de suas explicações ou razões a respeito dessas coisas. Essa técnica também possibilita notar a expressão corporal do entrevistado, bem como a tonalidade da voz e ênfase nas respostas (Gil, 1999).

Para a realização das entrevistas, procurei ao invés da aleatoriedade, escolher informantes intencionalmente, considerando uma série de condições. Ou seja, informantes que fossem essenciais para o esclarecimento do assunto em foco, a viabilidade de encontrá-los e o tempo disponível desses indivíduos para as entrevistas. Neste processo de escolha de um bom informante, fiquei atenta às pessoas mais antigas no grupo estudado e ao envolvimento destas desde o começo no fenômeno que desejava estudar. Pois, conforme afirma Haguette (1992), o informante relata através de suas próprias observações, aquilo que viu ou sentiu ao longo de sua experiência.

Nesse sentido, para a realização das entrevistas foram selecionados em primeiro lugar, os moradores mais idosos de Itaúnas, para obtenção de dados sobre aspectos físicos, sociais, culturais e econômicos da antiga Vila de Itaúnas, bem como sobre o 
modo de vida dos mesmos, quando ainda viviam naquele local, o qual foi coberto pelas dunas, na década de 70 .

Realizei também entrevistas com outros moradores, mais jovens e também com os mais idosos. Essa segunda série de entrevistas teve como objetivo apreender elementos significativos sobre os conflitos referentes as transformações ambientais, econômicas culturais e sociais, causadas pela sobreposição no uso do território, no espaço e no tempo, bem como nos ajustes da população para se adaptar a nova realidade imposta e ao universo do manejo e conservação do ambiente natural.

Entrevistas também foram realizadas com residentes de Itaúnas, migrantes de diversas cidades do Brasil, principalmente de capitais. O mesmo procedimento foi adotado com funcionários do parque e donos de pousadas. $\mathrm{O}$ objetivo de entrevistar tais pessoas foram diversos, focando por exemplo, com os funcionários do parque, assunto relacionado as aspectos relacionados ao manejo e conservação. Já com os donos de pousadas o objetivo foi compreender porque instalaram pousadas no local, número de empregados, condições oferecidas para os funcionários, expectativas de lucro etc.

As entrevistas realizadas se dividiram em semi-estruturadas e formais, em que utilizei um gravador para registrar os depoimentos e em entrevistas informais, onde foram anotados os principais aspectos na caderneta de campo. $\mathrm{O}$ total de entrevistados foram 33. Dos quais 10 foram gravados e 23 foram divididas em entrevistas formais e informais, ambas sem gravador.

\subsection{Análise e interpretação dos dados}

As entrevistas que foram registradas com gravador, foram transcritas. Posteriormente procurou-se, juntamente com o conteúdo de todas as outras entrevistas que não foram gravadas, identificar os temas relevantes, assim como as idéias que continham contradições, visando estabelecer categorias para análise, de acordo com os objetivos propostos pela pesquisa. $\mathrm{O}$ mesmo procedimento foi adotado para a leitura e análise da caderneta de campo. 
Tal procedimento foi adotado pois, conforme afirma Gil (1999), as respostas fornecidas tendem a ser muito variadas. Assim, para que se possa analisá-las adequadamente é preciso organizá-las, o que é feito mediante o seu agrupamento em um certo número de categorias.

Assim, privilegiou-se como categorias de análise, as questões ligadas a sobreposição no uso do território, as estratégias adaptativas quanto ao modo de produção, à territorialidade, relações de parentesco e às representações mentais dos moradores quanto ao tipo de ligação com o ambiente natural que os cercam, elementos da tradição presentes no modo de vida da população humana e os aspectos ligados ao manejo e conservação do ambiente natural.

\subsection{Caracterização e discussão geográfica e histórica de Itaúnas}

\subsubsection{Aspectos geográficos}

A Vila de Itaúnas, distrito rural pertencente ao município de Conceição da Barra, se localiza na porção norte do Estado do Espírito Santo, região Sudeste do Brasil. Distante a $256 \mathrm{Km}$ de Vitória, capital do Estado, Itaúnas, está entre as coordenadas geográficas, latitude S18 25"10' e longitude W39 42"32'. Vide figura 1. O acesso até a Vila é difícultado pelos $22 \mathrm{Km}$ de estrada de terra, que em várias épocas do ano se encontra em más condições.

O nome Itaúnas é originário da expressão itá (substantivo feminino de origem tupiguarani) que significa pedra e una (adjetivo de origem tupi-guarani), o que é preto, escuro. Na praia de Itaúnas existem formações rochosas no mar, que ficam expostas quando a maré esta baixa. São arenitos de cor preta, em processo inicial de latificação, do Quaternário, chamados de beach-rocks. Supõem-se que os índios denominaram essa região de Itaúnas, em função dessas formações.

Quanto ao clima, este é classificado como quente e úmido, com temperatura anual média de $30^{\circ} \mathrm{C}$, tendo como vento predominante o Nordeste com variação para o Sul. 

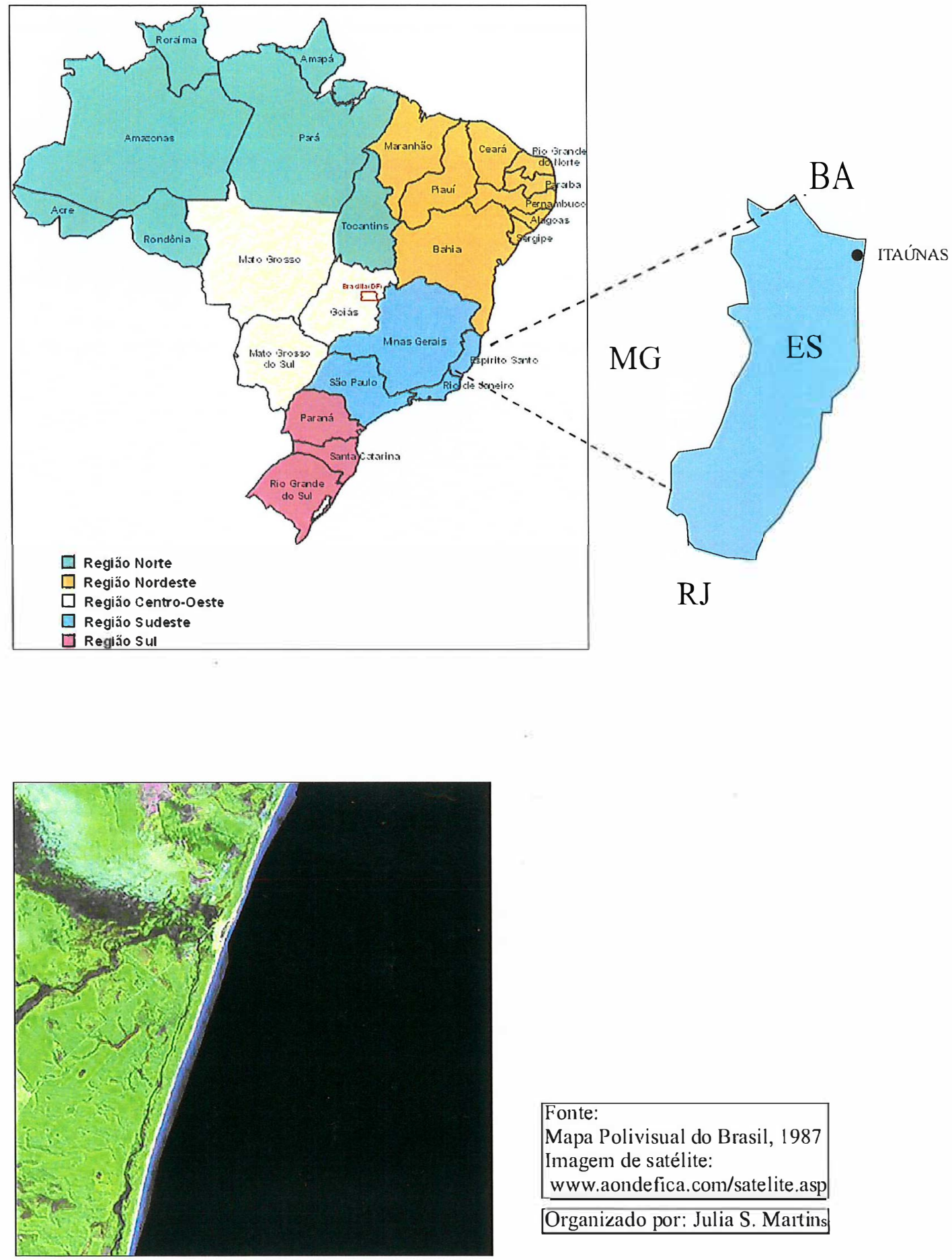

Fonte:

Mapa Polivisual do Brasil, 1987

Imagem de satélite:

www.aondefica.com/satelite.asp

Organizado por: Julia S. Martins

Figura 1-Localização da área de estudo 
No aspecto geomorfológico, a área de estudo, apresenta como principais acidentes de relevo, as dunas, o curso do rio, a existência de duas fozes e extensas áreas sujeito a alagamentos.

As dunas, do período Quaternário, são móveis sendo seu principal fator de formação e transporte, constituindo um modelado de origem eólica. $\mathrm{O}$ seu posicionamento e disposição encontram-se relacionados a duração de ventos atuantes na área.

Grande parte da área, se encontra sujeita a alagamentos temporários ou permanentes, estas características são responsáveis diretos por fatores de existência da ampla Planície Fluvial do rio Itaúnas, bem como o fato deste se apresentar na área de estudo, com baixa energia, formando meandros, o que permite que o mesmo saia com frequiência de sua calha principal, transbordando em suas duas margens.

A Vila de Itaúnas encontra-se localizada entre os limites do Parque Estadual de Itaúnas e pelos talhões de eucalipto.

\subsubsection{Parque Estadual de Itaúnas (PEI)}

O PEI é uma Unidade de Conservação de Proteção Integral, criada em 1991. Se localiza no distrito de Itaúnas, entre as coordenadas geográficas S18²4'00"e W39 $43^{\prime} 43^{\prime \prime}$, ocupando uma área de aproximadamente 3.650 hectares, sendo limitado ao Norte pela foz do Riacho Doce, que faz divisa entre os estados do Espírito Santo e Bahia, a Leste pelo Oceano Atlântico, a Oeste pelas plantações de eucalipto e ao Sul pela foz do rio Itaúnas.

A área do PEI está inserida dentro do bioma de Mata Atlântica, a qual ao longo de toda sua extensão, apresenta uma variedade de formações englobando um diversificado conjunto de ecossistemas florestais com estruturas e composições florísticas bastante diferenciadas, acompanhando as características climáticas da vasta região onde ocorre, tendo como elemento comum a exposição aos ventos úmidos que sopram do oceano. $\mathrm{Na}$ área onde está inserido o Parque, o bioma exibe ecossistemas como Mata de Tabuleiro, Restinga, Manguezal, Rios, Alagado, Dunas e Praia. 
A área do Parque está inserida na planície litorânea de deposição Quaternária, que se inicia na altura do rio Doce, caracterizada pela feição geomorfológica de dunas e circundada pelos tabuleiros de sedimentos terciários (IBGE, 1993). Apresenta os seguintes ecossistemas de Mata Atlântica: restinga, manguezais, dunas, praia, alagados e o rio Itaúnas. Este passa por oito municípios que compõem sua bacia hidrográfica. Seus principais afluentes são: córrego Angelin, rio Itauninhas, córrego Montanha, rio do Sul, córrego Caboclo.

O Parque atualmente, está inserido no Corredor Ecológico da Mata Atlântica, que interliga importantes fragmentos florestais do Espirito Santo e Bahia, aumentando a conexão entre eles, contribuindo assim para a conservação da diversidade biológica.

Quanto a vegetação encontra-se aquelas espécies associadas a Mata de Tabuleiro, de Restinga, de Alagados e Manguezais. A fauna apresenta animais como Capivara, Tatu, Lontra, Tamanduá-mirim, Paca etc.

Desde sua implantação, o PEI sofreu sete alterações em seu corpo técnico. Sendo o cargo de gerente ocupado na maioria das vezes por biólogos.

A sede do parque conta com uma biblioteca e uma exposição permanente de arqueologia, alojamento para pesquisadores e a Ecoloja com produtos confeccionados por moradores nativos, em parceria com o projeto TAMAR.

O parque formou algumas parcerias entre elas, com a Sociedade Amigos do Parque de Itaúnas (SAPI), criada em 1997 e tem como principal objetivo contribuir para a preservação do Patrimônio Histórico, Natural, Paisagístico, Científico e Cultural, do Parque, buscando a formação de uma consciência ambientalista, promovendo a melhoria da qualidade de vida das populações envolvidas na sua área de influência, através da proposta do desenvolvimento sustentável. Atua diretamente com projetos de artesanato, saúde e educação ambiental. Outra contribuição da SAPI, foi a criação da rádio comunitária de Itaúnas.

O parque conta também com parcerias de empresas e entidades para a realização de atividades de manutenção como a Aracruz Celulose e a Petrobrás.

Atualmente o PEI conta com dois guarda-parque. E um plano de manejo que foi financiado pela Petrobras. 


\subsubsection{Plantações de eucalipto no município de Conceição da Barra-ES}

Segundo Ferreira (2002), a chegada do eucalipto no extremo norte do Espírito Santo datam as décadas de 50 e 60 , com os objetivos de exportação de cavacos e produção de carvão para siderurgia, através das pioneiras Ouro Verde e ACESITA.

Na década de 70, mais precisamente no ano de 1976, a empresa Aracruz chega ao extremo norte do Espírito Santo, municípios de São Mateus e Conceição da Barra, expandindo seus plantios para a produção de celulose. Neste época algumas plantações de eucalipto já existiam, como as da propriedade da Ouro Verde, Acesita e Florestais Rio Doce. As áreas dessa última empresa foram vendidas em 1980 para a Bahia Sul (originária entre a CVRD e a Cia Suzano de Papel e Celulose).

Atualmente no município de Conceição da Barra atuam as empresas produtoras de celulose: Aracruz Celulose e Suzano Bahia Sul Papel e Celulose.

O município de Conceição da Barra possui área de $104.927 \mathrm{Km} 2$, desses a empresa Aracruz utiliza 27.300 hectares para plantações de eucalipto. De acordo com os dados do Relatório anual de 2003, a empresa Aracruz, é a líder mundial na produção de celulose branqueada de eucalipto e responde por $31 \%$ da oferta global do produto, destinado à fabricação de bens de alto valor agregado, como papéis sanitários, de imprimir e escrever e especiais.

Suas operações florestais alcançam os Estados do Espírito Santo, Bahia, Minas Gerais e Rio Grande do Sul, com aproximadamente 247 mil hectares de plantios de eucalipto, intercalados com cerca de 128 mil hectares de reservas nativas.

A capacidade nominal de produção de celulose da Aracruz, totalizando 2,4 milhões de toneladas anuais, está distribuída por duas unidades fabris: Barra do Riacho (ES) e Guaíba (RS).

No Espírito Santo, a Aracruz opera um complexo fabril de celulose totalmente integrado aos plantios e a um porto privativo especializado, Portocel, através do qual quase toda a produção da empresa é exportada. A Unidade Barra do Riacho reúne três fábricas com capacidade nominal total de 2 milhões de toneladas anuais de celulose. 
Segundo informações contidas no relatório anual de 2003 da empresa, o compromisso da Aracruz com o desenvolvimento sustentável se reflete nas práticas de manejo dos plantios de eucalipto e na preservação dos ecossistemas naturais. As práticas ambientais adotadas nas fábricas são também objeto de contínuos processos de aprimoramento. A responsabilidade social da Aracruz reflete-se, entre outros aspectos, nos diversos programas de ação social desenvolvidos com as comunidades localizadas na região de atuação da empresa.

O controle acionário da Aracruz exercido pelos grupos Safra, Lorentzen e Votorantim (28\% do capital votante cada) e pelo Banco Nacional de Desenvolvimento Econômico e Social - BNDES (12,5\%). As ações preferenciais da empresa, perfazendo $56 \%$ do total do capital, são negociadas nas Bolsas de Valores de São Paulo, Nova York e Madri.

Outra empresa que atuava no município de Conceição da Barra até o ano de 2001 era a Bahia Sul Celulose (BSC), a qual começou seu projeto na área no ano de 1985, em parceria da Cia Suzano de Papel e Celulose (CSPC) com a Cia Vale do Rio Doce (CVRD). Em 2004, ocorre a conclusão da integração da CSPC e da BSC surgindo uma nova Cia: a Suzano Bahia Sul Papel e Celulose, que atualmente atua em Conceição da Barra.

Segundo dados da empresa, a Suzano Bahia Sul Papel e Celulose possui uma área no município de 17.840 ha. Sendo a área de plantio com eucalipto de 10.902 ha (61\%), área de preservação da empresa de 5.791 ha, correspondendo a (32\%) e 1.147 ha (7\%) são de infra-estrutura.

Segundo o relatório anual de 2003 da Cia Suzano Bahia Sul Papel e Celulose, a empresa é uma das maiores produtoras integradas de papel e celulose da América Latina, com posição de liderança em vários segmentos do mercado. Sua capacidade de produção de celulose é de lmilhão de toneladas/ano. A empresa conta com três unidades de produção, duas localizadas em Suzano (SP), e outra em Mucuri na Bahia. Possui 269,8 mil hectares de terras próximas a unidade de produção, deste, 164,9 mil hectares estão disponíveis para plantios de eucalipto e a maior parte da área remanescente é permanentemente destinada a preservação ambiental. 
No trato das responsabilidades sociais a empresa realiza diversos projetos de atendimento e apoio a comunidade que estende desde projetos relacionados a educação, saúde, meio ambiente e qualidade de vida.

\subsubsection{Os primeiros registros de Itaúnas}

Através dos estudos arqueológicos realizados por Perota, citado por Ferreira (2002), nos sítios arqueológicos que pertencem à atual área do Parque Estadual de Itaúnas, pode-se afirmar que a história da ocupação humana em Itaúnas remete a quatro períodos distintos: o de caçadores e coletores de molusco que utilizavam a pedra lascada e polida; o período da agricultura, da pesca e da cerâmica; o períodó de contato dos primeiros europeus com a população indígena e a fundação da Vila de Itaúnas e o período de desenvolvimento da antiga Vila de Itaúnas.

Os primeiros registros documentados sobre Itaúnas, foram realizados pelo naturalista Maximiliano em sua viagem ao Brasil, entre os anos 1815-1817.

O naturalista e príncipe Maximiliano Wied-Neuwied, encontra-se entre as personalidades mais importantes que se destacaram na primeira metade do século XIX no âmbito da exploração científica do continente americano. Através de seus registros escritos e dos desenhos e pinturas realizados com nanquim e aquarela, quis transmitir uma imagem autêntica do Brasil, baseado nos fundamentos científicos utilizados no Velho Mundo no início do século XIX (Viagem ao Brasil..., 2001).

Em seus registros, Maximiliano descreve e retrata os índios Botocudos que habitavam a região de Itaúnas, também conhecidos por Aimoré ou Poxijá, como fortes e robustos, apresentando uma estatura média e uma caixa torácica larga e achatada na parte anterior. $\mathrm{O}$ tronco alongado, contrastando com as mãos e os pés pequenos, as pernas finas e o pescoço curto. A cor da pele variava do tom pardo passando por canela-claro a bronzeado. Os cabelos eram pretos, lisos duros e brilhantes. Tanto os cabelos, como a barba e os supercílios eram usados raspados.

Os botocudos, geralmente andavam nus. Porém, usavam muitos ornamentos corporais, como pena de aves presas à cabeça e em outras partes do corpo, colares de 
sementes ou frutos vistosos de cores ou de dentes de macaco e outros animais. Costumavam pintar o rosto com tinta extraída do urucum ou jenipapo. Perfuravam as orelhas e os lábios inferiores e usavam nesses orifícios madeiras leves e talhadas. Suas moradias eram simples, feitas de folhas de palmeiras (Viagem ao Brasil, 2001). Eram índios muito fortes e foram os que ofereceram maior resistência aos brancos do século XVI ao XIX.

Ferreira (2002), destaca também que o naturalista em sua caminhada pela região entre Bahia, Rio de Janeiro e Minas Gerais, descreve o trecho que vai do rio Doce em Linhares, atual Estado do Espírito Santo ao rio Alcobaça na Bahia, dando testemunho das características dessa região, farta em floresta, água, alimento.

Outro dado importante registrado por Maximiliano, segundo fontes do PEI, a região de Itaúnas era uma fazenda e pertencia ao Ouvidor da Comarca de Porto Seguro, Marcelino da Cunha. Nesse local viviam poucas famílias de índios e negros, que se agrupavam em uma choupana e que tomavam conta do gado.

Nessa época já se fazia presente a exploração de madeira e tinha-se na mandioca o principal produto agrícola cultivado da região, que através da farinha era comercializado em regime de troca.

\subsubsection{Fragmentos de memórias: a Vila de Itaúnas sob a areia}

O local onde era a fazenda de gado, com o passar do tempo, cedeu lugar ao nascimento da antiga vila de Itaúnas. O crescimento da antiga Vila se deve a vinda da Coroa e a subsequente expansão territorial da sociedade brasileira na primeira metade do século XIX. O surgimento da Vila data 1750-1800 d.C.

$\mathrm{Na}$ Vila antiga, havia uma população miscigenada de índios, negros e europeus, que tornou o lugar um importante entreposto de comercialização de madeira e de farinha. Segundo Ferreira (2002), do porto da Vila saíam grandes canoas, com capacidade para 50 a 60 sacas de farinha, que as transportavam até a cidade de Conceição da Barra. Esse fato pode ser evidenciado no relato de uma moradora de Itaúnas: 
“(...) tinha muitos canoeiros, meu pai também, que iam com canoa de 50, 60 sacos, levava com farinha e trazia os materiais que precisava, carne seca (...)"'(moradora de Itaúnas, 83 anos).

Através de dados do PEI e dos fragmentos de memória dos antigos moradores de Itaúnas, foi possível reconstruir o cenário da antiga Vila. Assim, nas Itaúnas velha, forma como é chamada a antiga Vila pelos nativos, além das casas dos moradores, havia um pequeno comércio, uma escola, uma igreja, um cemitério um porto e uma cacimba. A Vila era também o local de festas religiosas e dos bailes de forró, dos quais as pessoas que moravam nas roças vinham participar.

Segundo Petroff (2003), a população nessa época era composta por integrantes de quatro famílias, sendo o ambiente natural caracterizado pela densa floresta atlântica, com um conjunto de rios e alagados e com uma fauna e flora riquíssima.

Nesse ambiente de alta diversidade de recursos, a população local desenvolvia um modo de vida considerado tradicional, baseado no uso comunal e extrativista do território e dos recursos naturais. No território de uso comum, a população humana local manejava os recursos do ambiente natural e supria grande parte das necessidades de subsistência, obtendo água, peixes, carnes, frutos, madeira, cipó, raizes e ervas medicinais (Ferreira, 2002).

Outro ponto referente à história da região, está relacionado às raízes quilombolas. Segundo fontes do Koinonia (1998), uma Instituição Ecumênica, que desenvolve projetos com populações remanescente de quilombos e populações excluídas social e economicamente, localizada na cidade do Rio de Janeiro, a região Norte do Estado do Espírito Santo era conhecida como a região do Sapê do Norte, sendo habitada historicamente por negros. Durante o regime de escravidão os escravos fugidos iam para essa região, formando núcleos de resistência, sendo considerados pelas autoridades locais, verdadeiros quilombos. A memória desse passado está expressa em narrativas ou nas formas de cantos e rituais de manifestação, como as brincadeiras do Ticumbi, Jongo, entre outras realizada em Itaúnas até os dias atuais. 
Segundo os moradores, a Vila antiga de Itaúnas, situava-se na restinga entre o rio e mar, por motivo da retirada da vegetação de restinga, fixadora do solo arenoso, as dunas avançaram e sobre a Vila e a cobriram. Desse modo, todo o antigo cenário e configuração espacial que dava lugar para a população humana habitar, viver, trabalhar, alimentar-se, a partir de 1940 começa a desaparecer, através do processo de soterramento que levou 30 anos para se efetuar e soterrar definitivamente na década de 70, a antiga Vila de Itaúnas.

Esse fenômeno se faz presente até hoje no imaginário dos moradores e através da memória do passado, narram como aconteceu:

"Na beira do mato começou criando aquele muludu de areia, foi crescendo igual formigueiro. Assim começou que a areia foi crescendo e o vento foi jogando, primeiro que atingiu foi a igreja. A areia foi chegando no meio da cidade e não chegou rapidinho não. Custou, custou, a areia vinha chegando e o povo falava: a areia vem chegando ai. E a gente ia tirando devargarzinho, a gente foi mudando e vindo para cá (local da nova vila). Aqui era fazenda de criação de gado" (morador de Itaúnas, 73 anos).

É importante destacar que os moradores locais desenvolveram várias lendas para explicar o soterramento da antiga vila, a forma de representação simbólica desse fenômeno natural pode ser evidenciado nos dois relatos de moradores descritos abaixo:

"Eles falam uma coisa, que Itaúnas velha que foi o seguinte, o São Benedito, fecharam a porta para São Benedito, assim ele mostrou aquele castigo ali"(Morador de Itaúnas, 73 anos).

"Muitos fala que foi uma senhora que era crente e tinha esse negócio de folia de santo que vinha do norte para ca, então os foliões chegavam ficavam na praia para vim até o delegado, o delegado autorizar para entrar na cidade, então a mulher era crente e o marido dela não estava aí, ai ela desconjurou a santo e disse que não queria aquele pau na cidade. Ai eles voltaram e tudo bem, nós vamos embora e nunca mais vamos voltar aqui, dessa vez a areia 
foi chegando, chegando, primeiro enterrou a igreja $e$ assim por diante..." (moradora de Itaúnas, 56 anos).

Consumado o processo de soterramento, a antiga Vila de Itaúnas que ficou sob a areia, é ainda hoje, lembrada na memória e nas estórias dos moradores mais antigos, misturados com sentimentos de dor, perdas, saudades, nostalgia e à impossibilidade de visitar seus ancestrais. Vale lembrar que as marcas do passado não são somente materiais, mas sobretudo estão presentes nas representações simbólicas.

\subsubsection{O início da nova Vila de Itaúnas}

Após o soterramento da antiga Vila, não sobrou outra alternativa para a população nativa a não ser, mudar para o outro lado da margem do rio Itaúnas e construir no local a nova Vila. Este local era abastecido por uma cacimba e onde ainda não havia energia elétrica. Era uma antiga fazenda de gado que foi comprada pela Prefeitura de Conceição da Barra e doada para os moradores construírem suas casas. Nascia então uma nova Vila. (Petroff, 2003 e Ferreira, 2002).

A nova Vila de Itaúnas era em seu início, formada por uma comunidade constituída basicamente por famílias de pescadores, agricultores, coletores e alguns comerciantes. Segundo Rebello \& Foëger (2002), esses moradores antigos viviam da produção de farinha, do cultivo da terra, da caça e da pesca artesanal.

"Quando o pessoal, mudou para cá (vila nova), foi outro destino. Uns vendiam o terreno, foram vendendo para as firmas, é onde hoje é eucalipto, e onde se vê eucalipto era do pessoal, do povo nativo, foram vendendo e as firmas foi comprando e desmatando. Aonde é eucalipto daqui para a Barra tudo era a gente que morava por aqui" (morador de Itaúnas, 72 anos).

(...) "pois é, nossa Itaúnas quando mudou para cá (nova Vila), tudo mudou"(...) (moradora de Itaúnas, 83 anos). 
Através dos registros e dos relatos acima, comprova-se que na década de 70 , quando a nova Vila estava se formando, concomitantemente estava se implantando a agroindústria papeleira, trazendo consigo a lógica do mercado e acarretando mudanças no território e consequentemente ao modo de vida da população local. Nessa época a Vila começa a receber alguns visitantes e pesquisadores curiosos com o fenômeno de soterramento da antiga Vila.

\subsubsection{Infra-estrutura da Vila de Itaúnas}

Em campo, pode-se constatar que atualmente no que tange a infra-estrutura, a Vila de Itaúnas, dispõe de abastecimento de água. Sendo a captação e distribuição realizados pela CESAN (Companhia espírito-santense de saneamento).

Quanto ao esgoto, existe apenas fossas familiares, não sendo realizada a coleta. Tais condições de esgotamento sanitário favorecem a contaminação do lençol freáticos e do rio. Contudo, segundo fontes do PEI, o terreno arenoso existente na região permite redução dos impactos dos lançamentos dos esgotos sanitários, pelo fato de camadas de areia poderem funcionar como filtros biológicos naturais. $\mathrm{O}$ índice de coliformes fecais são inferiores ao limite suportável.

Quanto a coleta do lixo esta não é seletiva, sendo realizada pelo poder público local. Cerca de $15 \mathrm{~m} 3$ de resíduos sólidos são produzidos por dia e na temporada esse número passa para $45 \mathrm{~m} 3 / \mathrm{dia}$.

Itaúnas ainda conta com o serviço de linhas telefônicas desde o ano de 2001; e transporte coletivo que liga a Vila as roças e a cidade de Conceição da Barra.

Inaugurada nesse ano, Itaúnas passou a ter a Casa do Cidadão, que oferece serviços como Correio, Conselho Tutelar, serviços jurídicos e o IDAF (Instituto de Defesa Agropecuária e Florestal).

$\mathrm{Na}$ Vila não há agências bancárias e tão pouco caixas eletrônicos. Contam com uma farmácia, dois mercadinhos e duas padarias pequenas. 
Existe também um posto de saúde e atendimento odontológico. Itaúnas ainda conta com duas escolas a Ciranda Cirandinha - pré-escola e a Escola Estadual Benônio Falcão Golveia, que atende alunos do ensino fundamental e médio.

Quanto as ruas da Vila, estas não contam com nenhum tipo de pavimentação, no entanto são bastante arborizadas e possuem latas de lixo grandes.

Constatou-se em campo que a Vila de Itaúnas nas últimas décadas passou a dispor de melhorias tanto na infra-estrutura básica, como também acesso a educação.

\subsubsection{Breve perfil dos moradores de Itaúnas}

Verificou-se em campo, que a grande maioria dos entrevistados residentes em Itaúnas, tem casas de alvenaria que se distribuem entre 4 e 5 cômodos. São casas simples, mas muito organizadas e limpas. A maioria dos moradores adquiriu eletrodomésticos e contam com linha telefônica.

Quanto ao nível de escolaridade apenas os mais velhos são analfabetos, o restante apresenta níveis diversos de escolaridade.

Quanto a dieta alimentar, constatou-se que a maioria dos moradores possuem uma dieta básica, baseada em gêneros alimentícios como peixes, feijão, farinha, mandioca e arroz. O peixe é o principal alimento entre essa população. A dieta ainda é complementada com galinhas caipiras criadas soltas.

Quanto ao uso dos quintais domésticos, observou-se que os moradores fazem desses diferentes tipos de uso. Cria-se galinhas, fazem pequenas plantações de mandioca e ervas medicinais e a outros utilizam-no como camping para turistas. 


\section{RESULTADOS E DISCUSSÃO}

\subsection{A fragmentação do território e os diferentes usos e apropriações: conflitos e interferências no modo vida decorrentes desse processo}

Durante o transcorrer desta pesquisa pode-se evidenciar em Itaúnas e adjacências, um processo de sobreposição no uso do território, consubstanciado por apropriações privadas e estatais. Estas contribuíram para alterar a estrutura agrária e a configuração espacial, causando interferências no modo de vida da população local, no que se refere aos aspectos ecológicos (manejo e conservação de recursos naturais), socioculturais (relações de parentesco) e econômicos (modo de produção e atividades de subsistência).

Através de registros históricos e relatos de moradores de Itaúnas, foi possível analisar os diferentes usos e apropriação do território e os conflitos decorrentes desse processo, levando-se em consideração a questão do tempo e espaço.

Durante o período que se estende do início século XIX até meados do século XX, onde se encontram os primeiros registros da presença de populações até a exploração da terra em grande escala pela indústria papeleira, o ambiente, permaneceu preservado, mesmo sendo utilizado pela população local, em suas práticas produtivas e culturais.

O uso que a população humana fazia do território e dos recursos se dava de forma comunal, a qual só pode ser entendida dentro de uma lógica ampla de reprodução social e cultural, distinta da existente na sociedade urbano-industrial.

$\mathrm{O}$ acesso à terra e aos recursos de uso comum população local, e estendiam-se a uma extensa teia de relações de parentesco, de 
compadrio, de ajuda mútua, de normas e valores internos que privilegiam a solidariedade do grupo.

Também constado por Ferreira (2002), as atividades de subsistência dos moradores eram supridas fortemente por meio da interação com o ambiente natural, constituído da floresta firme, dos alagados e do mar. As atividades de subsistência se dividiam entre a pesca artesanal, realizada tanto no rio como no mar, a caça, a coleta de frutos, cipós, lenhas e ervas medicinais e a pequena agricultura. No relato do morador abaixo é possível perceber elementos que indicam a forma comunal de acesso ao território e aos recursos.

"Antes o povo era bem à vontade você entrava no mato e caçava, fazia roça, criava animal, tudo junto. Eu tenho 50 anos e nunca vi o povo acabar com mata aqui, a gente precisava dela. Meu pai tinha 30 alqueires de terra e não tinha 2 plantado de mandioca" (morador 50, anos).

Nessa época, as residências eram em sua maioria feitas com materiais locais e com custo muito baixo. A técnica empregada na construção das casas era tradicional, chamada de taipa-de-mão, onde as paredes são feitas de barro socado entre tábuas ou ripas. As casas não tinham muros nem cercas que as separavam. E o modo de vida era representado pela tranqüilidade da ausência de cercas entre as casas e pelo uso comum que faziam de grandes extensões de florestas, brejos, rios, córregos e mar.

Porém, todo esse cenário a partir da década de 70 começa a ser transformado, uma vez que as terras do estado do Espírito Santo, principalmente aquelas localizadas no extremo norte, passam por uma invasão estratégica e comercial de plantações de eucalipto. Este último, uma espécie exótica original da Austrália é plantado em países como Brasil, Chile, Tailândia, Índia entre outros, com a finalidade de extrair a celulose, matéria-prima fundamental para a fabricação de papel e para a produção de carvão vegetal, madeira serrada, compensados, aglomerados e chapas e entre outros.

No Brasil, os grandes plantios com fins silviculturais ganham espaço, por meio de incentivos fiscais do governo, como no Plano Nacional de Desenvolvimento do governo Geisel, no ano 1974. Conjugando-se tais incentivos às condições favoráveis que o Brasil 
apresentava, como características ecológicas favoráveis, disponibilidade de terras e mãode-obra barata, as agroindústrias se fixaram em solos brasileiros e passaram a explorar a terra de forma pouco sustentável.

No caso do estado do Espírito Santo que tinha originalmente coberto pela floresta de Mata Atlântica, em torno de $90 \%$ do seu território, com os incentivos fiscais federais, os reflorestamentos homogêneos foram amplamente disseminados durante o período de 1967 e 1986, fato de vital importância para a consolidação do pólo industrial de celulose no estado.

Em 1975, existiam cerca de 98 mil hectares reflorestados no Espírito Santo, representando 2,1\% da área total do estado. Esta área praticamente dobrou num período de 20 anos. Em 1995 o estado registrava mais de 172 mil hectares reflorestados. No período compreendido entre os anos de 1975 e 1995, houve um crescimento médio anual na área reflorestada do estado da ordem de 2,9\% (Plano estratégico para agricultura capixaba, 2003).

No município de Conceição da Barra, pode-se evidenciar por meio dos dados apresentados na Tabela 1, o impulso dado à silvicultura empresarial e à agroindústria, a partir de 1975, em virtude dos incentivos fiscais do Governo Geisel. Sendo o período compreendido entre os anos 1975 e 1980, os que registram maior expansão da monocultura de eucalipto na área do município.

Tabela 1. Área plantada de eucalipto no município de Conceição da Barra (área/ha)

\begin{tabular}{llll}
\hline Atividade/ano & 1975 & 1980 & 1985 \\
\hline Silvicultura & 15.070 & 45.316 & 22.855 \\
\hline
\end{tabular}

Fonte: adaptado de Ferreira (2002).

Para implantar as grandes áreas de reflorestamento de eucalipto, as empresas multinacionais como a Aracruz Celulose e outras com capitais estrangeiros provenientes dos países industrializados, estabeleceram-se no solo do estado, principalmente no 
extremo norte deste, comprando estrategicamente terras de populações que muitas vezes por serem descendentes de escravos e indígenas nunca as escrituraram. Essa necessidade de aquisição de grandes áreas para o plantio, interferiu na estrutura fundiária da região. Dessa forma, tais plantações de eucalipto em grande escala sobrepuseram-se ao território das florestas nativas e às terras comunitárias.

No processo de implantação da monocultura de eucalipto no município de Conceição da Barra, muitos moradores tiveram suas terras compradas pelas empresas. Todo esse processo de consolidação e exploração da terra pela cultura do eucalipto, provocou não apenas alterações ambientais, como perturbações no modo de vida da população local.

As evidências dos impactos e os conflitos decorrentes da atividade madeireira, foram colhidas nos relatos e depoimentos dos moradores, que muitas vezes se faziam como desabafos nas conversas e em importantes trabalhos científicos, os quais serviram de base para ampliar e fundamentar ainda mais a discussão em torno da questão.

Um dos primeiros pesquisadores a tratar do assunto, foi o naturalista capixaba Augusto Ruschi. Este desde a década de 70, desenvolveu pesquisas pioneiras sobre os impactos da monocultura de eucalipto. Desde essa época esse pesquisador, já anunciava que o eucalipto transformaria grande parte do que restava da Mata Atlântica capixaba em Deserto Verde, ocupando não só o que era Mata Atlântica, como também o melhor das terras para agricultura e pecuária (Coimbra, 2002).

Ferreira (2002), em sua dissertação, também contribuiu para este debate, em questão, uma vez que evidenciou e discutiu os impactos da monocultura de eucalipto, na região de Itaúnas, principalmente no que se refere às questões socioambientais.

O geógrafo Aziz Ab'Saber (2001), em um seminário internacional sobre eucalipto e seus impactos, discutiu sobre a ética do futuro das empresas envolvidas com a cultura do eucalipto. Em seu discurso, afirma que no trato das questões socioculturais e ecológicas, os impactos negativos dessa atividade alterou unilateral e decisivamente a geografia natural e humana dessa faixa do território do Espírito Santo. 
No trato das questões ecológicas, a indústria papeleira acabou devastando grande área de vegetação nativa, causando grande perda da biodiversidade animal e vegetal do bioma Mata Atlântica.

Segundo Ferreira (2002), com a destruição da floresta, a elevada diversidade biológica foi drasticamente diminuída, alterando assim cadeias alimentares, bem como um vastíssimo banco genético cujo potencial permanece pouco conhecido.

Mora e Garcia (2000), descrevem os impactos da cultura de eucalipto e assim relatam que vários plantios de eucalipto ocuparam terras em locais não recomendados, ou seja, áreas aptas para a agricultura, encosta íngremes, margens de rios e outras. Além disso, no aspecto biológico, afirma que os primeiros projetos de implantação não consideraram os planos de manejo para a garantia da biodiversidade dos sistemas aquáticos e terrestres, com conseqüência até os dias atuais.

Outro impacto percebido também pelos moradores, nesse processo de sobreposição da mata nativa pela plantação de eucalipto, foi o aniquilamento e(ou) poluição por agentes químicos de muitos corpos d'água, os quais fazem parte da bacia hidrográfica do rio Itaúnas, um dos maiores e principais mananciais do Espírito Santo.

Quanto às questões sociais e econômicas, a implantação da atividade madeireira, por um lado favoreceu a economia local, gerando empregos para os moradores de Itaúnas. Porém, com o passar do tempo, com a avanço da tecnologia e o aumento da mecanização, esse quadro se alterou e muitos trabalhadores do campo perderam seus empregos.

Para os moradores de Itaúnas, a destruição da floresta nativa representa a perda do território de uso comum, ou seja, do espaço que era utilizado pela população para práticas de subsistência e manutenção da vida. Neste contexto, os impactos atingiram o modo de vida e o modo de reprodução social da população local.

"Antes de chegar as firmas, eu me lembro bem como era. Era muita mata, mata daqui mesmo (nativa), onde o povo ia para caçar, para comer, mesmo. Muita coisa a gente tirava da mata. Então, naquela época não tinha trabalho, não, as casas que a gente tinha era feita quase tudo com coisa da mata também. Minhas irmãs trabalharam nas firmas, mas 
depois ficaram tudo sem emprego e a gente rodeado de eucalipto " (moradora nativa de Itaúnas, 46 anos).

O depoimento acima, apresenta elementos que sustentam ainda mais as afirmações sobre as interferências da implantação da monocultura no território e no modo de vida da população local, principalmente no que se refere às atividades de subsistência. Mora e Garcia (2000), afirmam que em alguns empreendimentos florestais, em regiões isoladas, como é o caso da área em questão, a estabilidade da população humana com relação às práticas produtivas e culturais é sempre afetada, ficando parte desta dependente das ações das empresas. Uma vez que a política empresarial, traz mudança na origem e na quantidade de alimentos produzidos em certas áreas, em função da substituição parcial das culturas agrícolas por eucalipto.

Conforme pode-se perceber, as empresas do setor privado, foram responsáveis por transformar e fragmentar grande parcela do território a que estamos nos referindo. $\mathrm{O}$ papel do governo nesse contexto fica sendo o de regulador. No entanto, o mesmo deveria utilizar seus instrumentos para assegurar um uso racional do ambiente. Ao contrário disso, evidenciou-se que o governo estimulou esse tipo de atividade com incentivos fiscais. Dessa forma, o território passou a ser apropriado com fins empresariais e comerciais. Face ao exposto, concorda-se com Capra (1982), quando este expõe a idéia de que a visão mecanicista do mundo, apoiada pelo paradigma cartesiano, exerce forte influência nas entidades governamentais, servindo como fundamento lógico para o tratamento do meio ambiente, como se este fosse formado por peças separadas a serem exploradas por diferentes grupos de interesse.

Capra (1982), ainda afirma que a tecnologia produzida por algumas empresas, que têm por meta o controle, a produção em massa e a padronização, busca um crescimento ilimitado em sua produção, perturbando seriamente os processos ecológicos que sustentam o ambiente natural e que são a própria base de nossa existência. No âmago dessa questão, como de costume, estão a miopia econômica e ganância empresarial.

No caso do Brasil, percebe-se que há um uso privilegiado do território em função das forças hegemônicas representadas pelas empresas estatais. Estas, por meio de suas ordens, comandam o território e a vida social, relegando o Estado a uma posição de 
testemunha. Nesse contexto, o território acaba sendo fragmentado causando um desequilíbrio na manutenção dos ecossistemas e no modo de vida da população humana que dele depende e nele reside.

O processo de apropriação do território na unidade empírica da pesquisa, continuou se desenvolvendo e se concretizou também sob a lógica do Estado, no ano de 1986, com o tombamento das dunas, pelo Conselho Estadual de Cultura, como Patrimônio Histórico Paisagístico e Cultural e mais tarde, no ano de 1991, com a implantação do Parque Estadual de Itaúnas (PEI) - Unidade de Conservação de Proteção Integral, pela Secretaria de Estado para Assuntos do Meio Ambiente (SEAMA-ES).

A criação da Unidade de Conservação deveu-se -de início a um movimento realizado em prol da conservação das características ambientais e culturais do local e também como estratégia para impedir a construção de um hotel resort na selvagem praia de Itaúnas, interesse de um grupo de empresários da região. Outros motivos que propiciaram a criação da área de conservação, foram os riscos de uma ocupação desordenada, a contínua degradação dos ecossistemas de Mata Atlântica e a presença de sítios arqueológicos.

O Parque Estadual de Itaúnas é uma área destinada à preservação ambiental delimitada geograficamente, dotada de belezas cênicas e atributos naturais excepcionais. Constitui-se como bem do Estado e tem como finalidade atender fins científicos, . culturais, educativos e recreativos, sendo seu principal objetivo, a preservação de ecossistemas locais e da diversidade genética, conforme consta no Decreto de lei $\mathrm{n}^{\circ}$ 4.967-E, de 08 de novembro de 1991, explicitado abaixo:

“Artigo 20 - O Parque Estadual de Itaúnas tem por finalidade resguardar os atributos excepcionais da natureza, na região, a proteção integral da flora, da fauna, do solo, dos rios, das áreas de alagados e alagáveis, das dunas e dos demais recursos naturais, bem como a sua utilização para objetivos educacionais, recreativos e científicos como o desenvolvimento do Projeto Tartaruga Marinha". 
Destaca-se que o modelo adotado pelas gestões do PEI, seguindo a visão predominante dos órgãos de preservação, os quais enxergam o meio natural por si só, não reconheceu como relevante em sua implantação, a existência da população local, com sua cultura e a sua forma de relacionar-se com o meio. Na política de manejo do parque, algumas atividades praticadas pela população local foram proibidas, como no caso da caça, do roçado, da extração de lenha, ervas medicinais e outros produtos da mata, da coleta de frutos etc. Conforme pode ser evidenciado pelos depoimentos que se seguem:

"Antes as pessoas caçavam e viviam, né? Assim, matava uma caça, né? Para comer, para comer mesmo, ninguém precisava vender não, era para o alimento da família. Ai isso ai foi privado e ninguém pode mais fazer. Nem madeira pode tirar. Hoje nem uma lenha a gente não pode mais fazer, antigamente a gente fazia e economizava até o dinheiro do gás, com o absurdo que o gás está hoje, né? Então hoje nem isso a gente pode fazer mais" (morador nativo 52 anos).

Então, tinha gameleira grossa, muita fruta. Antigamente tinha muito passarinho, tucano, "maritaca, aracuã até jacutinga tinha nessa beirada de praia. Ai a turma ia para lá do tempo que não era proibido, as vezes ia para lá, as vezes 6 da tarde, 6 da manhã, era hora dos passarinhos comer e ia para lá, para atirar, para matar, para comer, a gente precisava para comer mesmo.

Com o parque mudou porque naquela época na Itaúnas velha, não existia o negócio de parque, era diferente. Agora o parque entrou ai dentro, a gente sentiu algumas coisas. Numa parte melhorou e as vezes a gente pensa assim que noutra parte as vez não melhorou, não, mas essa parte que a gente acha que não melhorou, não é por isso, é que naquela época tudo era liberado as vez tinha uma caçinha. Negócio de uma caça a pessoa matava, não tinha esse negócio de embargação, e hoje não, hoje não pode, hoje não pode caçar não pode matar os bichos. Antes era para comer não tinha esse negócio de caçar para vender, não era para vender, era só para as despesa de casa" (morador nativo 72 anos). 
As Unidade de Conservação, são áreas de fundamental relevância para preservação de ambientes naturais, ainda mais em Itaúnas, local de importância ressaltada pela riqueza dos recursos naturais e por possuir ecossistemas associados à Mata Atlântica e sítios arqueológicos. No entanto, tem-se a intenção de discutir aqui a maneira como o órgão de Itaúnas é administrado em relação à participação e à inserção da população local nas discussões de manejo dos recursos. Uma vez que a política de gerenciamento da Unidade de Conservação, deveria ter como pressuposto a integração e participação da população, nas tomadas de decisão e não a exclusão dessa.

O que se faz necessário atualmente, é a busca por novos paradigmas para a relação ser humano e natureza, onde se estabeleça uma política de conserzação mais democrática e participativa, reconhecendo também como importante o vasto conhecimento empírico que as populações possuem do ambiente que os cercam.

Begossi, et. al., (2004), salientam que no Brasil, ainda impera o manejo imposto pelo governo, onde as estratégias de manejo são definidas por cientistas e agências governamentais. Uma alternativa para resolver tal problema, seria envolver as comunidades locais em estratégias de co-manejo, onde a população seria consultada e participariam na decisão e estratégias de manejo a serem adotadas.

Em Itaúnas, a conjugação de características naturais, representada principalmente pelas dunas e pelo contraste das mesmas com as áreas de alagados, associando-se ainda às suas praias e também pelas características culturais, destacando os sítios e monumentos históricos, as manifestações folclóricas, artesanais e culturais, criou-se um ambiente atrativo para o turismo. Os primeiros fluxos de turismo no local datam da década de 70, mas em quantidade ainda bastante reduzida. Na década seguinte, anos 80 , esse fluxo começa a aumentar, sendo o local procurado principalmente por pesquisadores, universitários e aventureiros. Ainda nesse período, década de 80 , além do baixo fluxo, as interferências e a pressão na configuração espacial da Vila foram pouco notadas.

De acordo com o Plano de Ordenamento da Vila, Governo do estado do Espírito Santo (2001), no final da década de 80, existiam na pequena Vila 156 residências de uso permanente e 87 residências sazonais. Nessa época, o baixo fluxo de turistas era também 
evidenciado com o número de pousadas existentes, 5 e 20 outros estabelecimentos comerciais diversos.

No final da década de 90 e nos três primeiros anos do século XXI, o fluxo turístico aumenta vertiginosamente. Tal aumento acelerado do turismo se deve à elevada divulgação do local nos meio de telecomunicação e também à coexistência de diferentes tipos de turismo como o ecoturismo, o de massa e o turismo da juventude, este último formado por pessoas jovens que procuram a Vila em busca do forró, que passou a ser um importante atrativo local, principalmente no mês de julho, quando acontecem o Festival Nacional de Forró e o Circuito de Forró.

A exploração do turismo em Itaúnas no decorrer dos anos, passou a ser mercantil. Dessa forma, desenvolveu-se sem a criação de mecanismos de controle, ou seja, sem um planejamento adequado para esse tipo de atividade, fato que acarretou modificações desordenadas na organização e configuração espacial da Vila e interferências no modo de vida da população local.

Segundo dados da organização não governamental Sociedade Amigos do Parque de Itaúnas (SAPI), no verão de $97 / 98$, o número de turistas chegou a 20.815 e no verão seguinte 98/99, esse número aumentou para 52.031 visitantes.

Junto com os turistas, vieram também os investidores de vários locais do Brasil, trazendo para Itaúnas investimentos de pequeno e médio porte, incrementando o comércio local com a construção de pousadas, restaurantes e bares. Os moradores locais influenciados e iludidos com a valorização imobiliária, passaram a vender suas casas, sendo muitas destas transformadas em pousadas. Dessa forma, alto índice de coabitação é percebido na Vila, ou seja, mais de uma família habitando uma mesma casa.

No bojo do processo de modificação da configuração espacial, notam-se alterações em Itaúnas, quanto ao uso do solo no perímetro urbano, o que provocou uma descaracterização das antigas construções, alterando o aspecto bucólico da Vila de pescadores e acentuando ainda mais o processo de estratificação do território. A parte central da Vila se torna mais valorizada pela especulação imobiliária, tornando muitas residências locais em pousadas, restaurantes e lojas e afastando os moradores para áreas 
mais retiradas. A tabela 2, ilustra o processo de evolução no uso do solo no período entre 1996 e 2001, período em que foi evidenciado o maior fluxo de turistas.

Tabela 2. Evolução do uso do solo (tipo de edificação) na Vila de Itaúnas 1996 - 2001

\begin{tabular}{llll}
\hline Uso do solo & Ano de 1996 & Ano de 2001 & Crescimento em \% \\
\hline Residência local & 156 & 205 & $31 \%$ \\
Residência sazonal & 87 & 102 & $17 \%$ \\
Pousada & 5 & 50 & $900 \%$ \\
Estabelecimentos comerciais & 20 & 71 & $255 \%$ \\
Institucional & - & 15 & - \\
Lazer & - & 3 & - \\
Vazio & 82 & 23 & decréscimo em 71\% \\
\hline
\end{tabular}

Fonte: Plano de ordenamento da Vila de Itaúnas (2001).

Por meio dos dados apresentados na tabela 2, representada acima, pode-se observar a partir do ano 2001, a predominância de residências locais seguida pelas residências sazonais, ficando o número de estabelecimentos comerciais em terceira posição.

Porém, se quantificarmos o número de uso comercial somado ao número de pousadas, o total de estabelecimentos será de 121, ficando em segundo lugar na predominância do uso do solo, conforme representado no gráfico abaixo. 

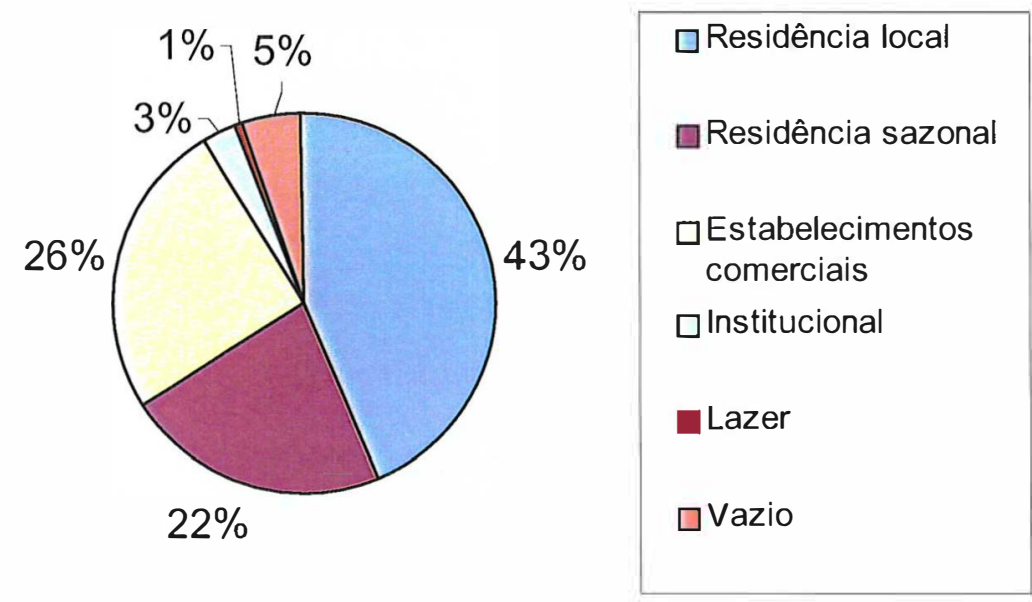

Figura 2 - Uso do solo na Vila de Itaúnas

$\mathrm{Na}$ concepção de muitos moradores, o aumento do número de estabelecimentos comerciais introduzidos em seu território, por pessoas de fora, que não são nativos, trouxe mudanças para a economia local, excluindo-os da apropriação da renda gerada pela atividade turística. Esse fato pode ser evidenciado no relato abaixo, de uma moradora, o qual apresenta também outros elementos que confirmam a forte especulação imobiliária em Itaúnas:

"As pousadas, realmente estão acabando com os nativos, realmente quem tem pousadas aqui, não é daqui. Tem nativo que tem seu imóvel, precisa do dinheiro, ele tá passando por uma situação dificil, ele desfaz daquilo, quer dizer, o próprio nativo não tem dinheiro para comprar, mas quem vem de fora tem dinheiro. Compra ali, é uma casa, mete o pau, quebra. Daqui dois, três, quatro meses você vai lá, já tá aquela pousadona dentro. Então, os ganho são do próprio povo de fora. Então, quer dizer, vem naquele período dos três meses de verão ou dois meses, vem naquele periodo trabalhou ali quando juntou o dinheiro, lugar deles, quer dizer, isso faz falta para o nosso lugar. Ganha o dinheiro aqui e não gasta o dinheiro aqui. O homem da pizzaria, ele é de fora, ele veio, comprou aquele terreno ali, dois lotes era. Ai 
comprou os dois lotes por 60.000 reais, quer dizer, agora ele fez a pizzaria do lado de cá e partiu o lote no meio e vendeu um lote e ficou com um lote e sabe o valor que ele vendeu? Por 60.000. Agora ele nem mora mais aqui, mora em São Mateus, só vem num feriadinho deste. Trabalhou vai embora" (moradora nativa 31 anos).

Embora consideremos as mudanças negativas ocorridas na estrutura da Vila de Itaúnas, em virtude do incremento do turismo, por outro lado, esse tipo de atividade trouxe geração de renda e ocupações temporárias para a população local, seja na oferta de mão-de-obra, nas atividades ligadas diretamente ao turismo como pousadas, bares, restaurantes, artesanato e outros, seja na construção civil. Ressalta-se que esse fenômeno foi mais acentuado nos anos em que esta atividade se desenvolvia em maior escala, ou seja, entre os anos 1998 e 2002.

Atualmente, a Vila de Itaúnas vem sofrendo um processo de crise com relação ao turismo. Nas entrevistas realizadas, muitos moradores se queixam da queda do número de turistas, desde o "verão" de 2003. A crise ainda é agravada em virtude do grande número de estabelecimentos comerciais, que oferecem tipos de serviços como pousadas $\mathrm{e}$ restaurantes, gerando concorrência entre os comerciantes locais.

Embora haja elementos nos discursos dos moradores que indiquem a crise do turismo em Itaúnas, a renda gerada por esta atividade, principalmente nos anos de maior pico, somada aos benefícios concedidos a muitos pescadores na época de defeso, levaram ao aumento do poder aquisitivo. Esse fato propiciou melhoras nas condições de moradia. As casas de muitos moradores foram sendo modificadas e até certo ponto melhoradas para atender aos turistas. Percebe-se também na maioria das residências, a introdução de produtos eletrodomésticos como fogão, geladeira, televisão e telefone.

Outro ponto que merece aqui ser discutido, refere-se às interferências do turismo no modo de vida da população receptora. Assim, percebe-se que este tipo de atividade gerou um processo de aculturação, ou seja, novos valores culturais introduzidos e assimilados pelos moradores, principalmente pelos mais jovens.

Esse fato leva o jovem ao distanciamento das práticas tradicionais, como a pesca artesanal, a produção de beiju etc. Na temporada de verão, período em que o turismo é 
mais desenvolvido, observa-se aumento da criminalidade, com ocorrências de furtos na Vila.

Em suma, com o incremento do turismo, notam-se as seguintes modificações na Vila de Itaúnas: valorização imobiliária, substituição do uso do solo de residencial por comercial, pressão sobre o sítio urbano da Vila que se expande em direção à rodovia ES10, que liga Itaúnas à sede municipal Conceição da Barra, aumento do número de famílias locais sem moradia.

Além dos fatores citados acima, também foi possível observar o adensamento urbano, aumento da demanda do abastecimento de água e saneamento, excesso de veículos no período de verão, visitação massiva aos microambientes frágeis do Parque, excesso de resíduos sólidos gerados pelos turistas e excesso com relação à capacidade de suporte, isto é, não respeito ao número máximo de visitantes por período de tempo que uma determinada área pode suportar, sem que ocorram alterações nos meios natural e cultural.

Uma questão importante evidenciada em campo, refere-se às especulações sobre a possível pavimentação da estrada de terra que liga Itaúnas a Conceição da Barra. $\mathrm{Na}$ visão dos moradores, as opiniões divergem com relação à benfeitoria que a estrada trará para a Vila e para o turismo, havendo tanto opiniões favoráveis como desfavoráveis.

Em suma, mesmo diante de todas as interferências geradas pelo turismo, este atualmente constitui um dos importantes elementos que compõem o panorama das relações econômicas e sociais do local. $\mathrm{Na}$ visão dos moradores nativos, o turismo como atividade econômica, é capaz de facilitar a entrada de dinheiro na micro-economia local, gerando renda e empregos para a população residente.

Nesse sentido, para continuar desenvolvendo a atividade do turismo em Itaúnas, concorda-se com as idéias de Rezende (2004), quando afirma que o mais prudente, mesmo diante de algumas dificuldades, é tentar buscar o turismo sustentável. Por meio do planejamento detalhado, do gerenciamento adequado de maneira estruturada e com adequada visão sistêmica, visando dessa forma diminuir as interferências negativas e potencializar os benefícios da atividade. Um dos motivos apontados pela autora para realizar o planejamento é a necessidade de adequação entre fluxo turístico e o núcleo 
receptor, o que significa atender as expectativas do primeiro sem esquecer os direitos do segundo no que se refere aos aspectos urbanísticos, ecológicos e sociais.

Segundo Rezende (2004) e Ignarra (200), para desenvolver a atividade do turismo dentro da proposta de um turismo ecológico e socialmente justo, existem definições e recomendações que orientam as políticas de implantação dessa modalidade. De acordo com as autoras o ecoturismo é uma modalidade de turismo que visa a preservação do meio e o bem-estar da população local.

Definido pela OMT (2003), o ecoturismo constitui-se numa forma de turismo baseada na natureza, com grande ênfase na conservação do meio ambiente, incluindo a diversidade biológica, os sistemas de vida selvagem e ecológicos, ressaltando a importância da educação do turista quanto ao ambiente ao modo de conserva-lo. As áreas de ecoturismo incluem comunidades humana, especialmente de povos tradicionais dessa forma, o plano de ecoturismo precisa estudar as maneiras de conservar as tradições e as identidades locais e o modo de levar benefícios a estas comunidades.

Entre as sugestões da OMT(2003), para o planejamento do ecoturismo estão, o estabelecimentos de padrões de capacidade de carga; medidas rigorosas de conservação da área natural; desenvolvimento de um centro de recepção ao visitante, com exposição sobre o local e sobre as técnicas de conservação; disponibilizar guias bem treinados, que possam oferecer informações exatas ao turistas; integrar as comunidades locais a atividade turística melhorando as condições de vida dessas.

Pautando-se nas sugestões explicitadas acima propostas por Rezende (2004), OMT (2003), e Ignarra (2000), seria interessante desenvolver o ecoturismo em Itaúnas tomando-se como base: a valorização das características culturais da região como o Ticumbi, Jongo, pesca artesanal, as casas de farinha; a criação de um núcleo direcionado ao planejamento do turismo; estímulo ao desenvolvimento de pesquisas que tratem da questão do turismo; uso sustentado dos recursos; formas alternativas de renda e sobrevivência para a população local e a necessidade da participação democrática na gestão territorial. 


\subsection{Estratégias adaptativas}

A fragmentação do território consubstanciada pelo uso, apropriação e exploração da terra na região de Itaúnas, gerou interferências no modo de vida da população residente da Vila, principalmente no que se refere às atividades de subsistência, relações de parentesco e territorialidade.

No novo cenário, os moradores vivenciaram a perda do espaço para a manutenção de seu modo de vida. Face a esse fator limitante, passaram a adotar certas estratégias como ajustes para se adaptarem à nova realidade imposta. Segundo Morán (1994), os diversos níveis de ajustamento, tais como: reguladores, de aclimação, desenvolvimento e os culturais e sociais têm por fim aumentar a adaptabilidade

Diante deste contexto, busca-se aqui compreender a adaptabilidade dos moradores frente aos desafios, imposições, carências, dificuldades, perigos e acasos exteriores ocorridos.

Morin (1989), nos adverte que para os estudos de adaptação se tornarem mais relevantes, faz-se necessário analisar a flexibilidade e plasticidade organizacionais da vida. Assim, neste trabalho, o enfoque será dado à questão da adaptabilidade, já que seu estudo, enfatiza a plasticidade das respostas humanas ao ambiente.

Em Itaúnas, percebe-se que os moradores nativos desenvolveram ajustes flexíveis, através do mecanismo de respostas a problemas percebidos. Assim, os indivíduos passaram a modificar seu comportamento em relação às atividades de subsistếncia, relações de parentesco e territorialidade, com a finalidade de alterar certas condições, presentes, melhorar as existentes e lidar com os problemas ambientais e(ou) com estressores.

Conforme já citado anteriormente neste trabalho, na década de 70, dois fenômenos que podem ser considerados estressores, estavam acontecendo simultaneamente em Itaúnas. A mudança gradual dos moradores da antiga Vila para a nova Vila, por causa da invasão das dunas e o início do processo de expropriação das terras causadas pela implantação da monocultura do eucalipto, que num primeiro momento ofereceu empregos, mas com o processo de mecanização, acabou desempregando muitas pessoas. 
As mudanças ocorridas no território, contribuíram para que muitos moradores migrassem para outras localidades em busca de empregos e os que ali permaneceram continuavam a viver de práticas extrativistas do mar e da terra, da pequena agricultura e da produção de farinha.

No entanto, no final da década de 70 e início da década de 80, a pacata Vila de Itaúnas que continha aproximadamente 20 casas e 2 botecos, feitos de taipa-de-mão e chão de barro, pertencente um ao Sr. Antero e outro ao Sr. Manoel Nogueira, passou a ser visitada por estudantes universitários.

Segundo o relato de um morador forasteiro, nessa época, Itaúnas não apresentava nenhuma estrutura para atender tais pessoas que vinham de outros lugares, não havia energia elétrica e apenas uma cacimba abastecia a Vila. No entanto, os moradores eram bastantes cordiais e abriam a porta de suas casas para abrigar as pessoas visitantes. Quando o local começou a ser procurado pelos visitantes, os moradores ainda não viam nestes a oportunidade de ganhar dinheiro.

A pouca estrutura para atender as pessoas que iam conhecer Itaúnas, foi aos poucos sendo introduzida por pessoas de fora, advindas de outras regiões do país. Diante desse fato, percebendo a possibilidade de obter algum dinheiro, os nativos, como se auto denominam, que já hospedavam os visitantes, passaram a cobrar pela estadia e alimentação.

O primeiro estabelecimento comercial pertencia ao Sr. Manoel Nogueira e sua esposa D. Lucy, os quais passaram a alugar pequenos quartos da casa e também a oferecer refeições composta de arroz, feijão, farinha e peixe, feitos em fogão de lenha.

A procura por Itaúnas, com o passar dos anos, foi gradualmente aumentando, dessa forma, as atividades tradicionais de subsistência foram sendo complementadas com trabalhos advindos do turismo.

A partir da década de 90, principalmente após o ano de 1996, o turismo passa a ser desenvolvido em grande escala. Assim, as interferências na configuração espacial e no modo de vida da população local se acentuam. Percebe-se que houve um processo de desenvolvimento da atividade turística, passando de pequena escala e gradualmente 
atingindo seu ponto máximo, entre os anos de 1998 a 2002. No ano de 2001, o número de pousadas chega a 45 .

O relato a seguir é de extrema importância para este trabalho, pois o morador explica o processo de introdução de novas atividades de subsistência, desde a produção de farinha até a exploração mercantilista do turismo:

"O negócio de lutar com farinha, esse negócio de roça, deu problema porque quando o pessoal mudou para cá (se refere a vila nova), já começou outro destino. Uns vendiam o terreno, foram vendendo para as firmas... $e$ as firmas foram comprando e desmatando. Então, depois que todo mundo mudou para cá, que faleceu a Cesita, uma firma, que muita gente empregou. A firma deu muito dinheiro e outros pescava no mar conforme já era, outros com outros serviço. Ai foram trabalhando de pedreiro e foi indo assim. Os terrenos aqui não valia nada a gente comprava os terrenos depois vendia por cem cruzeiro. Ai foi passando por ser ponto de turismo o negócio foi melhorando. Ai o turismo já foi entrando o pessoal que já tinha seus jeitozinho foi fazendo suas pousadas, seus restaurantezinhos, e por ai foi crescendo, foi crescendo e hoje está do jeito que tá, todo mundo já tá esperto no dinheirão, nos feriados a turma vem para poder soltar a grana.

O senhor acha que melhorou com o turismo?

Numa parte melhorou né? Porque quando vem assim sempre largam um dinheiro para a turma. Tem vez que não da certo não, mas tem vez que dá, a gente sabe que dinheiro tá dificil em tudo quanto é canto. Então tem vez que vem e gasta, mas povo que gosta de gastar mesmo aqui é povo de São Paulo, Belo Horizonte" (morador nativo, 72 anos).

Face às transformações ocorridas, para se acomodarem aos problemas decorrentes das "perdas" do território e se adaptarem à nova realidade, os moradores passaram a procurar estratégias para sobreviver nesse novo cenário. Desse modo, os moradores passam a adotar certos comportamentos para se ajustarem a certas condições impostas pelo ambiente natural e cultural, melhorar as existentes e lidar com os estressores. 
Um exemplo de um tipo de ajuste que os moradores tiveram quanto em relação à adaptabilidade ao tipo de turismo que é desenvolvido no local, o qual pode ser definido como sazonal, ou seja, aquele que se desenvolve apenas em épocas específicas do ano.

Em Itaúnas, os moradores se adaptaram a esse tipo de turismo e assim passaram a viver ciclicamente, de acordo com os diferentes períodos do ano, os quais são divididos e estabelecidos por eles em dois, o tempo marcado pela economia quase de subsistência e o tempo mercantil.

O período quando se ganha dinheiro, é chamado pelos moradores de "verão", que se estende desde janeiro até o Carnaval e também a "temporada de julho", que dura aproximadamente 15 dias. O "verão" é um período muito esperado pelos moradores e percebido como aquele em que se pode ganhar dinheiro. $\mathrm{O}$ outro período, chamado por eles de "inverno", se refere ao período quando não há mais movimento turístico na Vila.

Percebe-se que a divisão que fazem do tempo, é um modo de construção social do tempo, onde este é regido pela possibilidade de obtenção de dinheiro. É um tempo social construído por relações produtivistas e mercantilistas. $\mathrm{O}$ tempo para eles, tem a dimensão do produzir-se social e economicamente e não relação com as estações climáticas do ano.

Por meio do trabalho de campo, foi possível observar as mudanças que ocorrem em Itaúnas e no comportamento dos moradores em relação a essa divisão do tempo. De uma dia para o outro, com a chegada dos turistas, a Vila deixa de ser pacata, os moradores deixam de realizar suas tarefas habituais e passam a trabalhar em alguma atividade ligada ao turismo. A Vila se torna mais agitada com a chegada dos turistas. As relações sociais neste momento são mediadas pelo ritmo do trabalho remunerado e associadas ao turismo e o cenário se transforma.

Com o fim da temporada, os moradores voltam às suas outras atividades. Dessa forma, passam a pescar com mais intensidade no rio, as mulheres voltam ao rio quase que diariamente, para lavar roupa, limpar os peixes, as crianças voltam a brincar nas ruas da Vila, cenas que não são vistas quando os turistas estão no local. Observa-se então em Itaúnas, dois tempos, o natural e o mercantilista. 
Em Itaúnas, a imagem do pescador(a), no rio com sua canoa e seu remo, dá a idéia do tempo, ou seja, do ritmo da vida dos moradores em período fora da temporada. Do tempo visto como sinônimo de calma, de um tempo social construído por relações não produtivistas, que marcam o tempo da conversa, do relacionamento com o outro.

Na percepção dos moradores, o turismo significa geração de emprego e alternativa de trabalho e consequentemente oportunidade de obtenção de dinheiro. Como mostra o relato de dois sujeitos colaboradores da pesquisa:

"Meus pais hoje, moram no Braço do Rio. Moravam aqui, são todos daqui também. Eles foram embora, porque aconteceu assim que, passou um tempo, entrou uma fase ruim de serviço, ficou muito difícil, né? Aí eles foram morar para lá. É que não tinha turismo aqui em Itaúnas ainda. Então... foi antes de começar o turismo aqui em Itaúnas" (moradora nativa, 31 anos).

"Tem muita gente que trabalha ai no turismo. Daqui de dentro mesmo, tem muita gente que trabalha e deu serviço para esse povo. Hoje a Márcia tem a pousada dela ali, tem a Pousada Tartaruga, a Irerê, a Vila Tânia, do Jabá. Então abriu muito espaço para as pessoas trabalhar. Pessoas trabalham ai dentro, então isso melhorou um pouco a vida. Isso tudo deu muito trabalho para esse povo daqui" (morador nativo, 83 anos).

No cenário atual, a pesca artesanal marítima e na área do alagado, ainda é um̉a atividade representativa em Itaúnas, principalmente em termos de garantir a sobrevivência da família. No entanto, essa prática coexiste com as atividades ligadas ao turismo, as quais são sazonais.

Os modelos de subsistência verificados atualmente, não estão mais ancorados unicamente nas atividades tradicionais. Como estratégia adaptativa, os moradores passam ao exercício de múltiplas atividades, através das opções de trabalho oferecidas pelo turismo. Assim modificam as relações de trabalho e as estratégias profissionais tradicionais passam a dar lugar às estratégias empresariais e mercantilistas. 
Percebe-se no caso de Itaúnas, que o núcleo cultural, considerado como a subsistência do grupo, incluindo sua economia e tecnologia básica, de certa forma acabou influenciando a organização social e cultural da população humana de Itaúnas. As atividades de forrageio desenvolvidas atualmente em menor escala, agora se complementam com aquelas relacionadas ao turismo. Esse fato acarretou em interferências tanto na percepção e uso que fazem do território, como nas relações sociais e econômicas.

$\mathrm{O}$ termo forrageio, refere-se a atividades de subsistência que dependem de recursos alimentares não cultivados para formar a parte principal do suprimento alimentar. Usualmente isto implica numa combinação de coleta de plantas não cultivadas còm atividades de pesca ou de caça de animais selvagens (Kormondy \& Brown, 2002).

As atividades relacionadas aos serviços que o turismo acabou proporcionando, passam a representar não apenas uma saída econômica para a crise, mas também uma alternativa de vida. Neste contexto, evidencia-se também a produção individual de renda e manutenção do caráter unitário da economia doméstica. Assim, o salário advindo do turismo permanece sob o controle de quem trabalha e passa a ser o símbolo de sua autonomia.

Os serviços gerados pelo turismo se referem às seguintes atividades: cozinheiro, garçon, faxineiro, pedreiro, jardineiro, caseiro etc. Existem também aqueles moradores que utilizam de suas práticas tradicionais nas estratégias produtivas do turismo. Assim, as atividades de guia turístico, realizando passeios de canoas, cavalos, e o artesanato para a venda local, constituem-se em elementos da identidade cultural da população de Itaúnas que são utilizados na obtenção de dinheiro:

"Faz tempo que eu trabalho com negócio do turismo, sou canoeiro, guia. Sou guia da "Casinha de Aventura". E também faço meus trabalhos de artesanato. Faço arandela, luminária, abajur. Pois é, a gente trabalha com essas coisinhas. Eu sempre vendo no 'verão'. Agora neste que passou quase que não deu nada não. As vezes chega gente fora do verão e compra, mas é mais dificil. Eu trabalho com material com o talo do côco do buriri, aquele que mostra o cacho. Pode fazer o trabalho $e$ 
largar ali toda vida que não da broca, não da nada. Então, não carece botar no sol. Ele já vem de lá da praia e quando é de madeira eu faço pia, gamelão, faço pilão. Tem trabalho meu que já tá divulgado até em São Paulo por causa de um retratista que tirou minha foto aqui, eu, minha companheira, meus trabalhos" (morador de Itaúnas, 72 anos).

Semelhante ao que ocorre em Itaúnas, Garrote (2004), também observou que no Saco do Mamanguá-RJ, a população humana como estratégia adaptativa utiliza-se de atividades tradicionais, como no caso do artesanato, para se as adaptar à nova realidade do local, em virtude da atividade do turismo. Assim, os moradores utilizam-se da caixeta Tabebuia cassinoides, uma madeira leve e fácil de manusear, para a fabricação de peças para serem vendidas; outros utilizam taquara e cipó na fabricação de balaios.

Em Itaúnas, outra forma encontrada pelos moradores nativos para obtenção de dinheiro consiste no aluguel de suas casas para turistas, passando a coabitar temporariamente em casas de parentes bem próximos e que geralmente se localizam no mesmo terreno.

Constata-se em Itaúnas, uma adaptabilidade quanto às atividades de subsistência não tradicionais e desenvolvimento de habilidades e à capacidade de realizar uma diversidade de práticas não tradicionais, podendo-se notar a plasticidade comportamental dos indivíduos.

Discutindo as estratégias adaptativas dentro do universo sócioeconômico e estabelecendo uma relação destas com o núcleo familiar, pode-se afirmar que em Itaúnas, os moradores apresentam grande plasticidade. Muitos ajustes se realizam no agregado familiar, com a finalidade de maximizar a renda, assegurando dessa forma a manutenção da família. Esses ajustes, podem se fundamentar na combinação de diversas atividades desenvolvidas por eles, sendo viabilizadas por meio da formação de uma rede de relações sociais que geralmente não se limita à família nuclear.

Desse modo, as relações de parentesco em Itaúnas são importantes tanto para a manutenção da rede social que os une, como para o desenvolvimento das atividades de subsistência. Nas atividades ligadas à pesca artesanal, como também ao turismo, o núcleo 
familiar se torna muito importante na divisão das tarefas e no aumento da renda para a família.

Nas atividades relacionadas ao turismo, percebe-se a plasticidade comportamental dos moradores para se adaptarem às novas atividades e maximizar a renda. Assim, os arranjos adaptativos quanto ao modo de produção dos moradores são feitos de acordo com os laços de parentesco ou mesmo afinidade entre os membros da sociedade. Uma vez que os próprios parentes são empregados nos estabelecimentos comerciais. Da mesma forma, esse fato também pode ser observado nas atividades de pesca.

Em Itaúnas, as embarcações que saem para o mar são compostas por três indivíduos, os quais geralmente são membros da mesma família, ou amigos bem: próximo. Os homens saem para o mar, "lá fora", como eles dizem para a pesca em alto mar e as mulheres são responsáveis por limpar os peixes. Desse modo, nota-se a forma como se estabelece a divisão do trabalho entre os gêneros.

Silvano (1997), analisando pequenas sociedades de pescadores artesanais afirma que estas são baseadas inteiramente no parentesco. Nessas sociedades, pode-se notar atos de nepotismo ou de reciprocidade relacionados à subsistência. Na pesca ao mar, é muito comum que a tripulação seja sempre composta por irmãos, pais e filhos. A relação que estabelecem inclui a pesca conjunta e a assistência à família de um irmão que esteja impossibilitado de pescar.

Em Itaúnas, os pescadores ainda apresentam tais características e arranjos adaptativos apontados por Silvano (1997), uma vez que os moradores mantém estreitas relações de amizade entre si, as quais fortalecem a solidariedade entre o grupo. Assim, a solidariedade ainda se faz presente nas relações sociais, podendo ser evidenciada na distribuição dos peixes. Estes quando em fartura, passam a ser divididos entre outros membros do grupo, geralmente distribuídos aos mais idosos ou para as mulheres.

Esse fato também foi observado por Silva (2004), em Canguaretama-RN. Segundo a autora a estreita relação entre os componentes da comunidade de pescadores fortalece os laços de solidariedade, o que os fazem sentir responsáveis pela alimentação dos componentes do grupo. Desse modo, os que realizam melhores pescarias retiram da 
produção a parte de consumo para a família e também para aqueles que estejam precisando de ajuda, geralmente os mais velhos.

A solidariedade é vista por Ferreira (2002), como um dos traços característicos de comunidades tradicionais. Para a autora, o mutirão também testemunha estas práticas de cooperação, pois neste tipo de atividade não existe remuneração, mas relação de solidariedade e compromisso moral em corresponder aos pedidos de auxílio por parte daqueles que ajudaram. Tais formas de solidariedade não se limitam à unidade familiar, mas também aos parentes e amigos próximos que habitam em localidades próximas.

Observou-se no entorno de Itaúnas, a existência de alguns povoados, chamados pelos moradores de roças. Dentre esses, os mais próximos geograficamente da Vila são o Angelin e a Aldeia. Nesses pequenos espaços de terra, se reproduzem social e culturalmente várias famílias de parentes próximos ou distantes, as quais vivem da pequena agricultura e da criação de animais, como porcos e galinhas e da pesca. Essas famílias estabelecem entre si e com os moradores de Itaúnas, relações de troca, pequena venda de produtos da terra, ajuda mútua e solidariedade.

Em campo, pode-se evidenciar que a solidariedade acontece também no momento do mutirão, realizado na casa de farinha da comunidade de Santa Clara, Angelin, de uso comunal. $\mathrm{O}$ mutirão acontece na época da fabricação da farinha de mandioca e do beiju. Assim, na casa de farinha, as mulheres, se agrupam por alguns dias, para aproveitar a safra da mandioca e dessa forma os momentos são marcados por muita conversa entre avós, mães, tias, netos e sobrinhos.

Nesse tipo de comportamento que ainda existe entre os membros do grupo, percebe-se uma interação social na qual todos os envolvidos são beneficiados, denominado por Kormondy \& Brown (2002) de comportamento cooperativo.

$\mathrm{O}$ outro povoado que também mantém relações estreitas e de cooperação com Itaúnas é chamado pelos nativos de Aldeia.

Segundo relatos dos moradores da Aldeia, os membros mais velhos do grupo fixaram residências nesse local, antes ainda da implantação do Parque, em virtude do soterramento da antiga Vila. Mais tarde, esse local foi herdado por eles, em linha agnática, ou seja, entre os que descendem de um mesmo tronco masculino; linhagem 
patrilinear. Hoje, embora esse local pertença ao Parque, os moradores não foram expropriados e continuam residindo em tal local.

$\mathrm{Na}$ visão dos moradores, o fato desse local ter pertencido aos pais e deles terem herdado, assegura a eles o direito de apropriar e continuar nesse local, reproduzindo-se social e culturalmente. Tal direito estabelecido por eles, através das relações de parentesco, foi fundamental para continuarem a permanecer no local, agora dentro dos limites do Parque.

Segundo Campos (2000), o acesso à terra de uso comum tem uma relação direta com a tradição, com o costume e com a memória. O costume é passado de geração para geração. Esse fato dá à comunidade a certeza de que o espaço que utiliza lhe pertence, não como uma propriedade privada nos moldes em que é concebida modernamente, mas como um direito de usufruto que o tempo e a tradição lhes proporcionaram.

O direito da terra que pertencia aos ancestrais, fortaleceram os moradores da Aldeia e após anos de conflitos com a Unidade de Conservação, foram beneficiados com energia elétrica e água tratada, o que de certa forma os tranqüilizaram com relação a continuarem a viver no local, mesmo sendo uma área destinada a conservação.

Os moradores desse local, embora se localizem muito próximos da Vila de Itaúnas, possuem uma identidade própria e também estabelecem relações com os moradores, através da troca e da solidariedade.

A manutenção desses povoados no tempo e no espaço, de certa forma, deve-se aos seguintes fatores: à herança do território, às relações entre os parentes "próximos" e "distantes" e aos casamentos, preferencialmente contraídos no interior dos conjuntos, os quais ampliam a rede de relações sociais, "costurando", mesmo que de forma tortuosa, o tecido social do grupo.

\subsection{A terra e o mar: territórios vividos e apropriados}

Segundo Little (2002), o estudo da territorialidade tem como ponto de partida uma abordagem que considera a conduta territorial como parte integral de todos os grupos humanos. Esse autor define conduta territorial como sendo o esforço coletivo de 
um grupo social para ocupar, usar, controlar e se identificar com uma parcela específica de seu ambiente biofísico, convertendo-a assim em seu território.

A análise da territorialidade nesta pesquisa tem como finalidade, fornecer subsídios para a compreensão da relação dos moradores de Itaúnas com seu território, ou seja, com seu espaço vivido.

Busca-se neste trabalho, entender a complexa relação entre os moradores e seu território no plano simbólico, ou seja, os vínculos afetivos que mantém com o território, o uso social que dão ao mesmo, bem como as formas de defesa nele. Partindo do pressuposto de que a territorialidade envolve a apropriação do espaço vivido. Espaços estes preenchidos de sentidos e significados sociais e individuais, para determinados sujeitos. Sujeitos esses que expressam territorialidades distintas.

Entendendo a territorialidade como um comportamento humano espacial, existe uma expressão de poder que não é nem instintiva e nem agressiva, apenas se constitui em uma estratégia para afetar, influenciar e controlar o uso social do espaço.

Em Itaúnas, devido às pressões externas exercidas pelas mudanças no sistema fundiário, realizadas tanto pela implantação da agroindústria, como pela Unidade de Conservação e do desenvolvimento do turismo, o território que antes era mantido sob a lógica do comunitário, passou a se consolidar através de outra lógica, da apropriação privada e do poder estatal.

Os moradores nativos, com o processo de expropriação de terras, consubstanciado pela sobreposição de territórios, perderam o território da floresta que utilizavam para suprir suas necessidades, para a monocultura do eucalipto e para as área de preservação. A história de "perdas" ainda se estende para a Vila Antiga que foi soterrada e também para o território da pesca, que frequentemente é invadido, em virtude da pesca industrial predatória do arrasto.

Face a esse contexto, percebe-se que territorialidades distintas concretizam-se através do uso empresarial, governamental e comercial. O que vem propiciando novas formas de relação dos moradores com o ambiente que os cercam.

Entre os moradores de Itaúnas, a territorialidade se expressa de várias formas, um exemplo disso pode ser percebido no conflito gerado com a implantação da Unidade de 
Conservação. Esta seguindo o modelo norte-americano, aquele que entende que a ocupação humana se torna incompatível com os objetivos de conservação. Muitos moradores foram expropriados de suas terras e outros sofreram por um longo período de tempo, ameaças de expulsão de seus territórios, trazendo para suas vidas muita intranqüilidade.

No entanto, alguns moradores resistiram à pressão e alguns deles até hoje se encontram em suas terras. As histórias dessas famílias são repletas de luta e resistência, para não sair de seus territórios. A luta pela permanência no lugar, é um traço da identidade territorial, ou seja, da identificação que o grupo social desenvolve com seu espaço vivido e o direito de posse que lhes é transmitido de geração-em geração.

$\mathrm{Na}$ fala de uma moradora pode-se perceber a luta e resistência para que pudessem permanecer no lugar:

"Houve muita pressão para que a gente saisse desse lugar. Só não saímos porque resistimos à pressão que fizeram. Não deixamos que ninguém tirasse a gente daqui. Essa terra foi do pai do meu marido como é que a gente agora tem que sair dela" (moradora de Itaúnas, 52 anos).

Outro fator que faz emergir territorialidades inéditas é a indústria do turismo. Segundo Rodrigues (1996), esta atividade é responsável por produzir espaços delimitados e espacialmente destinados ao consumo da natureza. Esse consumo acaba valorando as paisagem, sejam elas, o mar, a floresta tropical, os Alpes ou os Andes. No entanto tais paisagens não se encontram em qualquer lugar, mas sim em determinados territórios. Territórios estes que passam a ser apropriados para tal atividade e onde se materializam outras mercadorias, ou seja, toda a infra-estrutura necessária para acomodar os turistas. Nesse sentido, são várias as formas pelas quais se produz rapidamente o novo espaço, que deverá proporcionar o descanso ou o consumo da natureza diferenciada ou, se preferirmos, das especificidades do território. Nesse processo, as amenidades de natureza mercantilizada, num primeiro momento como "pura" e isolada, passam a ser paulatinamente transformadas com a (re)produção socioespacial. 
Para Rodrigues (1996), a atividade do turismo passa a alterar não só a paisagem física, como as relações sociais e as relações de trabalho dos moradores, que passam a gravitar em torno da indústria do turismo e da prestação de serviços. Todo esse processo acaba afetando a relação que os indivíduos tem com o território. Nas palavras da autora "o espaço do/para o turismo constitui uma mercadoria complexa, pois ele mesmo é uma mercadoria" Rodrigues (1996, p. 56),

Em Itaúnas, percebe-se que a atividade do turismo causou forte especulação imobiliária, fato que acabou interferindo na maneira como os moradores, se relacionam com o espaço que habitam. Com a valorização das casas na Vila, os moradores passaram a alugar e a vendê-las com facilidade. As casas passaram a ter outro significado para os moradores, representando "moeda viva". Quando vendidas suas casas, os moradores vão geralmente morar em locais mais afastados da área central da Vila ou coabitam na casa de parentes. Esse fenômeno desencadeado pela especulação imobiliária em Itaúnas, também foi observado no Saco do Mamanguá-RJ. Segundo Garrote (2004), com a chegada do turismo àquele lugar, muitos moradores perderam suas terras - iludidos com a obtenção do dinheiro fácil, resultante de sua venda, principalmente para veranistas. Com a venda das casas, muitos migraram para outras cidades e os que ficaram foram morar em locais bem afastados e com pouco espaço.

Em Itaúnas, na temporada, percebe-se também a facilidade dos moradores se deslocarem de suas casas com agilidade, na intenção de alugar para os turistas, desenvolvendo um modo de vida itinerante. Esse fato pode ser considerado uma estratégia adaptativa que encontraram para obter dinheiro.

Neste contexto, o que se constatou com a presente pesquisa é que territorialidades inéditas emergem neste cenário, ou seja, o espaço vivido passa a ser visto pelos moradores, como mercadoria, fruto das interferências geradas pelo turismo e pela especulação imobiliária, onde impera a lógica do capitalismo.

Com o aumento de pessoas de fora, no período da temporada, há, muitas vezes, uma sensação de invasão do lugar, só recompensada e(ou) tolerada pelos benefícios financeiros oriundos da passagem do turista. Neste contexto, coexistem duas 
territorialidades antagônicas: trabalho e turismo. Enquanto a praia é território de lazer e descanso para o turista, para aquele que trabalha é território de labor e cansaço.

O turismo representa para os moradores, um meio alternativo de trabalho, no qual se obtém a renda. No entanto, com relação aos turistas, os moradores têm outra percepção. A cordialidade característica deles ainda se mantém, mas estabelecida atualmente sobre os parâmetros mercantis. Dessa forma, os turistas em grande fluxo, são sempre motivo de reclamação. São as contradições existentes, conforme pode-se notar no depoimento abaixo de uma moradora:

“Aqui em Haúnas, São Sebastião ficà feliz quando پem bastante gente para a procissão dele (evento que acontece todo ano nos mês de janeiro, mês de maior movimentação turística), mas quando tem muita bagunça ele fica zangado e manda todo mundo embora. Ai você vê aquele monte de carro indo embora, um atrás do outro" (moradora nativa, 46 anos).

Com a venda de seus imóveis, os moradores afastam-se da área mais central da Vila e passam a morar em locais mais distantes, como por exemplo no novo loteamento. Este constitui-se numa área comprada pela Prefeitura e loteada para a venda, dando prioridade para os moradores nativos.

$\mathrm{Na}$ área central, atualmente se localizam em maior proporção os estabelecimentos comerciais como pousadas, restaurantes e bares. São os novos territórios impostos pelo turismo. Antes esse espaço mais central era local onde residiam os moradores nativos. Hoje esses espaços são (re)apropriados pelo turismo, o que causa também uma fragmentação do território da Vila.

Ainda se referindo ao processo de deslocamento da população nativa para áreas mais afastadas, como no caso do novo loteamento, pode-se afirmar que esse fenômeno acaba afetando a relação de parentesco e algumas características do modo de vida dos moradores.

No depoimento de uma moradora, percebe-se elementos em sua fala que indicam as interferências causadas no modo de vida: 
"Nossa a gente sentiu foi muita falta, com a mudança deles para o loteamento (referindo-se aos vizinhos da frente). Então, a gente conversava de dentro de casa, não precisava nem atravessar a rua. Quando uma precisava de ajuda a outra logo fazia. Quem morava ai era D. Aninha, prima do meu marido, irmã de criação, foi criada pela familia dele. Agora que ela mudou lá (referindo-se ao loteamento), ficou muito ruim, ela também reclama muito, porque as plantas dela ficaram tudo aqui, ela é benzedeira" (moradora nativa, 67 anos).

Outro fenômeno que está acontecendo na Vila e que está associado a elementos da territorialidade, refere-se à venda dos novos lotes adquiridos pelos nativos que compraram por 500 reais e agora estão revendendo por 6.000 reais. Isso comprova mais uma vez que eles estão percebendo o território como mercadoria. Uma vez que o território passou a ser mercantilizado em função do turismo.

Um outro indício de territorialidade se expressa na separação que os moradores nativos fazem entre os nativos e pessoas de fora, chamados por eles de "forasteiros". Esse fato indica um certo tipo de defesa do território, já que este, na visão dos moradores, em grande parte lhes foi tomado.

Através dos exemplos práticos, pode-se perceber que com a introdução de novas formas de apropriação do território, tanto estatal, como particular e por empresas privadas, a populações humanas envolvidas neste processo passam a criar novas e distintas territorialidades; ou seja, novas formas de concepção de uso e- de domínio e apropriação do território, que estão ligados às suas atuais necessidades de adaptação.

Em Itaúnas, a análise da territorialidade também se estende ao território marinho, uma vez que este é apropriado pelos pescadores artesanais, em sua atividade de subsistência.

$\mathrm{Na}$ apropriação do mar, os pescadores constróem sistemas de posse do território marinho, através dos quais são definidas as formas de acesso aos recursos pesqueiros. Essa organização social do território, se estabelece por meio de regras instituídas entre os membros do grupo. 
Evidenciou-se em Itaúnas, que os pescadores possuem um vasto conhecimento do território marinho e das zonas do mar, locais onde há concentração de peixes, ou seja, os pesqueiros. Para se localizarem no mar, utilizam-se de alguns pontos que se encontram fixados no solo da Vila, servindo-lhes como referência. Além do conhecimento do território marinho, possuem saberes relativos às técnicas de pesca e do ciclo das marés o que garantem de certa forma a reprodução do grupo social.

A territorialidade marinha depende não somente do meio físico, mas de relações sociais estabelecidas entre os membros do grupo. $\mathrm{O}$ acesso que os pescadores de Itaúnas têm ao território marinho se estabelece de forma comunitária, ou seja, todas as tripulações têm acesso livre aos territórios marinhos e na busca pelos peixes.

No entanto, a prática da pesca artesanal em Itaúnas vem, ao longo dos últimos anos, sofrendo ameaças, devido à invasão do território marinho pelas embarcações que realizam a pesca de arrasto.

Os barcos de arrasto, vistos bem próximos da praia de Itaúnas, principalmente na época de verão, são bem maiores do que a maioria das embarcações dos demais pescadores artesanais, além disso utilizam redes de porta. $\mathrm{O}$ arrasto de porta segundo Silvano (2004), consiste em duas redes emparelhadas que terminam em um saco, arrastadas junto ao fundo com o auxílio de pesadas estruturas de madeira (as portas).

A pesca predatória de arrasto que dedica-se quase que exclusivamente à pesca de camarão acaba arrastando também filhotes de peixe, plâncton e tartarugas, interferindo na cadeia alimentar. Dessa forma, acarreta um desequilíbrio ecológico no ecossistema marinho. Além de ser responsável pela redução do estoque pesqueiro, destrói equipamentos de pesca dos pescadores artesanais.

Situação semelhante ao impacto da pesca de arrasto acontece no Saco de Mamanguá-RJ. Diegues \& Nogara (1994), afirmam que esse tipo de pesca vem sendo realizada no interior do local, onde há abundância de camarão, causando grande impacto na complexa e rica cadeia trófica e também, a escassez de camarão.

Muitos pescadores de Itaúnas afirmam que houve uma redução na quantidade de peixes no mar e atribuem o fato ao problema da invasão do território de pesca, efetuada pela pesca predatória. 
No cenário da pesca em Itaúnas, percebe-se a existência de dois grupos distintos que realizam a pesca em um mesmo território marinho; porém um desses traz consigo uma tecnologia mais avançada. Dessa forma, acaba suprimindo a condição de existência do outro grupo, o dos pescadores artesanais.

Para os pescadores artesanais de Itaúnas o mar não representa somente um meio físico, mas resultante de um processo de práticas culturais, onde os membros da comunidade se reproduzem material e simbolicamente.

Dessa forma, concorda-se com as palavras de Ferreira (2002), quando esta afirma que o território deve ser visto na perspectiva não apenas de um domínio ou controle politicamente estruturado, mas também de uma apropriação que incorpora-uma dimensão simbólica.

Por meio da análise da territorialidade, percebe-se que apesar das perdas sofridas dos territórios da floresta e do mar, os moradores ainda possuem um vasto conhecimento do seu território, pois ainda mantém certa dependência para com esses, os quais ainda fornecem os meios de subsistência, os meios de trabalho e a reprodução social do grupo.

A identidade territorial é fortemente percebida em Itaúnas, não apenas pelo reconhecimento do mesmo como fonte dos recursos para a subsistência, como pela consciência expressa pelos moradores, da beleza do local, quando afirmam não existir lugar mais belo e melhor para viver:

"Mesmo tudo mudando, eu gosto daqui. Certo tempó eu fui morar lá no Braço do Rio também onde minha mãe mora. Morei lá nove anos, ai depois mudei de volta, senti muita falta desse lugar, da tranqüilidade, do sossego. Gosto muito daqui e acho que não saio mais daqui" (moradora nativa, 31 anos).

"A gente gosta muito daqui, não tem lugar melhor para nós do que aqui. Vários lugares a gente vai, Pedro Canário, Conceição da Barra, Braço do Rio, São Mateus, Linhares, todo esses canto aí a gente nunca moremos. $E^{\prime}$ só aqui mesmo. O povo gosta demais daqui, tem gente aí que no dia em que vão embora, de São Paulo de Belo Horizonte, ainda vão com pena. É bom aqui porque é o 
lugar que não tem violência, pessoa anda ainda a noite inteira, é menina, é mulher" (morador nativo, 52 anos).

"Eu adoro Itaśnas, nasci aqui, cresci. Ali tem um loteamento e eu quero ver se compro meio lote. Aqui é calmo não tem violência. Essa rua é uma beleza. Aqui em Itaúnas... a gente vai se acostumando com a nova Itaúnas. Aqui é um lugar sossegado, tem mais espaço para a pessoa viver, pescar, a pessoa sai, $e$ as pessoas não mexem nas coisas" (morador nativo, 50 anos).

Para concluir esse tópico, é preciso fazer a ressalva de que os moradores desenvolveram vários ajustes para se adaptarem aos novos territórios impostos. Porém, isso não significa que não sejam necessárias ações (projetos) para melhorar as condições de vida dessa população, a qual carece de empregos.

"A gente aqui não tem dinheiro, porque não tem trabalho, fora de temporada o povo vive do que a terra oferece, $o$ que se planta é o que se come" (moradora de Itaúnas, 23 anos).

\subsection{Elementos da tradição e simbolismo: pesca, extrativismo, festas e rituais}

Nos trabalhos de Diegues (2002 e 1993), Ferreira (2002) e Little (2002), existem algumas definições acerca de população e cultura tradicionais. No entanto, assume-se neste trabalho que atualmente não existe uma população típica e totalmente tradicional enquadrada num conceito fechado. $\mathrm{O}$ que existem são populações que por causa de algumas características que apresentam, relacionadas a forma de reprodução material, social e cultural, são denominadas de tradicionais.

Entre essas populações chamadas de tradicionais, que se encontram espalhadas pelo imenso território brasileiro, existem muitas diferenças, as quais são justificadas pelas divergências do meio em que cada uma habita, o sistema de produção, bem como o modo de vida. Estas diferenças ainda dependem também do grau de interação com grupos urbano-industriais. 
O que se vê atualmente, é que as populações tradicionais são dinâmicas, isto é, estão em constante mudança, seja pela sintonia com as transformações que ocorrem no local e principalmente com as que chegam até elas; ou seja, por fatores endógenos ou exógenos.

Verificou-se em Itaúnas, que mesmo com o processo de sobreposição no uso do território, onde grandes extensões de terra anteriormente integradas ao sistema de posse comunal deram lugar à propriedade privada e estatal, algumas práticas tradicionais continuam se desenvolvendo. Como por exemplo no caso da pesca artesanal, tanto no mar como no rio e na área de alagado, das manifestações culturais, como o Ticumbi e o Jongo, da produção comunal de farinha, das relações de parentesco, de compadrio e da troca.

Tais práticas tradicionais fazem parte da identidade cultural dos moradores de Itaúnas e podem ser encontradas até hoje, constituindo-se como base da organização social.

Segundo Silva (2003), a cultura pode ser definida dentro de diferentes concepções, resultantes de diversas perspectivas analíticas. No sentido antropológico, entende-se cultura como comportamento social de um grupo, onde engloba-se um conjunto de códigos e convenções simbólicas.

No caso da cultura popular, Silva (2003), afirma que esta se constitui numa expressão de um universo simbólico que como tal revela uma visão de mundo: valores, padrões, crenças e costumes.

Entendendo então a cultura como um sistema articulado de símbolos e significados emergentes do cotidiano da vida de um grupo, ela se torna um referencial de identidade do grupo. Neste sentido, as manifestações culturais, como expressão simbólica de um coletivo, passam a representar uma dimensão da sua vida que, transmitindo-se através dos tempos, vai constituindo e reconstituindo a sua história (Silva, 2003).

Em Itaúnas observou-se que muitos moradores realizam a pesca marítima, no rio e alagado. Essas práticas culturais são marcadas pela simplicidade da tecnologia utilizada e pelo baixo custo da produção. Diante dessas características, pode-se afirmar que em Itaúnas, os pescadores ainda realizam a pesca artesanal. 
Quanto à pesca marítima, esta é realizada apenas pelos homens, os quais saem para o "mar de fora" em canoas a remo. A pesca realizada com linha, é praticada principalmente na captura do Peroá, e quando utilizam redes de malha larga estão na captura de outros tipos de peixes maiores, como por exemplo o Cação.

No rio e alagados, a pesca é realizada tanto pelos homens, quanto pelas mulheres, os quais utilizam-se de redes de fio de nylon ou de varinhas para a captura do pescado.

Um outro elemento da tradição ainda presente em Itaúnas refere-se à prática do mutirão. A realização desse tipo de atividade, testemunha a cooperação e a solidariedade entre os moradores. Essa prática pode ser evidenciada na casa de farinha de uso comunal, no momento da fabricação da farinha de mandioca e do beiju. A casa de farinha encontra-se na comunidade de Santa Clara - Angelin.

Os equipamentos para o fabrico da farinha são construídos de modo artesanal. Constituem-se de um ralo, único equipamento elétrico no processo, um tacho aquecido à lenha e uma prensa esculpida em grandes toras de madeira.

No processo de fabricação de farinha, o aipim, depois de descascado, lavado e ralado, vai para a prensa, para liberar água, resultando em uma massa. Esta é mergulhada em tachos com água para tirar a goma, utilizada nos beijus. Retirada a goma, a massa é prensada para tirar o caldo e quando seca, é torrada nos fornos sobre os pratos de cobre para fazer a farinha. Além da produção de farinha, há também a produção de quitutes como beiju, farinha de coco e também o óleo de côco.

A produção de óleo de coco, consiste em uma prática que também se mantém viva entre os moradores de Itaúnas e exige certos conhecimentos dos procedimentos e o respeito às fases da lua, podendo ser considerada como um ritual de magia:

"Para fazer o óleo de côco é preciso possuir bastante conhecimento dos procedimentos e mais que isso, manter respeito no momento quando está se fazendo. É um tipo de ritual, só pode ser feito na fase de lua cheia, no dia de lua mesmo. Então, primeiro você rala o coco, depois você pega o caldo e deixa descansar para depois ferver bastante e mexer com uma colher de pau. Nesse momento você tem que ter muita concentração e não pode haver zuera de crianças por perto. Quando você não respeita, $o$ 
caldo desanda e de 10 litros que você prepara, você não consegue tirar um de óleo" (morador de Itaúnas, 21 anos).

Sendo a população de Itaúnas fruto de uma miscigenação entre índios, negros africanos e portugueses, algumas práticas culturais, herança de seus antepassados, ainda se fazem presentes e se concretizam nas manifestações folclóricas. Estas carregam fortes traços da cultura africana, heranças deixadas pelos negros africanos que se expressam através do Jongo, do Ticumbi ou Baile de Congo e da Capoeira.

Esse tipo de comportamento cultural, visto ainda hoje em Itaúnas, se encaixa dentre as camadas da cultura, na da supra-estrutura, a qual engloba as diversas modalidades de criatividade artística e lúdica, processos rituais cerimoniais, sistema de valores e modalidades de crença e conhecimentos ligados ao mundo real e imaginário.

As manifestações folclóricas chamadas pelos moradores de "brincadeiras", são realizadas nos dias de Festas em que se homenageiam os Santos, principalmente São Benedito, São Sebastião e Santa Clara.

A Festa de São Benedito e São Sebastião acontece nos dias 17, 18, 19 e 20 de janeiro, num clima de alegria e devoção.

Nos dias 17 e 18 acontecem os ensaios gerais dos grupos de Ticumbi. No entanto, o momento central da Festa acontece no dia 19, em comemoração ao dia do santo negro, São Benedito e no dia 20 o dia de São Sebastião, o santo branco. Nesses dois dias, acontecem a missa ou celebração, procissão, apresentação dos grupos folclóricos, refeições, queima de fogos e fincada do mastro.

Nos dois dias, 19 e 20, é o momento em que a comunidade de devotos se encontra mais próxima das divindades louvadas na Festa e diferentes instituições locais se relacionam mais intensamente, agregando também as outras comunidade próximas da Vila. A participação de todos reforça o espírito comunitário da população humana de Itaúnas.

De acordo com Passos (2002), as festas oscilam entre dois pólos: o da cerimônia, que é o rito propriamente dito e o da festividade que é o da efervescência cultural. Este mesmo autor ainda afirma que as festas acontecem numa explosão de vozes e ritmos, onde a população vivencia fatos concretos, temores, sonhos e crenças. 
Pode-se ainda afirmar, que a Festa não representa apenas um momento de expressão dos valores culturais, mas diversos tipos de fenômenos que aparecem integrados, conferindo-lhes o caráter de um fato social total, pois nela podemos encontrar aspectos religiosos, míticos e cosmológicos, bem como aspectos econômicos, políticos, institucionais e morais.

Nesses dias de festas, o largo da Igreja torna-se palco dessas brincadeiras folclóricas, descritas a seguir:

Jongo ou Jango: pode ser caracterizado como uma espécie de samba de roda. Dele participam homens, mulheres e crianças que dançam em roda numa movimentação de sentido anti-horário ao som de tambores, casacas - reco-reco de cabeça - e caixas. Esses instrumentos são, na maioria das vezes, fabricados de forma artesanal pelos próprios componentes do grupo. Entre os componentes dos grupos, existem homens e mulheres, havendo uma divisão entre estes, sendo as mulheres as dançarinas e os homens os tocadores.

Ticumbi ou Baile de Congo: essa manifestação folclórica é realizada por meio dos grupos de Baile de Congo, mais conhecidos como Ticumbi. São compostos por 15 ou 17 homens que brincam e os seus acompanhantes, geralmente os mais velhos, as mulheres e as crianças. Do grupo que brinca, um integrante do grupo é chamado de viola. $\mathrm{O}$ qual toca uma viola de 14 cordas. Dez ou doze deles são os congos ou corpo de baile. Tocam pandeiro, cantam e dançam, organizam-se aos pares em duas fileiras que ficam de frente para o viola. Essas duas fileiras, em determinados momentos da dança, fazem passos encostando os ombros, arrastando os pés, fazem roda entre outros movimentos específicos.

A brincadeira do Ticumbi constitui-se em uma dança dramatizada, transmitida de geração a geração, onde só é permitida em seu corpo de baile, a participação de homens. Segundo Neves (1978), o Ticumbi constitui-se em um cortejo real que se segue com uma embaixada de guerra e com episódios de combate.

O Ticumbi, tem o seu enredo, o seu assunto fio, que se desenvolve longamente na repetição de bailados, contos e embaixadas. No enredo do Ticumbi, dois reis, Bamba e Congo, disputam fazer cada qual sozinho, a festa de São Benedito. Há embaixadas de 
parte a parte com desafios atrevidos, servindo de embaixadores dois secretários. Por não ser possível qualquer entendimento ou ajuste entre os dois grupos guerreiros, trava-se uma guerra, tremenda luta bailada. Vencido, o rei Bamba submete-se junto com seus vassalos, ao batismo, termina-se o auto com a festa em honra ao rei Congo (Neves, 1978; Ferreira, 2002).

Quanto à vestimenta, os participantes do Ticumbi, vestem-se a caráter, de longas batas brancas com transpasse de fitas coloridas, as calças também são brancas. A cabeça é coberta com um lenço branco e um vistoso chapéu enfeitado com flores coloridas feitas de papel. Os reis trazem uma coroa de papelão feita de papel dourado e um peitoral com espelhinhos e flores, uma capa e uma espada. Os dois secretários se diferenciam dos Congos por vestirem capas (Neves, 1978).

Nota-se que a drạmatização do Ticumbi, é de fundo nitidamente africano e constitui uma remanescência ainda viva no norte capixaba. Percebe-se nessa manifestação, elementos que consubstanciam tanto o sincretismo religioso da brincadeira, como também apontam a resistência cultural que remota à épóca da escravidão dos negros africanos, que ali viveram e trabalharam.

De acordo com as idéias de Passos (2002), pode-se afirmar que a Festa de São Benedito e São Sebastião é um tipo de memória afetiva, construtora da identidade que continua se manifestando, pois a memória também continua viva. Ainda segundo Passos (2002): "as vozes do ontem são ouvidas alimentando as origens":

"O Ticumbi é do tempo do cativeiro, esse que nós brincamos, é bem mais representado porque ele já é um Ticumbi falado ha muitos anos. Então eles gostam mais de apreciar o Ticumbi velho, dos velhos, dos antigos. Dos cativeiros que tinham aqui, que é da época dos tios do meu pai, do finado Liberato, que era o pai de criação dele, esse é dessa época da Itaúnas velha" (morador de Itaúnas, 52 anos).

Atualmente existem três grupos de Ticumbi em Itaúnas: Ticumbi de Itaúnas, Ticumbi do Bongado e o Ticumbi do Angelin. Este último grupo foi criado em 2004, após um cisão do grupo do Ticumbi do Bongado, o mais antigo. A primeira vez que o 
grupo brincou foi durante a festa de Santa Clara realizada no dia 11 de agosto de 2004 no Angelin, distante $2 \mathrm{Km}$ da Vila de Itaúnas.

Quanto à capoeira, esta, segundo Silva (2003), continua a se enquadrar entre os principais elementos culturais do Brasil. Foi utilizada pelos escravos como forma de luta para conquista e defesa da liberdade.

Historicamente falando, o que motivou a capoeira foi a privação do homem a liberdade, determinado pelo regime escravocrata, ocorrido no Brasil entre os séculos XVI e XIX. Nesse período predominavam não só a falta de liberdade, mas também a insegurança de vida dos escravos. Sobreviver era resistir e resistir tornou-se uma estratégia onde o corpo se tornava o principal referencial.

Segundo discorre Silva (2003), a resistência não era apenas à violência física, mas também à ideologia, exercidas pelos dominadores, os quais impuseram aos negros novos valores culturais. Nesse contexto, a capoeira representou um elemento importante na preservação da identidade sociocultural do negro no Brasil.

Em Itaúnas, a capoeira se faz presente entre os mais jovens e crianças. No entanto, sofreu um processo de aculturação, com introdução de outros elementos.

Um outro elemento da identidade cultural de Itaúnas, refere-se ao forró, expressão musical e dança que faz parte da tradição local e que ainda se mantém, mas agora dentro de uma outra linguagem, devido às influências da mídia. Observou-se em Itaúnas, que o forró ainda é praticado e se tornou uma atração turística. Para os moradores locais, Itaúnas se tornou a "Capital Nacional do Forró".

Diante desse contexto, novos grupos de forró em Itaúnas foram formados por moradores nativos, esse fato ilustra que além dos moradores possuírem uma identidade cultural ligada ao forró, perceberam nesse a oportunidade de atrair turistas e consequentemente ganhar dinheiro.

Outro fato observado, é que mantêm-se também em Itaúnas, a arte de tecer cestarias, confecção de vasilhas de barro, miniaturas de canoas, bancos e mesas para decoração, esteiras, cestos e outros produtos ornamentais.

Os moradores de Itaúnas, por estarem circundados por um ambiente natural, 0 qual lhes fornece os meios de subsistência, os meios de trabalho e produção, estabelecem 
uma relação de dependência para com aquele, o que faz com que tenham uma maneira própria de representá-lo e classificá-lo. Uma vez que estão completamente integrados em seu ambiente, à sua maneira, estudam tudo aquilo que os interessam.

Assim, a forma de representação da natureza pela população local, se estabelece dentro de uma lógica diferente da de uma sociedade urbano-industrial, onde o ambiente natural foi quase totalmente substituído pelos ambientes construídos pelo homem. Para os moradores de Itaúnas, alguns fenômenos naturais e espécimes do reino animal e vegetal são classificados de acordo com sua importância nas atividades de subsistência.

Segundo Lévi-Strauss (1997), as sociedades pré-industriais nomeiam e conceituam as coisas da natureza, em função de suas necessidades. Ou seja, dão importância para aquilo que lhes é importante.

Observou-se entre os moradores, que estes possuem um vasto conhecimento sobre os componentes do ambiente biótico e abiótico dos ecossistemas presentes. Assim, conhecem os ciclos da natureza das marés, das fases da lua e dos ventos que predominam na região. Esse conhecimento se deve ao fato desses fenômenos da natureza, serem considerados importantes para os moradores, uma vez que interferem em suas atividades de subsistência.

A representação simbólica que fazem dos elementos que compõem o ambiente biótico e abiótico se estabelece de forma diversa da constatada no ambiente urbanoindustriais, são atribuídas personalidades a eles. Por exemplo, podem ser classificados como "bons" ou "maus".

Este é o caso dos ventos. De acordo com a classificação dos moradores, existem vários ventos e assim chamados por eles de, Leste, Nordeste, Terral, e o Sul. Este último, geralmente vem acompanhado de chuvas, frio, atingindo a dinâmica do mar, tornando-o agitado, impossibilitando os pescadores de saírem para o alto mar e alterando a dinâmica dos cardumes de peixes. Dessa forma os moradores classificam-no como mau:

"Quando o vento sul, vem ele traz coisa ruim, mas quando ele vai embora, ele leva tudo de ruim" (morador de Itaúnas, 23 anos). 
"Quando o vento Sul chega, ele perturba a gente, ninguém gosta dele. A cabeça da gente fica até rodando. Ele atrapalha a pesca, o mar fica ruim, ai não tem peixe" (moradora de Itaúnas, 46 anos).

Simão (2003), estudando a comunidade de Cachoeira do Guilherme, na Estação Ecológica Juréia-Itatins-SP, observou que o ventos exercem certa influência na queima de seus roçados. Dessa forma, os moradores consideram-no importante e passaram a classificá-los como "bons" e "ruins", diferenciando-os em sete tipo. Os ventos bons são: leste, noroeste, nordeste e sudoeste e os ruins para a queima são o sul, sudeste e norte.

Aos saberes e classificações do meio natural, Lévi-Strauss (1997), denomina de a "ciência do concreto" e afirma que esses saberes vêm sempre acompanhados por um repertório de palavras e conceitos para sua classificação.

$\mathrm{O}$ mesmo autor afirma que essa ciência do concreto existe em sociedades onde há relações de contato e dependência para com um ambiente natural. Assim, cria-se a necessidade dessas populações em classificar o mundo ao seu redor. Essas sociedades baseiam-se num conhecimento profundo e muito pormenorizado das características físicas das plantas, dos animais e dos fenômenos naturais.

\subsection{A questão do manejo e conservação do ambiente natural}

Na natureza existem os recursos ${ }^{4}$, os quais são imprescindíveis para a reprodução e sobrevivência dos organismos. No entanto, a população humana vem ao longo do tempo, criando sérios problemas ecológicos devido ao uso excessivo e predatório de tais recursos. Na discussão sobre uso e abuso dos recursos pelo homem, a tecnologia utilizada por este e o sistemas de manejo são pontos centrais.

Em Itaúnas, o uso e a apropriação do ambiente e dos recursos ao longo dos anos, foram se modificando. Na conjuntura atual, o ambiente e os recursos passaram a ser manejados não mais sob a ética do bem de uso comum, mas em função do uso estatal e privado, neste caso, transformados em florestas particulares das empresas madeireiras. 
Segundo Castro (2004), os sistemas de manejo existentes são baseados em regras que definem quem tem acesso a área manejada, quando e como um determinado recurso pode ser explorado. São formulados em geral, pelo governo com bases em informações ecológicas do recurso, não considerando em muitos casos, a dimensão humana. Este mesmo autor ainda assume que as variáveis sociais devem ser incorporadas no sistema de manejo, uma vez que estas influenciam de alguma forma o comportamento dos usuários com o recurso.

Em outras palavras, o manejo dos recursos naturais deve ser baseado nas características ecológicas e contextualizado dentro da realidade social, na qual os usuários se inserem. (Begossi et. al., 2004).

Em Itaúnas, a forma autoritária de implantação da monocultura de eucalipto e da implantação da Unidade de Conservação, acabou criando conflitos com a população local, principalmente no que se refere ao manejo e conservação do ambiente natural.

A maneira autoritária e não dialógica de implantação e consolidação do PEI, não possibilitou uma relação saudável com os moradores do local, o que causa até hoje alguns conflitos. Estes ocorrem em virtude das limitações quanto ao manejo natural efetuado pelos moradores, como no caso da extração de lenha, ervas medicinais, caça, criação de porcos.

Além de proibir as atividades tradicionais de subsistência, principalmente a caça, 0 parque não ofereceu alternativas de trabalho para a população local. Dessa forma, apesar das restrições locais, os moradores continuaram e continuam a realizar tais atividades. Isto ocorre inclusive, porque o PEI não dispõe de uma equipe que possa dar conta de fiscalizar toda a área do parque.

Garrote (2004), em seu trabalho, também registra que a população humana do Saco de Mamanguá-RJ, continua utilizando a caça como um constituinte na dieta alimentar. A autora ainda afirma que na utilização dos recursos, a população local não sofre impacto de uma fiscalização mais severa do órgão administrativo.

\footnotetext{
${ }^{4}$ Qualquer componente do ambiente que possa ser utilizado por um organismo, como por exemplo, alimento, solo, mata, minerais (Academia de Letras do Estado de São Paulo. Glossário de ecologia, 1987).
} 
No PEI, as atividades consideradas como as maiores ameaças incluem o desmatamento ou alteração da vegetação nativa, o fogo sobre vegetação nativa, a coleta seletiva de madeiras nativas, espécies ornamentais e frutíferas, a caça (abate) e a captura (cativeiro) de espécies animais, a coleta de frutos para alimentação e a extração de lenha.

Para que esse quadro de conflitos no manejo e conservação do ambiente natural de Itaúnas se reverta, faz-se necessário que a posição autoritária dos órgãos administrativos se modifique e que essa nova geração de cientistas do século XXI, inclua em suas gestões a dimensão humana, ou seja, que passem a enxergar o ser humano como parte do ambiente natural e dialoguem com seus saberes.

Faz-se necessário também o desenvolvimento de projetos participativos onde a população local se sinta engajada e responsável pela conservação do ambiente.

Outra questão refere-se a criação de programas de melhoria das condições de vida, por meio de atividades compatíveis com as especificidades socioeconômicas e ambientais, privilegiando-se aquelas alternativas ecológica e socialmente mais adequadas.

Repensar a situação de Itaúnas, significa abrir discussões para propor alternativas de manejo dos recursos pelas populações residentes na Unidade de Conservação. É fundamental que essas alternativas sejam condizentes com a vocação natural da região e ao mesmo tempo atendam às atuais necessidades da população humana. Isso, com base no conhecimento acumulado pela população em suas atividades tradicionais. 


\section{CONCLUSÕES}

Por meio da realização desta pesquisa, pode-se notar que na região de Itaúnas houve um processo de sobreposição do uso do território, que causou uma fragmentação do mesmo. A lógica de apropriação do território passou de comunal para diversos interesses, tanto de preservação como de uso e exploração, causando alguns conflitos de ordem ecológica, social, cultural e econômica.

No novo cenário imposto, com a ausência de espaço para obtenção de recursos necessários à sua sobrevivência, a população humana vê-se forçada a adicionar novas atividades de subsistência às antigas práticas culturais. Assim, como estratégia adaptativa, vem buscando inserir-se em novas atividades econômicas, principalmente aquelas ligadas ao turismo. Além desse tipo de ajuste, os moradores de Itaúnas desenvolveram uma série de outros ajustes para enfrentarem alguns problemas como no caso da sazonalidade, em virtude dos ciclos da natureza e do tipo de turismo que é desenvolvido no local.

Todas essas mudanças no território, vêm propiciando novas formas de relação dos moradores com o ambiente que os cercam, fazendo emergir territorialidades inéditas nesse ambiente. Observou-se, em Itaúnas, a coexistência de territorialidades distintas que se concretizam por meio de usos diversos: comunal tradicional, empresarial, comercial e governamental. Com isso, a população local, passa a criar e a incorporar novas concepções de uso, domínio e apropriação do território.

Com relação ao turismo, este se desenvolveu em grande escala no período entre 1996 a 2002, modificando a configuração espacial da Vila, introduzindo grande quantidade de pousadas e estabelecimentos comerciais e estratificando o espaço construído da Vila. 
Atualmente, o grande número de estabelecimentos comerciais e a crise do turismo que Itaúnas enfrenta, vem acarretando problemas de ordem econômica para os moradores nativos.

Quanto ao PEI, este ainda mantém uma relação de conflitos com os moradores locais, fruto do modelo sob o qual foi implantado. Com isso, constatou-se algumas ameaças a preservação dos ecossistemas e da biodiversidade local. Esse dilema entre Unidades de Conservação e populações locais se constitui em um grande desafio do século XXI. Faz-se necessário, diante de tal problemática, que em Unidades de Conservação a equipe envolvida na gestão ambiental seja tanto das ciências sociais quanto naturais, para que, de forma interdisciplinar, mantenham uma relação dialógica com a população humana do entorno e as que por algum motivo até hoje se encontram dentro, para que se tenha sucesso tanto na preservação da diversidade biológica como cultural.

Observou-se também, que mesmo sofrendo interferências no seu modo de vida, a população humana de Itaúnas, ainda conserva muitos saberes e apresenta algumas características da tradição local. Face a essa realidade, que refere-se às manifestações culturais ainda presentes em Itaúnas, evidencia-se a necessidade do desenvolvimento de projetos, ações e parcerias com empresas, como por exemplo a Aracruz celulose, a Petrobrás entre outras, para que se valorize, incentive e apoie tais manifestações culturais, o artesanato e os saberes e tradições locais. De certa forma, isso já vem acontecendo no cenário de Itaúnas, por meio de projetos de uma ONG, a Sociedade Amigos do Parque de Itaúnas em parcerias com tais empresas.

Nesse sentido, seria também interessante o desenvolvimento de um projeto pedagógico interdisciplinar, que envolva os conhecimentos, a sabedoria e as práticas tradicionais dentro do universo escolar.

Os conhecimentos construídos há muitas gerações pela população de Itaúnas, não têm sido valorizados principalmente pelos mais jovens. No entanto, uma vez considerados essenciais e trabalhados dentro das disciplinas como história, geografia, biologia etc, podem vir a fortalecer a cultura local, valorizando os conhecimentos empíricos sobre a natureza, a sabedoria e as práticas tradicionais. 
As questões acima expostas, permitem (re)pensar o processo educativo formal. Segundo Almeida ${ }^{5}$, a transmissão do conhecimento tem ocorrido de maneira mutilante e redutora. De um lado se tem o saber científico fracionado, não comunicante, e de outro, o saber tradicional, entendido como "popular", tratado como "filho bastardo" da aventura do conhecimento e excluído do âmbito da socialização e transmissão oficial.

Uma outra consideração é que estudando a população humana de Itaúnas, adotando-se como critério de classificação uma tipologia baseada na tecnologia de subsistência, ou seja, na tecnologia que os membros da sociedade usam para suprir as necessidades materiais da vida, pode-se diferenciá-la e classificá-la.

Desta forma, dentre os tipos de sociedades como a de caçadores-coletores; de horticultores simples e avançados; agrária simples e avançada, de pesca, marítimas, de pastoreio simples e avançadas e sociedades industriais (Kormondy \& Brown, 2002), pode-se afirmar que a população de Itaúnas constitui-se originalmente numa sociedade de pesca.

Entretanto, devido a forma sazonal em que a população realiza as atividades de subsistência, ao contato com outras sociedades urbano-industriais, bem como as novas necessidades de consumo, a sociedade de Itaúnas se constitui como uma sociedade híbrida. Isto pode ser constatado, uma vez que ainda tem como alicerce a atividade de pesca, porém intercalando tal atividade com aquelas ligadas ao turismo.

Outra observação a ser feita com relação a população humana de Itaúnas é que todas as características apresentadas pelos moradores quanto ao modos de produção, relações de parentesco e territorialidade e a forma de se relacionarem com o ambiente podem ser reveladas como processos adaptativos relevantes para a sobrevivência.

${ }^{5}$ ALMEIDA, M.C. Ciência e tradição: a régua e o compasso. Apresentado no $2^{\circ}$ Congresso Brasileiro de Emomatemática. Universidade Federal do Rio Grande do Norte 7 a 11 de abril, 2004. 
ANEXOS 


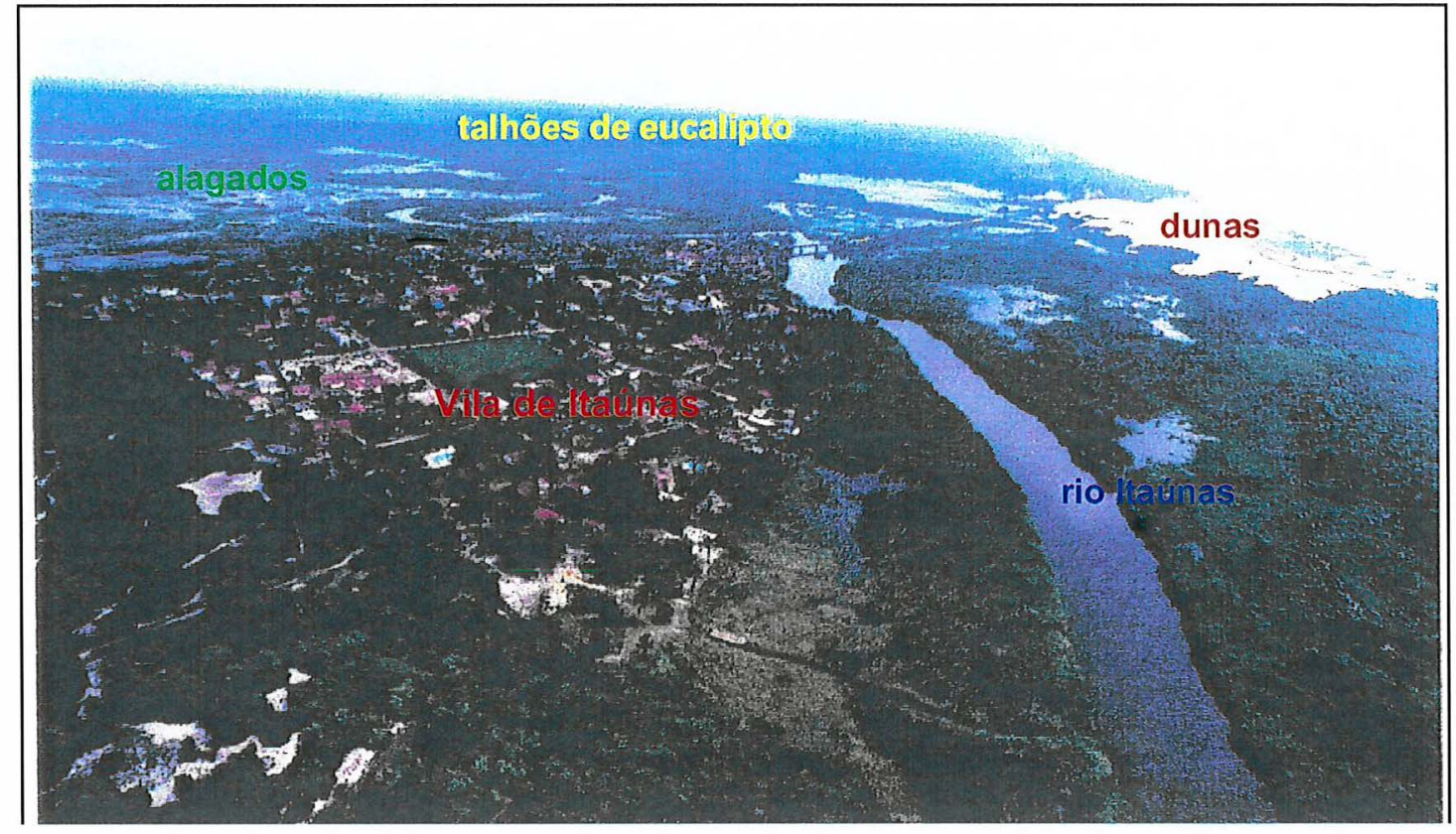

Figura 1 - Imagem aérea da área de pesquisa 


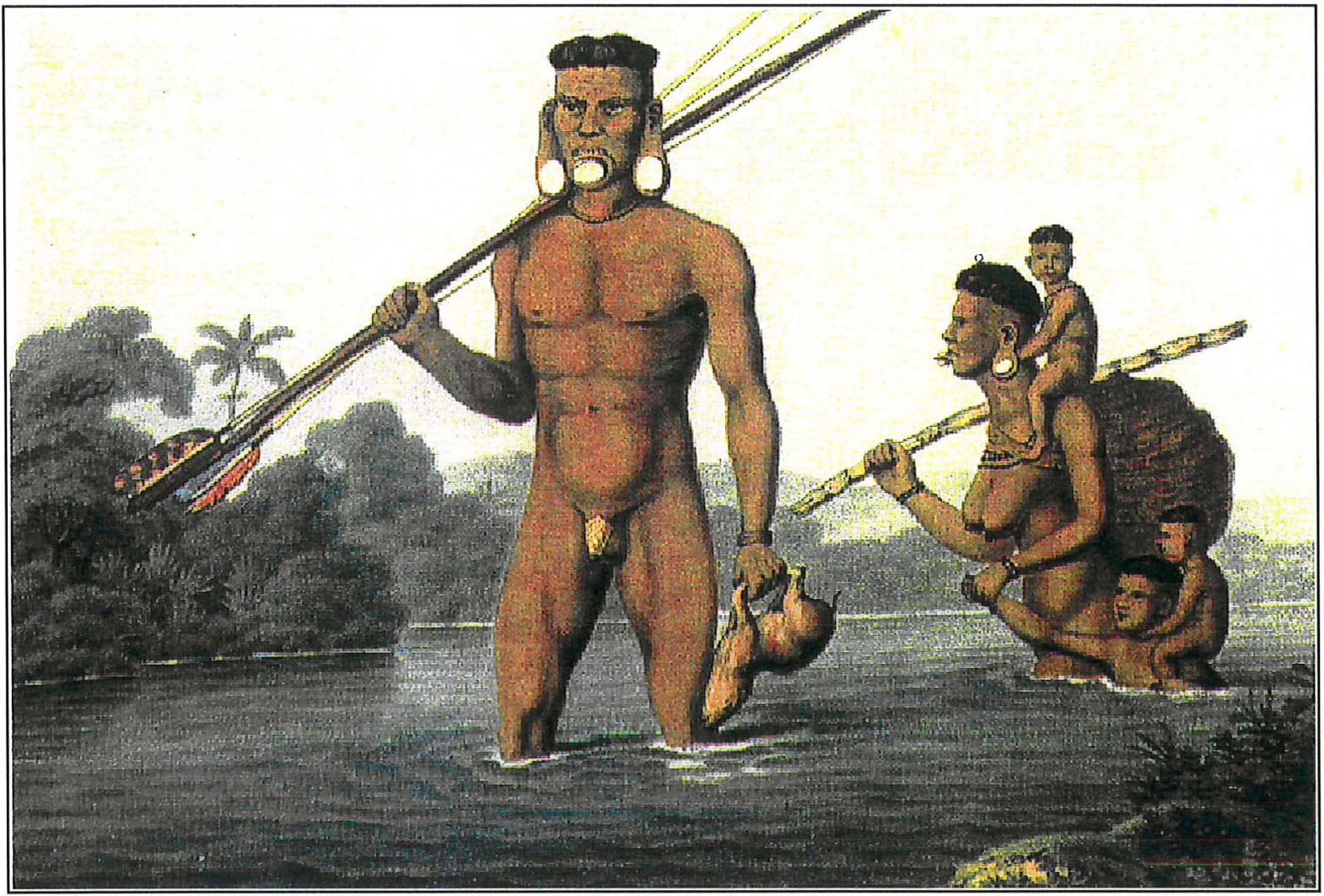

Figura 2 - Família de índios botocudos em viagem na região de Itaúnas - ES.

Fonte: Viagem ao Brasil, 2001. 


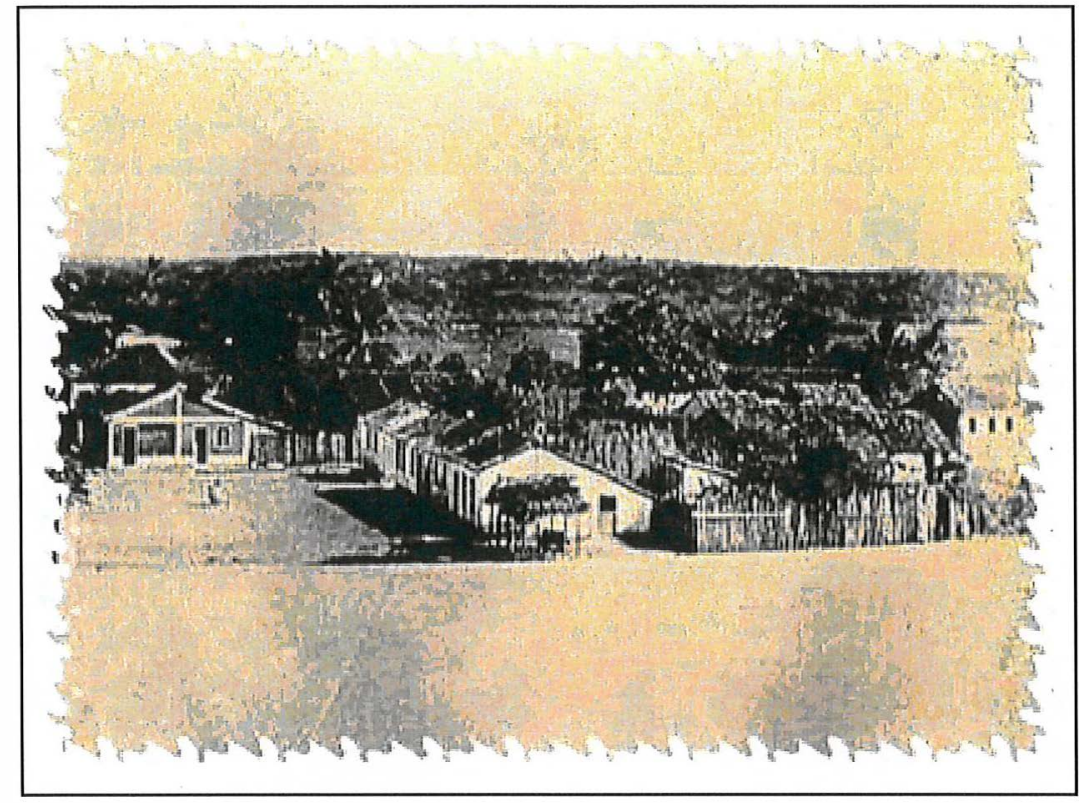

Figura 3 - Antiga vila de Itaúnas

Fonte: http://www.viladeitaunas.com.br

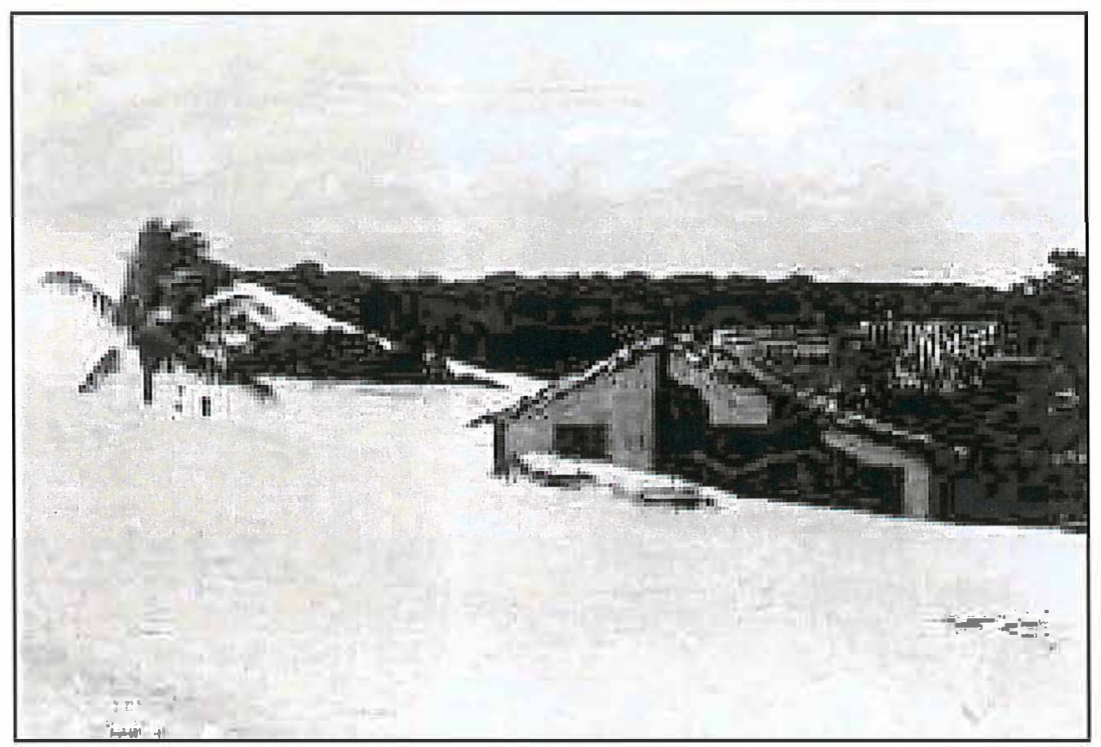

Figura 4 - Antiga Vila de Itaúnas, em processo de soterramento. Fonte: http://www.meubrfree.com.br/ itaunasforro/itasoter.jpg 

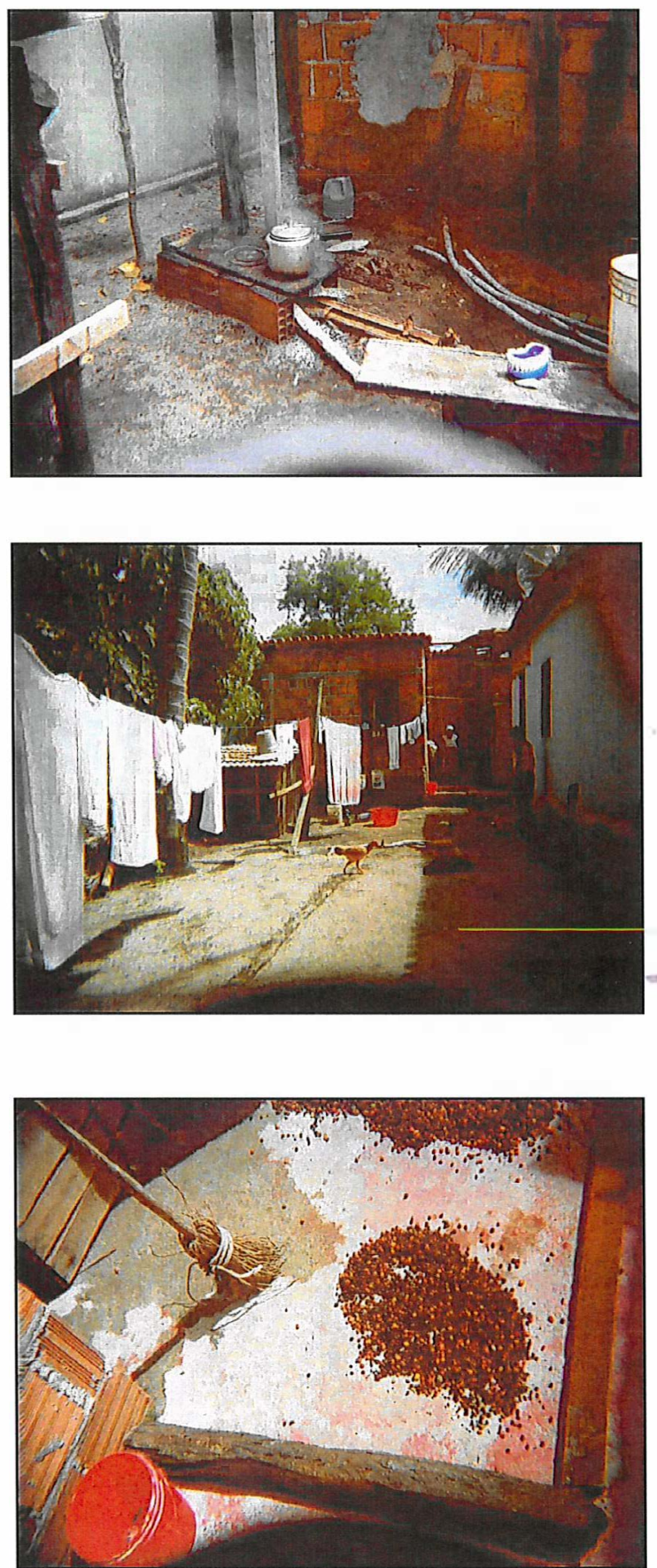

Figuras 5, 6 e 7 - Diferentes usos de quintais em Itaúnas Fotos: Julia Salvador Martins 


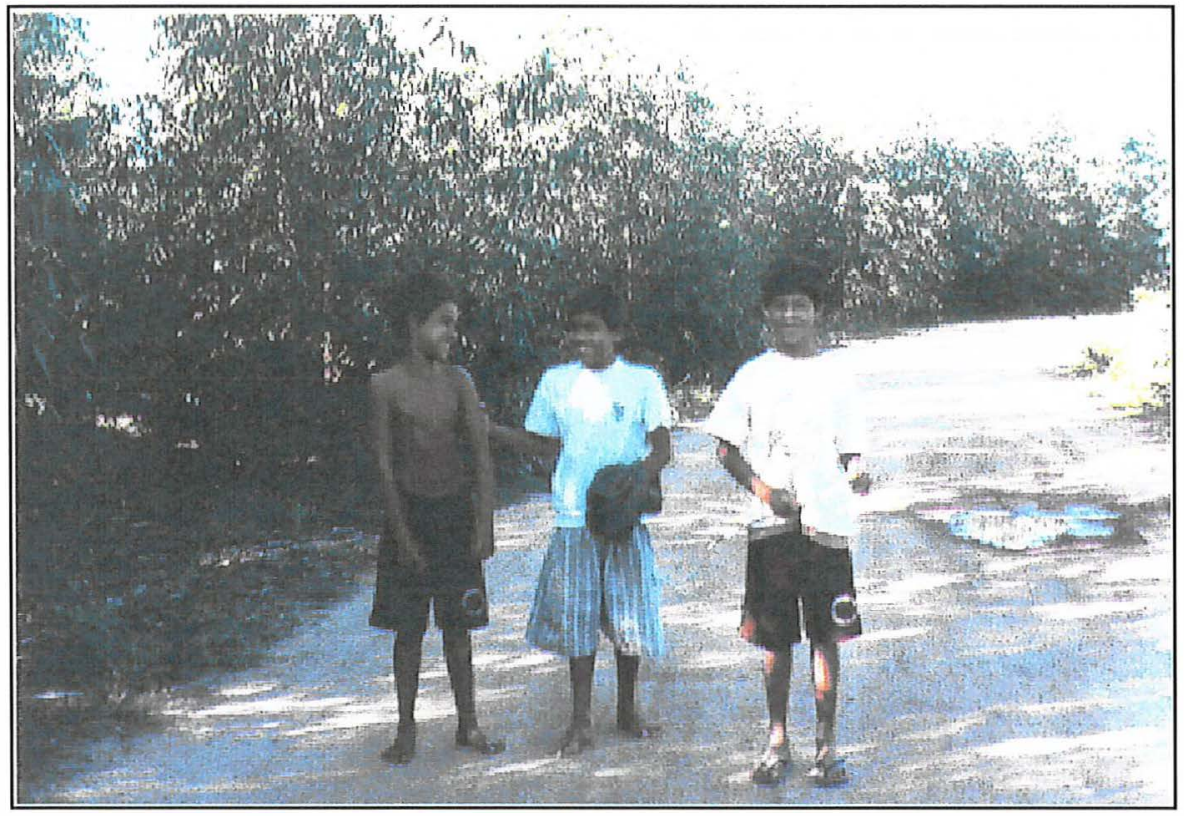

Figura 8 - Meninos de Itaúnas entre os talhões de eucalipto indo para roça do Angelin. Foto: Julia Salvador Martins

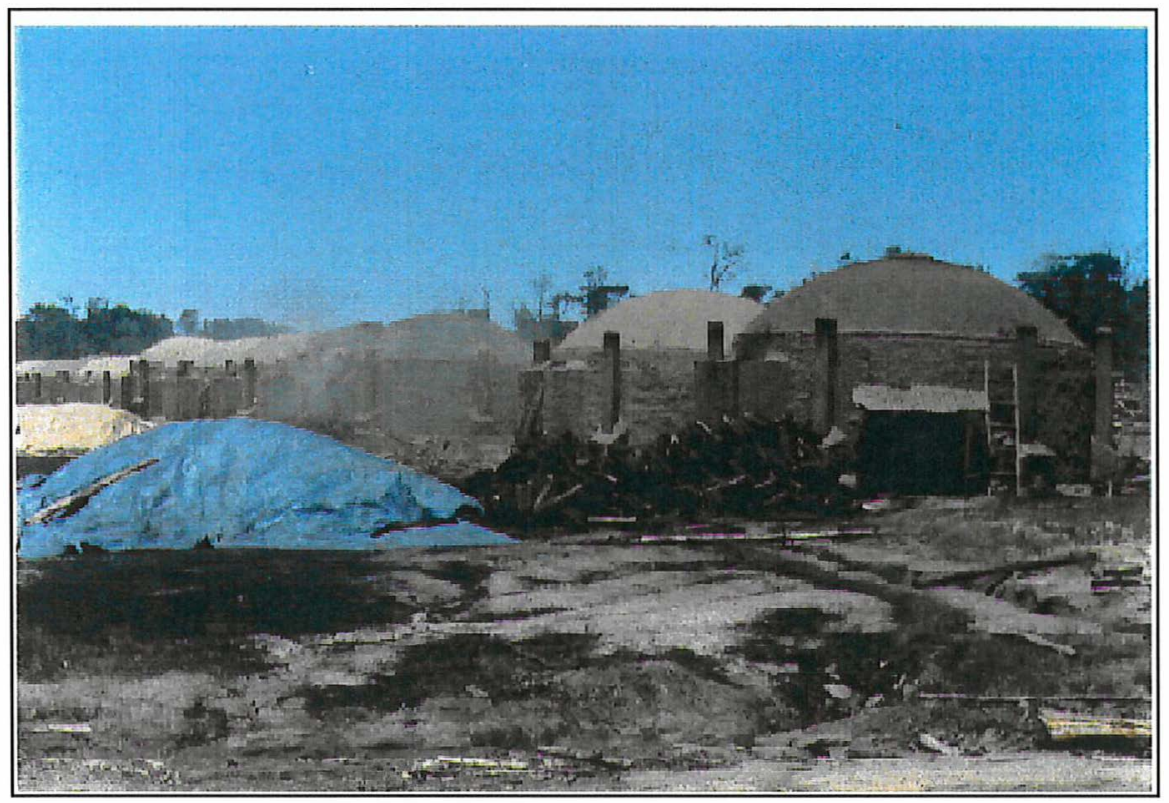

Figura 9 - Carvoaria na região de Itaúnas Foto: Flavia Rossi 


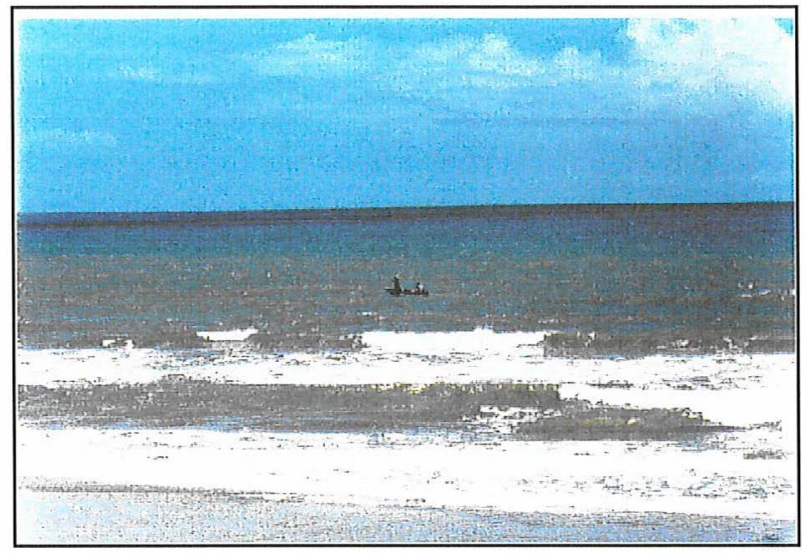

Figura 10 - Pescadores no mar, com canoa e remo Foto: Flavia Rossi
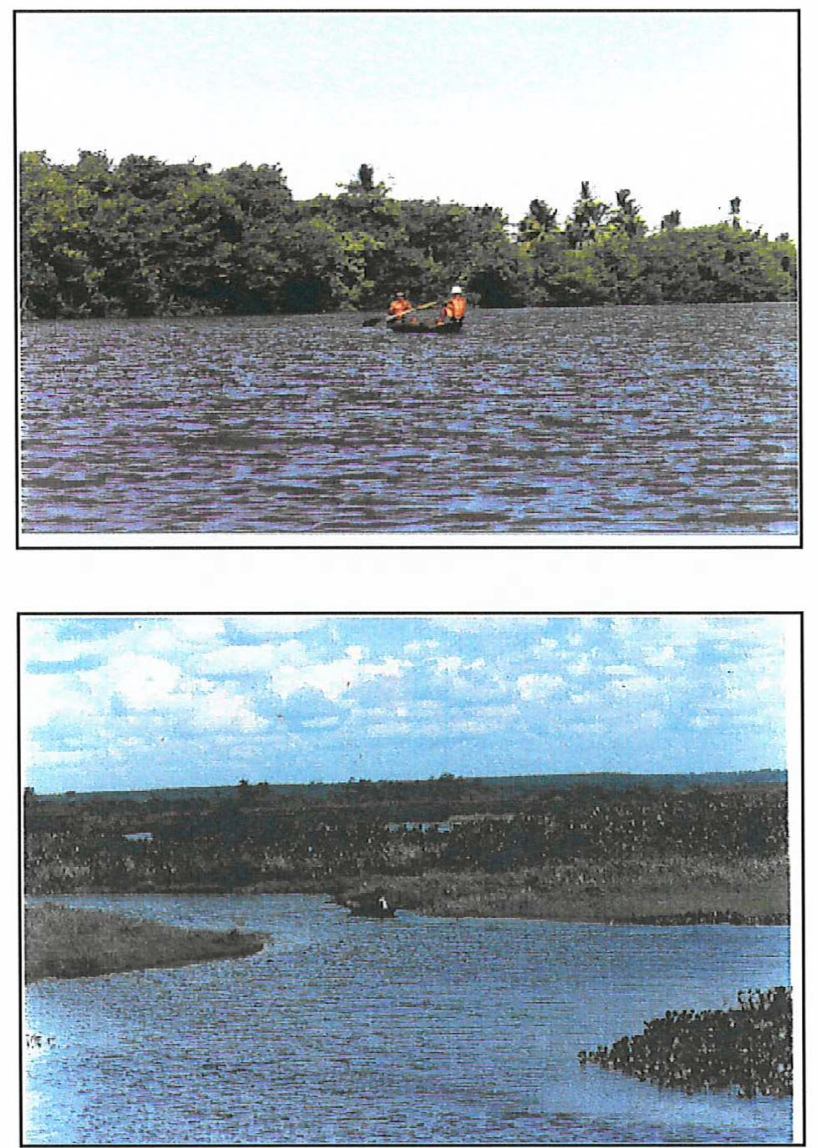

Figuras 11 e 12 - Pescadores no estuário e no rio de Itaúnas Foto: Flavia Rossi 

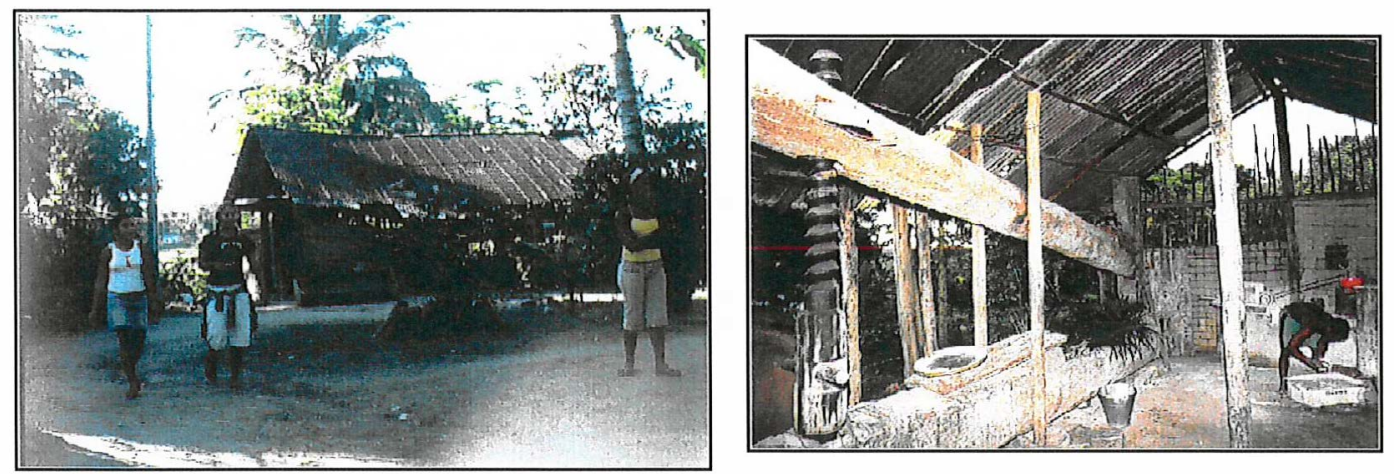

Figuras 13 e 14 - Casa de farinha no Angelin

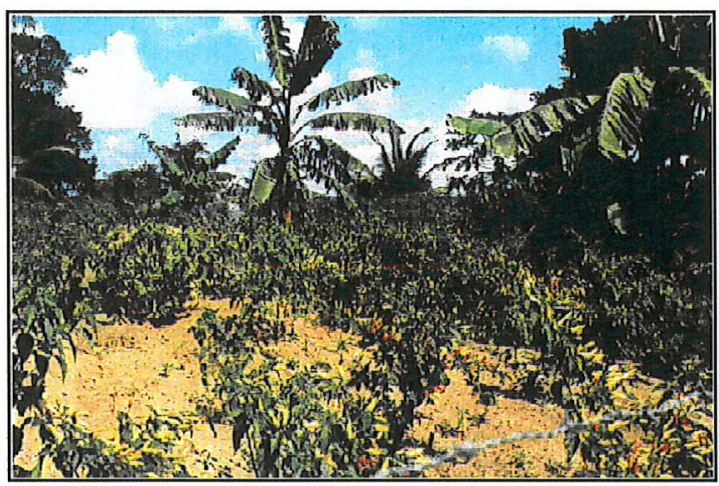

Figura 15 - Roça de pimenta no Angelin

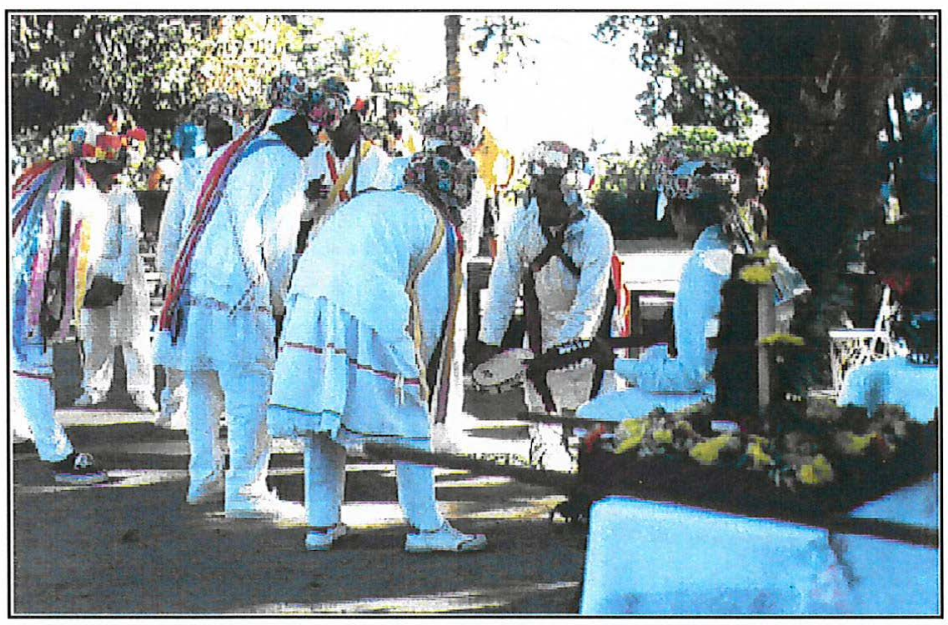

Figura 16 - Apresentação do Ticumbi na festa de Santa Clara no Angelin Fotos: Julia Salvador Martins 


\section{REFERÊNCIAS BIBLIOGRÁFICAS}

AB'SABER, A. Seminário internacional sobre eucalipto e seus impactos. Vitória:

Assembléia Legislativa do ES, 2001. 39p.

ACADEMIA DE CIÊNCIAS DO ESTADO DE SÃO PAULO: Conselho Nacional de Desenvolvimento Cientifico e Tecnológico; Fundação de Amparo ao Ensino do Estado de São Paulo. Glossário de ecologia. São Paulo, 1987. 271p.

ADAMS, C. Estratégias adaptativas de duas populações cablocas (Pará) aos ecossistemas de Várzea Estuarina e Estacional: uma análise comparativa. São Paulo, 2002. 373p. Tese (Doutorado) - Instituto de Biociências, Universidade de São Paulo.

ALMEIDA, M.C. Complexidade, do casulo a borboleta. In: CASTRO, G. (Org.). Ensaios de complexidade. 3.ed. Porto Alegre: Sulina, 2002. p. 21-41.

ANDRADE, M. Territorialidades, desterritorialidades, novas territorialidades: os limites do poder nacional e do poder local. In: SANTOS, M.; SILVEIRA, M.A. (Org.). Território, globalização e fragmentação. 5.ed. São Paulo: Editora Hucitec, 2002. p.213-220.

ARACRUZ CELULOSE. Relatório anual 2003. http// www.aracruz.com.br (20 out. 2004).

ARRUTI, J.M.; DE’NADAI, A. Para entender a expropriação de terras quilombolas. http// www.koinonia.org.br (07 maio 2004). 
ARRUDA, R.S.V. Populações tradicionais e a proteção dos recursos naturais em unidades de conservação. In: CONGRESSO BRASILEIRO DE UNIDADES DE CONSERVAÇÃO, 1., Curitiba, 1997. Anais. Curitiba: 1997. p.261-275.

BEGOSSI, A. Ecologia humana: um enfoque das relações homem-ambiente.

Interciências, v.18, n.3, p.121-132, 1993.

BEGOSSI, A; CASTRO, F.; SILVANO, R. Ecologia humana e conservação. In:

BEGOSSI, A. (Org.). Ecologia de pescadores da Mata Atlântica e da Amazônia.

São Paulo: Hucitec; Unicamp; USP, Nupaub; FAPESP, 2004. p.313-324.

BOFF, L. Saber ambiental: ética do humano. 7.ed. Petrópolis: Vozes, 1999. 199p.

CALDEIRON, S.S. Recursos naturais e meio ambiente: uma visão do Brasil. Rio de Janeiro: IBGE, 1993. 154p.

CAMPOS, N.J. Terras de uso comum no Brasil: um estudo sobre suas diferentes formas. São Paulo, 2000. 225p. Tese (Doutorado) - Faculdade de Filosofia, Letras e Ciências Humanas, Universidade de São Paulo.

CÂNDIDO, A. Os parceiros do Rio Bonito. 8.ed. São Paulo: Livraria Duas Cidades, 1998. 284p.

CAPRA, F. O ponto de mutação. Trad. de A. Cabral. São Paulo: Editora Cultrix, 1982. $447 p$.

CARDOSO, E.S. Pescadores artesanais: natureza, território e movimento social. São Paulo, 2001. 136p. Tese (Doutorado) - Faculdade de Filosofia, Letras e Ciências Humanas, Universidade de São Paulo. 
CARVALHO, H.C.B. Artesanato de caixeta em São Sebastião-SP. Piracicaba, 2001. 143p. Dissertação (Mestrado) - Escola Superior de Agricultura "Luiz de Queiroz", Universidade de São Paulo.

CASTRO, F. Níveis de decisão e o manejo de recursos pesqueiros. In: BEGOSSI, A. (Org.). Ecologia de pescadores da Mata Atlântica e da Amazônia. São Paulo: Hucitec; Unicamp; USP/Nupaub; FAPESP, 2004. p.255-284.

CHAVEZ, M.G.G. Biodiversidade e conhecimento local: do discurso à prática baseada no território. In: ENCONTRO NACIONAL DE PÓS-GRADUAÇÃO E PESQUISA EM AMBIENTE E SOCIEDADE. 1., Campinas, 2002. http:// www.scielo.org (28 nov. 2003).

COIMBRA, U. Aracruz Celulose, a besta do apocalipse, cresceu. Século Diário, Vitória, 2002. http// www.seculodiario.com.br (28 ago. 2004).

COMISSÃO MUNDIAL SOBRE MEIO AMBIENTE E DESENVOLVIMENTO. Nosso futuro comum. 2.ed. Rio de Janeiro: Fundação Getúlio Vargas, 1991. 430p.

CORRÊA, R.L. Territorialidade e corporação: um exemplo. In: SANTOS, M.; SILVEIRA, M.A. Território, globalização e fragmentação. 5.ed. São Paulo: Editora Hucitec - Anpur, 2002. p.252- 256.

COSTA, S.M. As redes de pesca: estratégias econômicas e formas de solidariedade entre os pescadores artesanais. Viçosa, 1999. 158p. Dissertação (Mestrado) - Universidade Federal Viçosa.

DIAS, C. Estudo de caso idéias importantes e referências. http:// www.geocities.com/claudiaad/publicacoes.html (08 de jan. 2004a) 
DIAS, C. Pesquisa qualitativa - características gerais e referências. http:// www.geocities.com/claudiaad/publicacoes.html (08 de jan. 2004b)

DIEGUES, A.C.S. População tradicional em unidades de conservação. São Paulo: USP, NUPAUB, 1993. 178p.

DIEGUES, A.C.S. Povos e mares: leituras e sócio-antropologia marítima. São Paulo: USP, NUPAUB, 1995. 269p.

DIEGUES, A.C.S. Ecologia humana/planejamento em áreas.costeiras. São Paulo: USP, NUPAUB, 1996a. 155p.

DIEGUES, A.C.S. O mito moderno da natureza intocada. São Paulo: USP, NUPAUB, 1996b. 161p.

DIEGUES, A.C.S. Áreas naturais protegidas, o turismo e as populações tradicionais. In: SERRANO, C.M.T; BRUHNS, H.T. Viagens a natureza: turismo, cultura e ambiente. Campinas: Papirus, 1997. p.85-102.

DIEGUES, A.C.S. Etnoconservação da natureza: enfoques alternativos. In: DIEGUES, A.C.S. (Org.). Etnoconservação: novos rumos para a natureza. São Paulo; Hucitec; USP, NUPAUB, 2000. p.01-46.

DIEGUES, A.C.S. Repensando e recriando formas de apropriação comum dos espaços e recursos naturais. In: DIEGUES, A.C.S.; MOREIRA, A.C.C. (Org.). Espaços e recursos naturais de uso comum. São Paulo: USP, NUPAUB, 2001. p.44-61.

DIEGUES, A.C.S. (Org.). Povos e águas: inventário de áreas úmidas brasileiras. 2.ed. São Paulo: USP, NUPAUB, 2002. 597p. 
DIEGUES, A.C.S.; NOGARA, P. O nosso lugar virou Parque: um estudo sócioambiental do saco de Mamanguá-RJ. São Paulo: USP, NUPAUB, 1994. 181p.

FARIA, I.F. Hotéis de selva e novas territorialidades no Amazonas. In: FARIA, I.F. Turismo: sustentabilidade e novas territorialidades. Manaus: Editora da Universidade do Amazonas, 2001. p.115-127.

FEENY, D.; BERKES.F.; MAC LAY, B. J.; ANCHESON, J.M. A tragédia dos comuns: vinte e dois anos depois. In: DIEGUES, A.C.S.; MOREIRA, A.C.C. (Org.). Espaços e recursos naturais de uso comum. São Paulo: USP, NUPAUB, 2001. p.17-42.

FERREIRA, S.R.B. Da fartura à escassez: a agroindústria de celulose e o fim dos territórios comunais no extremo norte do Espírito Santo. São Paulo, 2002. 204p. Dissertação (Mestrado) - Faculdade de Filosofia, Letras e Ciências Humanas, Universidade de São Paulo.

FERREIRA, L.C. Dimensões humanas da biodiversidade: mudanças sociais e conflitos em torno de áreas protegidas no Brasil. In: SIMPÓSIO DE ETNOBIOLOGIA E ETNOECOLOGIA DA REGIÃO SUL, 1,. Florianópolis, 2003. Anais. Florianópolis: Sociedade Brasileira de Etnobiologia e Etnoecologia.

FOLEY, R. Apenas uma espécie única. São Paulo: Atheneu Editora, 1993. 563p.

FREIRE, R.M. Sistemas locais de apropriação de recursos e suas implicações para projetos de manejo comunitário: um estudo de caso numa comunidade tradicional da floresta Nacional do Tapajós. Piracicaba, 2001. 137p. Dissertação (Mestrado) - Escola Superior de Agricultura “Luiz de Queiroz”, Universidade de São Paulo. 
GALVEAS, P.A.O.; BRITTO, R.A; DONATTI, J.M. BARBOSA, C.A. Plano estratégico da agricultura capixaba: estudo temático. Silvicultura, v. 10, out. 2003. http//www.seama.gov.br (12 set. 2004)

GARROTE, V. Os quintais caiçaras, suas características sócioambientais e perspectivas para a comunidade do Saco do Mamanguá, Paraty-RJ. Piracicaba, 2004. 179p. Dissertação (Mestrado) - Escola Superior de Agricultura "Luiz de Queiroz", Universidade de São Paulo.

GIARETTA, M. J. Turismo da juventude. São Paulo, 2002. 119p. Tese (Doutorado) Escola de Comunicação e Artes, Universidade de São Paulo.

GIL, A.C. Métodos e técnicas de pesquisa social. 5.ed. São Paulo: Atlas, 1999. 206p.

GONSALVEZ, M.A.O valor da afinidade: parentesco e casamento entre os Pirahã. Revista de Antropologia, v.40, n.1, 1997. http:// www.scielo.org (14 out. 2003)

\section{GOVERNO DO ESTADO DO ESPIRITO SANTO DO ESPIRITO SANTO.}

Fundamentos para a elaboração do plano de ordenamento da Vila de ItaúnasES. Vitória, 2001. (Relatório Preliminar)

GUIMARÃES, R.G. A um passo: o conhecimento etnoecológico e a promessa da ciência relevante. In: SIMPÓSIO DE ETNOBIOLOGIA E ETNOECOLOGIA DA REGIÃO SUL, 1., Florianópolis, 2003. Anais. Florianópolis: Sociedade Brasileira de Etnobiologia e Etnoecologia, 2003. p. 79-94.

HAESBAERT. R. Territórios alternativos. Niterói: Editora UFF; São Paulo: Contexto, 2002. 173p. 
HAGUETTI, T.M. Metodologias qualitativas na sociologia. Rio de Janeiro: Vozes, 1992. 224p.

HARDIN, G. The Tragedy of the Commons. Science, n.162, p.1343-1348, 1968.

IGNARRA, L.R. Fundamentos do turismo. 2.ed. São Paulo: Pioneira Thomson Learning, 2000.135p.

KORMONDY, E.; BROWN, D. Ecologia humana. São Paulo: Atheneu Editora, 2002. $503 p$.

KUHN, T.S. A estrutura das revoluções científicas. Trad. de B.V. Boeira e N. Boeira. São Paulo: Editora Perspectiva, 1975. 254p.

LAPLATINE, F. Aprender antropologia. Trad. de M.I. Chauvel. São Paulo: Brasiliense, 1999. 201p.

LEFF, H. Saber ambiental: sustentabilidade, racionalidade, complexidade e poder. Trad. de L.M.E. Orth. Petrópolis: Vozes, 2001. 343p.

LÉVI-STRAUSS, C. Antropologia estrutural II. Trad. de M.C. Pandolfo. Rio de Janeiro: Tempo Brasileiro, 1973.363p.

LÉVI-STRAUSS, C. O pensamento selvagem. Campinas: Papirus, 1997. 323p.

LITTLE. P.E. Territórios sociais e povos tradicionais no Brasil: por uma antropologia da territorialidade. Série Antropologia n.322, Brasília, 2002. http// www. unb/ics/dar/serie322empdf.pdf (09 set. 2004). 
LUCHIARI, M.T.D.P. Turismo e ambiente na mitificação dos lugares. In: FARIA, I.F. (Org.). Turismo: sustentabilidade e novas territorialidades. Manaus: Editora da Universidade do Amazonas, 2001. p.17-29.

MALDONADO, S.C. Pescadores do mar. São Paulo: 1996. 77p.

MARCONI, M.A.; LAKATOS, E..M. Técnicas de pesquisa: planejamento e execução de pesquisas, elaboração, análises e interpretação de dados. 4.ed. São Paulo: Atlas, 1999. 260p.

MARTINS, J.S. Expropriação e violência: a questão política no campo. 3.ed. São Paulo: Hucitec, 1991.

MESQUITA, Z. Território a consciência territorial. In: MESQUITA, Z. e BRANDÃO, O.C.R. Territórios do cotidiano: uma introdução a novos olhares e experiências. Porto Alegre: Editora Universidade/UFRGS; Santa Cruz do Sul: Universidade de Santa Catarina do Sul, 1995. p.76-92.

MIGLIANO, A.B. Amazônia: interações ecológicas e estratégias adaptativas dos cablocos do Médio Solimões. São Paulo, 2000. 183p. Dissertação (Mestrado) Instituto de Biociências, Universidade de São Paulo.

MINAYO, M.C.S. (Org.). Pesquisa social. Teoria, método e criatividade. Petrópolis: Vozes, 1994. 67p.

MORA, L.E; GARCIA, A. A cultura do eucalipto no Brasil. São Paulo: Sociedade Brasileira de Silvicultura, 2000. 115p.

MORÁN, E.F. A ecologia humana das populações humanas da Amazônia. Petrópolis: Vozes, 1990.367p. 
MORÁN, E.F. Adaptabilidade humana: uma introdução a antropologia ecológica. São Paulo: EDUSP, 1994. 430p.

MORIN, E. Ciência com consciência. Trad. de M.D. Alexandre e M.A.S. Dória. Rio de Janeiro: Bertrand Brasil, 1996. 336p.

MORIN, E. Os sete saberes necessários a educação do futuro. Trad. de C.E.F.da Silva e J. Sawaya. 2.ed. São Paulo: Cortez; Brasília: UNESCO, 2000. 118p.

MORIN, E. Complexidade e ética da solidariedade. In: CASTRO, G. Ensaios de complexidade.2.ed. Porto Alegre: Sulina, 2002. p. 11-20.

MORIN, E.; KERN, A.B. Terra-pátria. Trad. de A.P.da Silva. 2.ed. Lisboa: Instituto Piaget, 2001. 209p.

NEVES, G.S. Folclore brasileiro: Espírito Santo. Rio de Janeiro: Ministério da Educação e Cultura; FUNARTE, 1978. 77p.

OSTROM, E. Reformulando a teoria sobre o uso comum de recursos. Ambiente e Sociedade, v.5, n.10, p.5-25, jan./jun. 2002. http:// www.scielo.org (25 jan. 2004).

PASSOS, M. O catolicismo popular: o sagrado, o popular, a tradição e a festa. In: PASSOS, M. (Org.). A festa na vida: significados e imagens. Petrópolis: Vozes, 2002. p.165-190.

PETROFF, M.A.D.S. Levantamento dos rapinantes do Parque Estadual de Itaúnas e os impactos das atividades sócio-econômicas. São Paulo, 2003. 78p. Dissertação (Mestrado) - Instituto de Psicologia, Universidade de São Paulo. 
PEZZUTTI, J. Tabus alimentares. In: BEGOSSI, A. (Org.). Ecologia de pescadores da Mata Atlântica e da Amazônia. São Paulo: Hucitec; Unicamp; USP, NUPAUB; FAPESP, 2004. p.167-186.

PRIMACK, R.B.; RODRIGUES, E. Biologia da conservação. Londrina: E. Rodrigues, 2001.327p.

RAFFESTIN, C. Por uma geografia do poder. Trad. de M.C. França. São Paulo: Editora Ática, 1993. 226p.

REBELLO, W.S.; FOËGER, T.J. A implantação do Parque Estadual de Itaúnas/ES e os impactos sócio-ambientais. In: ENCONTRO NACIONAL DE GEÓGRAFOS, 13., João Pessoa, 2002. (compact disc).

RELPH, E.C. As bases fenomenológicas da geografia. Geografia, vol.4, n.7, p.1-25, abr., 1979.

REZENDE, C.F. Ecoturismo como instrumento de desenvolvimento: limites, desafios e potencialidades. Lavras, 2004. 115p. Dissertação (Mestrado) - Universidade Federal de Lavras.

RIBEIRO NETO, F. As estratégias de sobrevivência de comunidades litorâneas em regiões ecologicamente degradadas: o caso da Baixada Santista. Piracicaba: ESALQ, 1989. (Relatório de Pesquisa)

ROCHA, S.B. Unidades de conservação e populações tradicionais: uma visão conservacionista. In: CONGRESSO BRASILEIRO DE UNIDADES DE CONSERVAÇÃO, 1., Curitiba, 1997. Anais. Curitiba: 1997. p. 277-292. 
RODRIGUES, A.M. A produção e o consumo do espaço para o turismo e a problemática ambiental. In: YAZIGI, E. Turismo-espaço, paisagem e cultura. São Paulo: Hucitec, 1996. p. 55-62.

SANTANA, E.M.V. Turismo: importância e características de seus consumidores no município de Viçosa. Viçosa, 1996. 116p. Dissertação (Mestrado) - Universidade Federal de Viçosa.

SANTOS, B.S. O mundo resiste. Revista Caros Amigos, n.78, p.34-38, set. 2003.

SANTOS, B.S. Um discurso sobre as ciências. São Paulo: Cortez, 2003. 92p.

SERRANO, C.M.T. A vida e os parques: proteção ambiental, turismo e conflitos de legitimidade em unidade de conservação. In: SERRANO, C.M.; BRUHNS, H.T. Viagens a natureza: turismo, cultura e ambiente. Campinas: Papirus, 1997. p.103124.

SERVICE, E.R. The hunthers. New Jersey: Prentice-Hall, 1966. 148p.

SILVA, A.J.P. A capuera e a arte da capueragem: ensaio socioetimológico. Salvador: Empresa Gráfica da Bahia, 2003. 119p.

SILVA, J.M. Ações estratégicas para o turismo no município de Lavras-MG. Lavras, 2003. 167p. Dissertação (Mestrado) - Universidade Federal de Lavras.

SILVA, M.R. Povos de terra e água: a comunidade pesqueira "Canto do Mangue", Canguaretama-RN. Piracicaba, 2004. 109p. Dissertação (Mestrado) - Escola Superior de Agricultura “Luiz de Queiroz”, Universidade de São Paulo. 
SILVANO, R. Ecologia das comunidades de pescadores do rio Piracicaba-SP. Campinas, 1997. 157p. Dissertação (Mestrado) - Instituto de Biologia, Universidade Estadual de Campinas.

SILVANO, R. Pesca artesanal e etnoictiologia. In: BEGOSSI, A. (Org.). Ecologia de pescadores da Mata Atlântica e da Amazônia. São Paulo: Hucitec; Unicamp; USP, NUBAUB; FAPESP, 2004. p. 187-222.

SIMÃO, C.G. Áreas cultivadas na comunidade do Cachoeira do Guilherme, na Estação Ecológica Juréia-Itatains, SP. Piracicaba, 2003. 124p. Dissertação (Mestrado) - Escola Superior de Agricultura “Luiz de Queiroz", Universidade de São Paulo.

\section{SUZANO BAHIA SUL PAPEL E CELULOSE. Relatório anual 2004.}

http//www.suzano.com.br (29 de jun. 2004).

TRIVIÑOS, A.N.S. Introdução à pesquisa em ciências sociais: a pesquisa qualitativa em educação. São Paulo: Atlas, 1987. 175p.

VIERTLER, R.B. Métodos antropológicos como ferramentas para estudos em etnobiologia e etnoecologia. In: AMOROZZO, M.C.M; MING, L.C.; SILVA, S.P. (Org.). Métodos de coleta e análise de dados em etnobiologia, etnoecologia e disciplinas correlatas. Rio Claro: UNESP, CNPq; Coordenadoria de Área de Ciências Biológicas, 2002. p. 11-29.

VIAGEM AO BRASIL DO PRÍNCIPE MAXIMILIANO DE WIED-NEWIED. Petrópolis: Kapa Editorial, 2001. 217p. (Biblioteca Brasiliana da Roseito Bosch Gmbl).

WILSON. E.O. Da natureza humana. São Paulo: EDUSP e Editora T. A. Queiroz, 1981. 263p. 